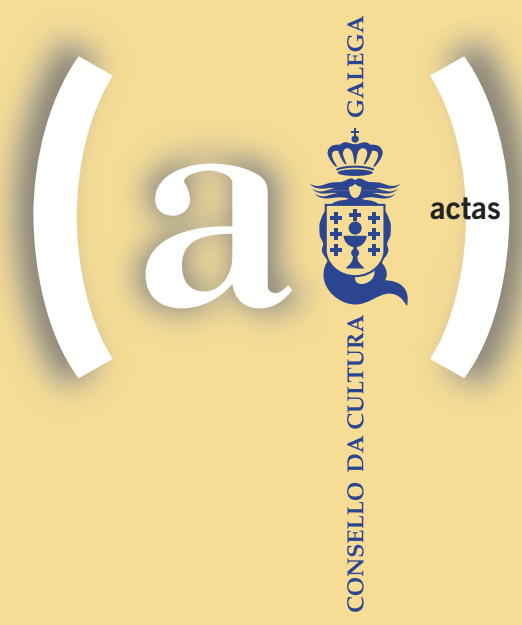

FRANCISCO DÍAZ-FIERROS VIQUEIRA
COORDINADOR

B. J. Feijoo, renovador do pensamento da Ilustración

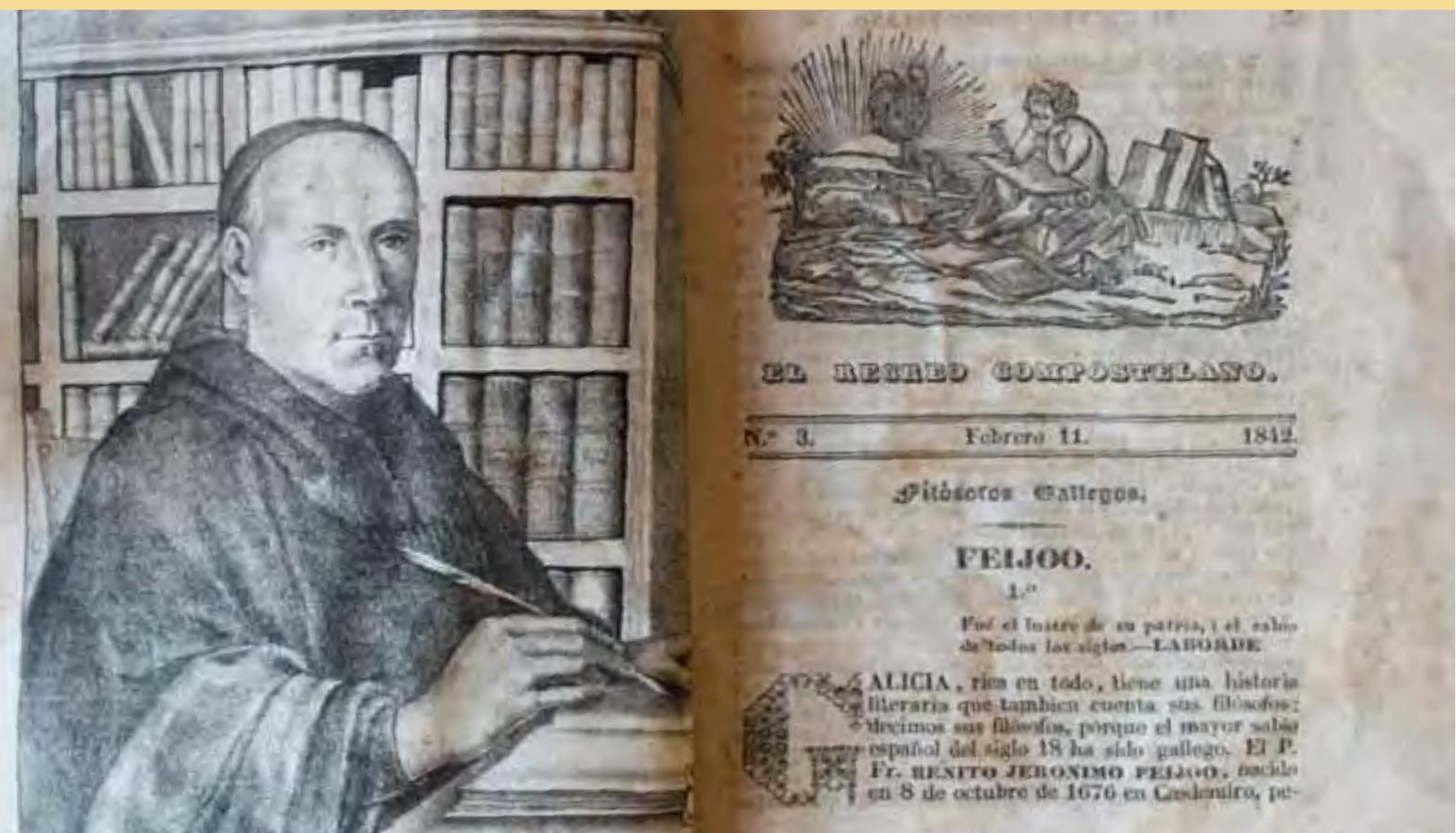






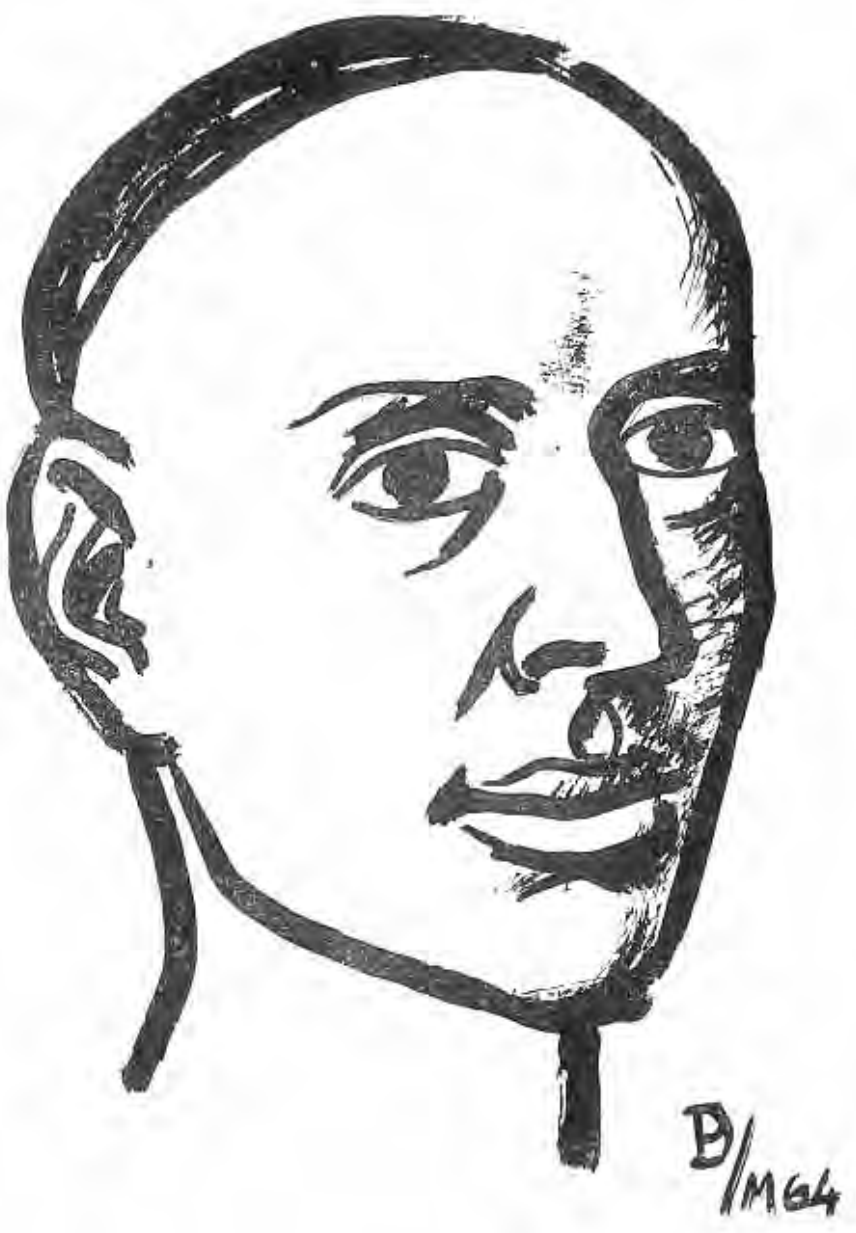

Retrato de Feijoo por Díaz Pardo para o libro en homenaxe a Feijoo, publicado en 1967 pola Universidad Nacional de La Plata (Arxentina). 


\section{B. J. Feijoo, renovador do pensamento da Ilustración}




\section{Edita}

(c) CONSELLO DA CULTURA GALEGA, 2016

Pazo de Raxoi $\cdot 2^{0}$ andar - Praza do Obradoiro

$15705 \cdot$ Santiago de Compostela

T $981957202 \cdot$ F 981957205

corre0@consellodacultura.org

www.consellodacultura.org

\section{Proxecto gráfico}

Imago Mundi Deseño

Imprime

Grafisant, S.L.

Depósito Legal: C 988-2016

ISBN 978-84-92923-73-1 


\section{FRANCISCO DÍAZ-FIERROS VIQUEIRA}

COORDINADOR

B. J. Feijoo, renovador do pensamento da Ilustración

Actas do seminario realizado en Ourense o día 9 de outubro de 2014, no 250 aniversario do seu pasamento (1676-1764) 
Limiar 
ai unha opinión practicamente unánime sobre a pegada
que deixou a Ilustración na cultura española a partir da
segunda metade do século xvıII. Pénsese, dunha banda,
na aceleración do tempo histórico e, doutra, no peche
paulatino da fenda cultural que se estaba a xerar entre España e o resto dos países europeos grazas ao alento renovador e ás realizacións que se puxeron en marcha.

Institucións tradicionais como o Exército, a Igrexa ou as universidades iniciaron un novo camiño. Nel, as correntes renovadoras do pensamento atoparon acubillo e outras entidades, como as Sociedades Económica de Amigos do País, actuaron como punta de lanza deste movemento que cambiou a face do país e soubo abrir as súas fronteiras ao intercambio cultural con outros Estados, nomeadamente Francia.

Á xeración que foi protagonista destas realizacións precedeulle outra, denominada "crítica», que tivo o papel fundamental de se enfrontar abertamente coas vellas crenzas e tradicións. Estaba formada, principalmente, por uns cantos persoeiros que, armados soamente coa súa pluma e a súa clarividencia, principiaron unha dura campaña de descualificación dos erros de pensamento e dos costumes máis atrasados do país. Malia seren rexeitados por moitos, o seu arduo traballo axudou a abrir as portas a un novo xeito de entender o mundo e, sobre todo, conseguiron que os seus escritos comezasen a ser lidos por un maior número de españois.

Benito Jerónimo Feijoo, o Padre Mestre, foi un deles. Quizais sexa o máis lido de todos, pois o seu Teatro crítico e as súas Cartas eruditas chegaron a ser auténticos best-sellers do seu tempo e o seu nome mesmo chegou a ser un símbolo do progreso e da nova cultura. De todas as maneiras, despois da Guerra da Independencia e, sobre todo, do reinado de Fernando VII, caeu no esquecemento. A morte do monarca, en 1833, non lle deparou mellor fortuna, porque ata ben 
entrada a segunda metade do século non volveron ser editados os seus traballos. Con todo, o recońecemento definitivo deste intelectual veu coa conmemoración do centenario do seu nacemento no último cuarto de século XIX.

Galicia e, nomeadamente, a cidade de Ourense distinguíronse dun xeito moi singular por espallar por todo o país o pensamento de bieito, ata o punto de que na segunda metade do XIX as publicacións galegas superaron en importancia as do resto de Espańa. A figura de Feijoo foi aclamada e a súa galeguidade converteuse en motivo de orgullo e satisfacción para unha Galicia que comezaba a desangrarse nunha riada humana sen fin cara ao alén mar. Esta corrente de afecto mantívose, cando menos, ata a segunda metade do século xx, na que outras efemérides vitais do beneditino serviron como xustificación para realizar novos estudos sobre o seu pensamento e a súa importancia no contexto cultural español. De todas as maneiras, no último cuarto do século xx e na primeira década do XxI comezou a caer nun lento e progresivo esquecemento, e foron moi escasos os traballos ou mencións que lle foron dedicados pola intelectualidade galega.

Feijoo, a pesar de todo, segue a ser unha figura esencial e indiscutible da nosa historia cultural que está por riba das modas e dos oportunismos intelectuais do momento. Por iso, o Consello da Cultura Galega non quixo deixar pasar os douscentos cincuenta anos do seu pasamento, en 1764, sen lle lembrar á cidadanía galega que o erudito ourensán segue a ser un dos máximos referentes da nosa cultura, como recońeceu Castelao na «Alba de Groria» incluíndoo no cortexo dos galegos egrexios e inmorredoiros.

Isto aconteceu o 9 de outubro de 2014, cando se desenvolveu na cidade Ourense (non podía ser noutro sitio) unha xornada de estudo sobre aspectos, aínda non ben tratados sobre a vida e a obra do beneditino de Casdemiro e que agora son recollidos nesta publicación. Deste xeito, quérese contribuír ao avivamento entre nós da memoria dun galego, referente fundamental da Ilustración española e loitador incansable contra o pensamento débil, preguizoso e lixeiro. Algo que nunca deixará de estar de actualidade.

\section{Francisco Díaz-Fierros Viqueira}





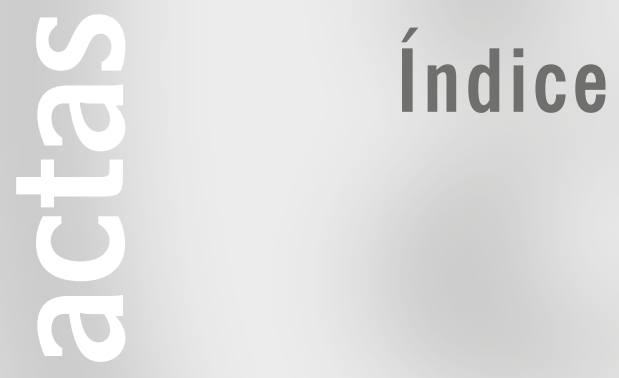




\section{LIMIAR}

Francisco Díaz-Fierros Viqueira

13 «Veritas temporis filia»: a achega de Feijoo á historia cultural Inmaculada Urzainqui

37 Vixencia actual do prensamento xurídico-social do Padre Feijoo Luis Rodríguez Ennes

53 Ollada crítica sobre a obra de Feijoo de dúas intelectuais galegas: Concepción Arenal e Emilia Pardo Bazán

Xosé Ramón Barreiro Fernández

75 Presenza do Padre Feijoo en Galicia Francisco Díaz-Fierros Viqueira 

"VERITAS TEMPORIS FILIA»:

A ACHEGA DE FEIJOO A

HISTORIA CULTURAL

Inmaculada Urzainqui

Universidad de Oviedo 

Cando tanto proliferan os estudos históricos referidos ás letras, ás ciencias, ás artes ou, de querermos, á produción cultural en sentido amplo, resulta difícil imaxinar que houbo un tempo, non demasiado afastado, no que esas materias estiveron, se non ausentes, limitadamente representadas no coñecemento histórico. Pero así foi, como lamentaba o gran filósofo inglés Francis Bacon (1561-1626), xustamente ao propoñer a necesidade de incorporar ao saber historiográfico a «historia litteraria» ou "historia litterarum et artium», para entender na súa plenitude o proceso intelectual e avanzar nel con máis eficacia, no seu De dignitate et augmentis scientiarum (1623)1, isto é, a exposición rigorosa do curso evolutivo dos diversos coñecementos e artes. Unha historia que na súa formulación ía moito máis alá das achegas parciais feitas ata aquel momento, pois contería as orixes e o desenvolvemento das distintas doutrinas e artes que floreceron ao longo das idades do mundo, as «seitas» que se formaron e as controversias máis célebres mantidas entre os doutos, as calumnias que padeceron e os honores que recibiron, os inventos e as obras máis importantes en cada materia, as academias, colexios e sociedades científicas, a disposición dos diversos pobos para o exercicio das ciencias, os factores que contribuíron a favorecer ou entorpecer o desenvolvemento científico...; en fin, esa inmensa e dinámica cantidade de sucesos relacionados co saber ao longo do tempo sen o cal a historia do mundo é, segundo a súa gráfica comparación, «como la estatua de Polifemo sin su ojo ('eruto oculo'), sin aquello que mejor revela el espíritu y la vida de la persona».

E, en efecto, esa proposta, coma tantas outras da súa renovadora formulación do método científico, non quedou en simple aspiración. Asumida por moitos dos máis significativos historiadores da Ilustración como parte indisociable do coñecemento histórico, a historia literaria ${ }^{2}$ - a «historia do espírito humano» en axustada expresión de Saint-Aubin, Fontenelle, Voltaire, D’Alembert, Luis José Velázquez, os irmáns Rodríguez Mohedano e moitos outros- foi amplamente

1 É a tradución latina, ampliada, da primeira versión en inglés, Of the Proficiente and Avancement of Learning, Divine and Human, publicada en 1605. Cito por Bacon (1664).

2 Sobre a noción de literatura e historia literaria no século XviII, véxase Urzainqui (1987). A poderosa influencia de Bacon na historiografía cultural europea púxoa de manifesto Georges Gusdorf no capítulo II («Esquisse d'une histoire de l'histoire des sciences») do seu valioso libro de 1966. Para unha panorámica xeral dos máis importantes traballos realizados nesta liña en España, véxase Cebrián $(1996,1997)$ e Albiac (2011: 67-86). 
cultivada en toda a Europa culta, como o foron tamén outras parcelas da realidade humana desatendidas ata entón e que ademais pasaron a integrar o novo paradigma do suxeito histórico ${ }^{3}$. De moitas formas: como narración diacrónica, que sería o seu formato canónico, ou mediante moldes subsidiarios como repertorios biobibliográficos, dicionarios, vidas, eloxios, edicións e comentarios de textos, etc.; desde unha perspectiva xeral, ou concretada en calquera dos seus diversos ámbitos (matemáticas, física, poesía, dereito, música, etc.); atendendo ao legado do pasado, ou fixando a mirada no presente — en canto estadio tamén no devir do coñecemento- como será práctica habitual de innumerables periódicos de divulgación erudita como o Journal des Savants, as Mémoires de Trévoux, etc. En calquera caso, tratando de dar conta do proceso da cultura. E non só para fixar en termos máis precisos a imaxe do acontecer humano; a historia literaria cultivarase tamén no século XVIII porque se considera pórtico ineludible para avanzar no coñecemento, pola súa virtualidade para favorecer o espírito de renovación e mostrar o dinamismo e internacionalización da ciencia, e porque no clima de confrontación cultural entre as nacións que se vive daquela resultaba o medio máis pertinente para defender os valores patrios; algo particularmente acusado en España, como se fará patente en multitude de obras, algunhas tan significativas como a Historia literaria de España (1766-1791), dos irmáns Rodríguez Mohedano, primeiro intento de abarcar íntegro o curso evolutivo da cultura española; o Saggio storico-apologetico della letteratura spagnuola (1778-1781; trad. 1782-1786), de Lampillas, ou a Oración apologética por la España y su mérito literario (1786), de Forner, encamiñadas a engrandecer a cultura nacional e a contradicir, cada unha ao seu modo, a aqueles que desde o outro lado dos Pireneos acusaban aos españois de preguiceiros e inhábiles para xerar coñecementos importantes e, incluso, de influír negativamente — caso da poesía — noutras nacións.

En España, non obstante, esa nova visión manifestouse, ao igual que a propia Ilustración, con pasos bastante máis vagarosos que noutras partes. Evidenciábao en 1734 - cando Feijoo xa levaba un treito na súa carreira de escritor- a queixa de Gregorio Mayans, un dos intelectuais máis lúcidos e atentos á actividade bibliográfica do tempo, no ambicioso programa cultural que somete á consi-

3 Esta ampliación do espazo historiográfico na nova conciencia histórica da España do XVIII subliñouna José Antonio Maravall no seu fundamental estudo (1972). 
deración do ministro José Patiño: «La causa porque en España se cuida tan poco de la perfección de la historia es por lo poco que se estudia la literaria» ${ }^{4}$. E algo parecido dirá dez anos despois o Padre Sarmiento:

Si tomo un libro de historia en la mano, no tropiezo con otra cosa sino con un tejido continuado de guerras, con una fastidiosa repetición de oraciones que jamás han dicho los capitanes y, cuando más, con tal cual nacimiento, casamiento y muerte de príncipes, como si solo las acciones de éstos fuesen el único objeto de la historia. Ésta debe instruir a los hombres, presentándoles los sucesos más memorables, no solo belicosos, sino también físicos, cosmográficos, políticos, morales, teológicos y literarios. (Sarmiento 1775: 7)

E non lles faltaba razón, pois, malia xa hacer nas décadas precedentes algunha proposta nesa liña — como a que en 1680 bosquexa Francisco Gutiérrez de los Ríos, terceiro conde de Fernán Núñez (1644-1717), no seu preilustrado manual educativo El hombre práctico (Gutiérrez de los Ríos 2000: 150)5—, a maioría das historias seguían ignorando practicamente a historia literaria.

Isto non significa, porén, que estivese ausente do coñecemento histórico, pois, alén do tradicional interese dos científicos polas informacións procedentes de calquera época anterior, xa existiran diversas contribucións encamiñadas dun modo ou doutro a reconstruír o pasado cultural. No formato biobibliográfico, estaban as dúas importantes Bibliothecae de Nicolás Antonio, a Nova, editada en Roma en 1672, cun prefacio apoloxético sobre a cultura española, e a Vetus, publicada postumamente en 1696, tamén en Roma, grazas aos bos oficios do deán Martí e ao mecenado do cardeal Sáenz de Aguirre; a moito máis limitada Biblioteca Valentina de José Rodríguez, terminada en 1703 a pesar de se publicar en 1747, ou a moi posterior Bibliographia critica sacra et prophana (1740-1742) de frei Miguel de San José. Estaban tamén os notables traballos de Mayans (as súas biografías de Cervantes, Antonio Agustín e outros españois ilustres, a Oración en loanza de Saavedra Fajardo, a Noticia do verdadeiro autor de La picara Justina, as súas edicións da República literaria, das Cartas de Nicolás Antonio, Manuel Martí, etc.);

4 «Carta-Dedicatoria» da súa Colección de cartas civiles y literarias de varios autores españoles (1734). Publicada ese mesmo ano en edición separada como Pensamientos literarios (Mayans y Siscar 1983: 256).

5 Pode verse un matizado comentario da súa proposta no prólogo de R. P. Sebold e J. Pérez Magallón a esta edición e no libro de Pérez Magallón, 2002: 180-181. 
os humanísticos do seu mestre, o deán Martí, a maioría inéditos, ou, en fin, os de historiografía xurídica española de Juan Lucas Cortés, que logo publicaría o diplomático danés G. E. Franckenau, apropiándose deles.

Por outra parte, os novatores, ese admirable grupo de científicos e historiadores que desde as décadas finais do século XVII asentan as bases da modernidade ilustrada, tamén miraran o pasado das ciencias, ben para criticar a autoridade dos antigos ou os sistemas precedentes (López Piñero 1979), para reivindicar os aspectos máis innovadores da cultura áurea ${ }^{6}$, ben para mostrar os antecedentes da materia abordada, como fan Tomás Vicente Tosca nos seus dous famosos Compendium -o Mathemático (1707-1715), no que trata brevemente a «origen, progreso y utilidad de las matemáticas», e o Philosophicum (1721), introducido por unha revisión das diferentes escolas ou seitas filosóficas - e o coñecido defensor de Feijoo, Martín Martínez, no diálogo sobre historia da medicina que encabeza a súa Filosofía scéptica (1730). Desgraciadamente, o gran proxecto iniciado en 1727 polo marqués de Santa Cruz de Marcenado, o asturiano Álvaro Navia Osorio, de formar un Diccionario Universal de carácter enciclopédico quedou frustrado7 e tampouco efectuou a aspiración programática da Real Academia de la Historia de realizar historias particulares de ciencias e artes ${ }^{8}$.

De maneira que nesta fase temperá da historiografía cultural, na que Feijoo inicia a súa traxectoria literaria, son aínda moi limitados os materiais dispoñibles para ter unha idea cabal do curso da cultura e ninguén, que eu saiba, se ocupara especificamente diso.

6 Como sucede en Hipócrates aclarado y sistema de Galeno impugnado (1717), do médico Miguel Marcelino Boix y Moliner. Sobre este nesgo apoloxético dalgúns novatores, véxase o capítulo III («Identidad nacional y autodefensa») do citado libro de Pérez Magallón (2002). Ten moi en conta as apreciacións ao respecto de Quiroz-Martínez (1949), López Piñero (1979) e Martínez Vidal e Pardo Tomás (1995).

7 Para suplir a ausencia de «diccionarios históricos bíblicos, geográficos, matemáticos, económicos, jurídicos, químicos, geométricos, de comercio, de marina, música, etc.» como tiñan outras nacións. Expono nas súas Reflexiones militares (Navia-Osorio, 1984: 795). Para unha explicación máis pormenorizada deste, véxase F. López (1996) e Ruiz de la Peña (2012: 82-85).

8 Segundo o establecido no punto I dos seus Estatutos: «[...] será su primera empresa la formación de unos completos Anales, de cuyo ajustado y copioso índice se forme un diccionario histórico-crítico universal de España, y sucesivamente, cuantas historias se crean útiles para el mayor adelantamiento, tanto de las ciencias como de artes y literatos, que, historiadas, se hacen sin duda más radicalmente comprehensibles" (Fastos, 1739: 52. A cursiva é miña). Unha aspiración que, a raíz da complexidade das tarefas previas, quedou «al menos por muchos años en la esfera de los posibles», como lamentarán anos despois os irmáns Mohedano (1766: $\mathrm{X})$. 
Por iso creo que merecía a pena revisar a obra do sabio Padre Mestre á luz desas novas formulacións historiográficas e recoñecer, que é o que pretendo neste traballo, a súa importante contribución neses dous sentidos: o seu nobre esforzo por iluminar e divulgar aspectos significativos do pasado e presente das letras desde unha conciencia historicista, moderna, e a súa condición de pioneiro en tratar esta innovadora rama da historia nun texto monográfico.

\section{A «HISTORIA LITERARIA» NA OBRA DE FEIJOO}

Malia ser certo que a historia non figura entre os propósitos declarados que o animan a escribir e que, como se repetiu, non poida ser considerado como un historiador en sentido estrito (Fernández Conde 1976), creo que un percorrido atento polas páxinas do Teatro crítico (1726-1739) e as Cartas eruditas (1742-1760) permite recoñecer que Feijoo ten unha mente histórica, posúe unha impresionante erudición histórica — que en infinidade de ocasións pon a disposición das súas argumentacións—, e fai moita historia, aínda que polo carácter misceláneo e ensaístico da súa escritura non sexa de maneira regular e sistemática nin abunde en concrecións cronolóxicas; historia política e social —historia dos homes-, e, en maior medida, «historia literaria», intelectual, na liña da concepción historicista do seu admiradísimo Bacon ${ }^{9}$ e das súas directrices para debuxar a cambiante imaxe das producións do espírito humano: historia de coñecementos, doutrinas, e sistemas filosóficos e científicos, memoria crítica de figuras relevantes das letras, precisións e desmentidos sobre obras e autores non ben valorados, referencias críticas de libros e xornais, noticia de descubrimentos, controversias e sociedades científicas, exame da disposición e capacidade de persoas e nacións para o coñecemento... Todo un repertorio de materiais que, sen chegar a formar un relato organizado nin unha cabal construción histórica, aspecto que evidentemente non pretendía, puxeron ao alcance dos seus lectores moitas informacións de interese para calibrar e entender, desde unha cosmovisión ilustrada, o proceso evolutivo dos saberes e das artes, especialmente as grandes innovacións produ-

9 A profunda influencia de Bacon en Feijoo queda amplamente probada no estudo de Ivy L. Mc Clelland (1975). Non advirte, así e todo, este aspecto que estamos considerando. 
cidas no que logo se chamou a Revolución Científica. Algo máis valioso tendo en conta a escasa instrución dunha gran parte do seu público, da predominante concepción inmobilista da ciencia e da aínda exigua actividade tradutora de obras de carácter científico.

E, desde logo, o feito de facer Feijoo moita historia intelectual comprobámolo — por concisa e incompleta que sexa- na definición que na lección baconiana realiza Mayans na súa Retórica (1757):

La historia literaria refiere quáles son los libros buenos i quáles los malos, su méthodo, estilo i uso; los genios i ingenios de sus autores; los medios de promover sus adelantamientos o de impedirlos; los principios i progresos de las sectas eruditas; las universidades literarias; las academias i sociedades de varias ciencias i el estado de la literatura en ellas; i el adelantamiento o descuido de las naciones en cada género de ciencia. (Mayans 1984: 623)

Pero a Feijoo, non hai dúbida, a historia cultural en si mesma non o tenta como programa, porque, se fose así, faría unha cousa moi distinta. Non. O seu non é acumular erudición e forxar un relato unitario e sistemático ao estilo do que fan os seus irmáns de Saint-Maur coa súa Histoire littéraire de la France (1733-1763) ou o que farán despois os Rodríguez Mohedano coa súa inconclusa Historia literaria de España, por citar dous ambiciosos proxectos de horizonte nacional. Fai historia, si, pero de maneira máis persoal e selectiva, na medida en que convén ao seu propio programa de impugnar ideas equivocadas fortemente arraigadas e "proponer la verdad»; a verdade do que entende que importa saber e facer intelixible aos seus lectores, que no eido da actividade intelectual supón, aínda que non o declare expresamente, privilexiar unha serie de temas e aspectos que considera significativos para o coñecemento ou «desengaño» dos seus lectores avistándoos desde un enfoque temporal, á luz do progreso do coñecemento, da conquista do saber. Porque, como bo empírico, sabe moi ben que todo nas artes e nas ciencias, os seus avances, altibaixos e retrocesos, se produciu no devir da Humanidade — «la verdad es hija del tiempo, no de la autoridad» (recte enim veritas temporis filia dicitur, non auctoritas) sentenciara rotundamente Bacon no Novum Organum - e que, se quería familiarizar a cidadanía española cos mellores coñecementos modernos ou, pola contra, liberala de prexuízos e ideas equivoca- 
das, debía facelo desde a experiencia do coñecido, do que se dixera, e cando e como se dixera.

Por iso dicimos que hai historia, porque contempla e ordena as manifestacións culturais desde ese prisma, pois, aínda que non se prodigue en referencias cronolóxicas precisas e as súas indicacións ao respecto sexan frecuentemente moi superficiais, a linealidade do tempo e a gradación que outorga ás diversas épocas quedan patentes: «reprodujo esta opinión hará cosa de un siglo el célebre dominicano Fr. Tomás de Campanela», «la admirable exposición que poco ha dio a luz el sapientísimo benedictino D. Agustín Calmet», «Sirva de prueba el espejo ustorio, que no ha muchos años hizo el señor Villete, artífice excelente de León de Francia, cuya descripción se imprimió en Lieja el año de 1715, y se halla copiada en las Memorias de Trevoux del año de 1716», "el primero de quien hay noticias que las observó fue el padre Christóforo Scheinero, de la Compañía de Jesús, y con tanta aplicación que desde el año de 1611 hasta el de 1627 hizo mil y cuatrocientas observaciones de estas manchas, de que da noticia en su Rosa Ursina. El célebre Galileo Galilei empezó a observarlas casi al mismo tiempo que Scheinero, y fueron después continuando en la misma aplicación los más laboriosos astrónomos del siglo pasado y de este».

Pero como o seu non é facer unha historia sistemática, a presenza deses materiais histórico-culturais é descontinua e, aparentemente polo menos, bastante aleatoria, pois se unhas veces os introduce directamente, facendo dun asunto concreto o tema central dun discurso ou dunha Carta, outras faino ao fío das súas propostas ou do seu combate contra prexuízos e crenzas erróneas, como é o caso, por exemplo, do axustado resumo histórico dos sistemas médicos que ofrece no discurso "Medicina» xustificando o seu escepticismo médico (TC, I, 5), ou da relación de mulleres insignes «en todo género de letras» coa que apoia a súa tese en defensa da igualdade de talento das mulleres $(T C, 16)^{10}$. Pero, como digo, sen que se observe unha orde preestablecida.

O que está claro, en todo caso, é que non fala de oídas senón que todo o que di sobre o devir cultural descansa, máis alá do seu propio coñecemento de

10 Cito as obras de Feijoo pola primera edición, imprenta de Francisco del Hierro, actualizando ortografía e puntuación. Abrevio os títulos consonte o seguinte criterio: Teatro crítico universal (TC), Cartas eruditas y curiosas (CE), tomo, núm. de Discurso ou Carta. Para a Carta 10 do tomo IV teño en conta o texto, coidadosamente anotado, de Francisco Uzcanga Meinecke (2009). 
obras e autores, nunha rica bagaxe de lecturas de compoñente histórico-cultural. Españolas unhas, como as Bibliotecas, de Nicolás Antonio, que aprecia moito ${ }^{11}$, ou a Bibliographia critica sacra et prophana, de frei Miguel de San José, e, sobre todo, estranxeiras (francesas principalmente), entre elas destacan o Grand Dictionnaire historique (1674), de Louis Moréri; o Dictionnaire historique et critique (1695-1697), de Pierre Bayle; a Histoire de l'Académie Royale des Sciences, órgano dese relevante centro científico polo que sentiu profunda devoción, iniciada en 1699; a Histoire de l'Académie des Inscriptions et Belles Lettres —órgano pola súa vez da dita Academia—, que se empezou a publicar en 1717; a Histoire ancienne (1730-1738), de Rollin; a Censura celebriorum authorum (1690), de Thomas Pope Blount; las Mémoires pour servir à l'histoire et au progrès de l'astronomie, de la géographie et de la physique (1738), de Joseph Nicolas Delisle; a Bibliothèque universelle et historique (1686-1693), de Jean Le Clerc; as Réflexions sur la philosophie ancienne et moderne (1676), do P. Rapin; o Traité de l'Opinion ou Mémoires pour servir à l'histoire de l'esprit humain (1733), de Saint-Aubin, etc.

Loxicamente, estas consideracións invitarían agora a especificar con máis detalle a achega de Feijoo neste sentido. Pero como son tantos e tan variados os aspectos que trata, para dar unha idea tan sequera aproximada limitareime a resumir brevemente os seus principais núcleos.

O seu afán por plasmar a traxectoria de coñecementos, doutrinas e sistemas científicos e filosóficos cristaliza nun boa presa de discursos e cartas. Xa no tomo I do Teatro crítico aparece o citado resumo sobre a evolución da "Medicina», un discurso acerca dos sistemas cartesiano e gassendista ("Consectario contra filósofos modernos») e outro, "Música de los templos», no que ao fío da súa denuncia da profanación da música sagrada introduce diversas referencias sobre a música antiga e moderna. No tomo II, entrando de cheo nunha das súas grandes preocupacións histórico-filosóficas, ofrece unha ampla panorámica do aristotelismo e dos filósofos e sistemas que o viñan combatendo, particularmente o cartesiano ( Guerras filosóficas»), e tres visións monográficas sobre outras tantas cuestións con-

11 «No sería razón pasar en silencio a Don Nicolás Antonio, autor de la Biblioteca Hispana, obra, según la opinión universal, superior a cuantas bibliotecas nacionales han parecido hasta ahora, y que no se pudo hacer ni sin un trabajo inmenso ni sin una extensión dilatadísima de crítica» (Glorias de España», TC, IV, 14, 56). Véxase tamén TC, VI, 2, 100 e TC, VII, 7, 35, nos que o cualifica como «doctísimo y diligentísimo varón». 
trovertidas sobre as que quere pronunciarse («Peso del aire», «Esfera de fuego» e «Del antiperístasis»). No III bríndanos unha valiosa panorámica acerca do tamén debatido asunto da «Racionalidad de los brutos» e outra sobre o «Escepticismo filosófico». No IV volve de novo sobre o «Mérito y fortuna de Aristóteles y de sus escritos» — que desenvolve, segundo el mesmo constata, «siguiendo la serie de los tiempos»—, e no discurso «De lo que sobra y falta en la Física», a propósito da importancia do método experimental, destaca os avances realizados en España, mencionando como exemplos o «ingenioso jesuita Rodrigo de Arriaga» e o tamén xesuíta Luis de Losada. No discurso «Cuevas de Salamanca y Toledo, y mágica de España», que figura no tomo VII, ademais de facer un amplo percorrido histórico polas artes máxicas, detense para combater «la especie de que un tiempo hubo escuelas de las artes mágicas en varias partes de España». Xa nas Cartas eruditas, a 21 do tomo I, dedicada a descualificar a presunta «arte de memoria», inclúe un amplo reconto dos autores que a viñan sustentando, prestando particular atención a Juan Velázquez de Azevedo e ao "conde Nolegar Giatamor» [Girolamo Argenti]; a 23 do tomo II («Sobre los sistemas filosóficos») trata xustamente deles, en particular dos sucesivos de Descartes, Gassendi e Newton; e a 24 («Satisfacción a un reparo histórico-filosófico»), do pioneiro papel de Bacon en mostrar o desencamiñado rumbo dos sistemas filosóficos. Nesa liña van tamén dúas do tomo III («Sobre el sistema copernicano»e «Del Sistema Magno»), outras dúas do IV («De los filósofos materialistas», "Progresos del sistema filosófico de Newton, en que es incluido el astronómico de Copérnico») e unha do V («Establécese la máxima filosófica...»), onde, volvendo sobre o asunto da racionalidade dos brutos, trata amplamente das ideas de Gassendi e os filósofos materialistas, completándoo con dous apéndices, un contra os gassendistas e outro «en que se coteja el sistema de los filósofos materialistas con el de los pitagóricos». Como se pode advertir xa polos propios títulos, o seu interese prioritario neste grupo de escritos constitúeo a historia da Filosofía no amplo sentido que ten naquela época.

Desde esa perspectiva histórica fala tamén de moitos descubrimentos, experiencias, inventos e avances científico-técnicos; dalgúns con especial atención, como ocorre cos realizados modernamente nas matemáticas (TC, III, 7), o tempo do descubrimento de «las variaciones del imán» (CE, I, 5), o remedio da transfusión do sangue (CE, I, 16), a «medicina transplantatoria» (CE, I, 17), o «nuevo arte de beneficiar la plata» (CE, II, 19), o descubrimento da circulación do sangue 
feito por un albeite español (CE, III, 28) ou a invención da arte que ensina a falar aos mudos (CE, IV, 7).

As diferenzas de opinión en materias científicas, artísticas e filosóficas, moi presentes tamén na súa obra, merecen tratamento específico no xa citado «Guerras filosóficas» e en "El gran magisterio de la experiencia» (TC, V, 11), nos que, amais da súa apaixonada defensa do método experimental, ilustra as cautelas con que ha de practicarse con diversos exemplos de discrepancias de criterio sobre certas cuestións.

Convencido do decisivo papel das academias modernamente fundadas para o progreso científico, fala con manifesta admiración dalgunhas en distintos lugares da súa obra, particularmente das dúas francesas que mellor coñece a través dos seus órganos de expresión, a Académie Royale des Sciences e a de Inscriptions et Belles Lettres, e das dúas españolas consagradas á Medicina: a Regia Sociedad de Sevilla, da que se congratula ser nomeado membro honorario, e a Academia Médica Matritense, de creación máis recente (TC, VII, 14).

Como cabía esperar, a polémica entre antigos e modernos, que tanto viña axitando os medios intelectuais europeos desde finais do século anterior e que tan decisiva foi para formular a idea de progreso dos coñecementos (Nisbet 1980: 216-223; Albiac 2011:29-37), é o trasfondo de moitos dos seus xuízos e pronunciamentos. Pero, a pesar de estar, en xeral, cos modernos e ter o convencemento de que a antigüidade dunha doutrina non é proba da súa solidez, mostra a súa independencia de criterio — fronte á idea dun progreso continuado da culturadefendendo os antigos en varias ocasións; particularmente no discurso «Resurrección de las artes y apología de los antiguos» (IV, 12), dirixido a mostrar que o seu enxeño «en nada fue inferior al de los modernos» e a probar que moitas doutrinas e descubrimentos en ciencias e artes que consideran modernos foron moi anteriores, e na Carta «Maravillas de la música y cotejo de la antigua con la moderna» (I, 44), que é unha confrontación entre os valores dunha e outra para poñer de manifesto que os daquela en nada desmerecen da pretendida superioridade desta.

Outra gran liña de forza que percorre practicamente toda a súa obra é a valoración crítica de autores — filósofos, científicos, poetas, historiadores...-, desde a Antigüidade ata o presente. Unhas veces circunstancialmente, ao fío do tema que está tratando, e outras de maneira máis decidida, como sucede con Aristóteles, Lucano, Descartes, Gassendi, «el gran Newton», Raimundo Lulio, os médicos 
sevillanos Juan Vázquez Cortés e Manuel Mastrucio, Enrique Flórez, o P. Codorniú, o P. Rodríguez ou o médico español Francisco Solano de Luque.

Este empeño, aderezado cunha vontade apoloxética, toma corpo en «Apología de algunos personajes famosos en la historia» (TC, VI, 2), escrito para rebater as acusacións infamantes feitas a diversos personaxes históricos, entre eles figuras notables do pensamento como Empédocles, Demócrito, Epicuro, Plinio o Maior, Apuleyo e Enrique de Villena.

Nesta liña reivindicativa móvese tamén, cun nesgo marcadamente patriótico, a segunda parte de "Glorias de España» (TC, IV, 14), encamiñada a defender os valores da cultura patria («la habilidad intelectual de los españoles con extensión a todo género de materias»), cun catálogo dos principais eruditos, poetas, historiadores e científicos españois, particularmente dos últimos séculos, que mereceron honores e recoñecemento de autores estranxeiros.

Por último, e seguindo as propostas baconianas para a historia cultural, hai tamén dous aspectos que reclaman a súa atención: a capacidade de raciocinio e a disposición para o coñecemento dos pobos, así como os factores que contribuíron a un maior avance dunhas nacións, como Inglaterra ou Francia, con relación a outras ou ao considerable atraso en materia científica, caso de España. O primeiro, que ninguén antes examinara en España (Maravall 1991 [1972]: 134), plásmase especialmente en dous discursos do Teatro crítico: «Mapa intelectual y cotejo de naciones» (II, 15), encamiñado a poñer de manifesto que, no substancial, non hai pobos máis dotados ca outros para o raciocinio aínda que si no accidental de axilidade, sutileza, etc., no que outorga clara superioridade aos ingleses, e «Responde el autor a un tertulio que deseaba saber su dictamen en la cuestión de si en la prenda del ingenio exceden unas naciones a otras» (IV, 13), onde amplía e matiza o sinalado no anterior; e o segundo en «De lo que sobra y falta en la Física» (TC, VII, 13), "De lo que sobra y falta en la enseñanza de la Medicina» (TC, VII, 14), «Causas del atraso que se padece en España en orden a las ciencias naturales» (CE, II, 16) e «Sobre el adelantamiento de ciencias y artes en España, y apología de los escritos del autor» (III, 31). Nesta liña móvense tamén, malia levar a idea a outros eidos, as súas dúas importantes alegacións, unha en defensa da igualdade de talento das mulleres (TC, I, 16) e outra, «Españoles americanos» (TC, IV, 6), contra a estendida crenza da anticipada decrepitude intelectual dos crioulos poñendo á vista unha selecta nómina de personaxes ilustres en letras. 


\section{A HISTORIA LITERARIA COMO DISCIPLINA INTELECTUAL}

Pero, como antes indicaba, a achega de Feijoo á historia literaria vai máis alá de dar a coñecer aspectos significativos do proceso cultural e de perfilar a súa imaxe no tempo. A el debémoslle tamén o que creo que é o seu primeiro tratamento monográfico como empresa intelectual claramente definida. Refírome á carta «Respondiendo a una consulta sobre el proyecto de una historia general de ciencias y artes» (CE, IV, 10, 1753), coa que contesta, segundo apunta o título e especifica o propio Feijoo, á petición dun innominado conde, grande admirador seu, que proxecta construír esa ambiciosa historia cultural, e cuxo fío condutor é, en efecto, proporcionar as pautas necesarias para iso:

Muy señor mío: Aún no del todo convalecido de una penosa fluxión que padecí estos días y me hizo retardar la respuesta a la carta de V. S., digo que recibí esta con singular estimación por lo mucho que V. S. me honra en ella, suponiendo mera liberalidad al mérito que no tengo; en cuya cuenta entra también el considerarme apto para satisfacer a V. S. sobre la consulta que me hace en orden al gran proyecto literario que ha concebido de Historia General de Ciencias y Artes, y en que cuanto yo puedo hacer es representar a V. S. la arduidad de la empresa.

A petición en si mesma non ten nada de estraño no deseño xeral das Cartas eruditas pois, salvo unhas poucas, todas aparecen como escritas en resposta a preguntas, propostas ou reparos dun correspondente. E tampouco sorprende que non diga o nome de quen lle escribe, porque é o que acostuma, nin que omita a data da carta, pois só o fai en contadas ocasións. O que está claro, en todo caso, é que a escribe antes de 1753 (a dedicatoria á raína do tomo IV, no que aparece esta Carta, vai datada o 8 de xaneiro dese ano) e que é, polo tanto, anterior ás dúas reflexións máis significativas que coñezo sobre o tema neses anos, a mencionada definición de Mayans e o prólogo, moito máis ambicioso desde o punto de vista epistemolóxico, dos Mohedano á súa Historia literaria de España.

Maior problema é saber se tal petición se produciu realmente e o texto publicado reproduce a contestación que no seu día lle deu Feijoo ao seu correspondente, como se pode verificar en bastantes casos (Urzainqui 2014), ou se é unha ficción para se estender sobre o tema. Desde logo, se o proxecto — sen compa- 
ranza na Europa daquela - se materializase dalgún modo a resposta sería bastante fácil. Pero non é así, ou polo menos eu non coñezo ningunha iniciativa en tal sentido por eses anos (a Historia literaria dos Rodríguez Mohedano responde a un plan que se afasta moito da historia universal obxecto de tratamento aquí e Origen, progresos y estado actual de toda la literatura de Juan Andrés, que si podería encaixar, é de data moi tardía, pois publícase entre 1782 e 1799). E tampouco me foi posible identificar a personalidade dese presunto correspondente cos candidatos en que verosimilmente cabería pensar (Luis José Velázquez, o conde de Peñaflorida, Campomanes... ${ }^{12}$ ). Sexa como for e aínda que a incógnita siga en pé, o importante é que é un texto seu e que o publica porque considera que pode ser de interese e de utilidade para os seus lectores, igual que fai con diversas contestacións que escribira antes a destinatarios concretos. Neste caso, parece claro co obxecto de servir de guía bibliográfica a quen quixese avanzar no coñecemento histórico da cultura, que acaso non serían poucos dada a efervescencia historicista que se vivía daquela, a cuxo lado estaban tamén os plans gobernamentais de crear unha Academia de Ciencias, Belas Letras e Artes que, lamentablemente, non chegaron a se materializar (Álvarez de Miranda 1993).

Mais, a pesar de apuntar a ese obxectivo básico o substancial da Carta, como o motivo declarado é responder a consulta sobre ese "gran proyecto literario» que concibiu o seu correspondente, o desenvolvemento discorre de acordo con ese patrón, expón en primeiro lugar as dificultades de realizar semellante proxecto e a necesidade de traballar en equipo con persoas cualificadas, e logo pormenoriza as fontes bibliográficas máis apropiadas para tal fin, que é a parte máis extensa, e, como digo, a de maior interese para un público xeral. Non entra a considerar, en cambio, outras cuestións que serían de grande interese historiográfico, como o valor ou o modo de construír esa historia, aínda que, polo que dirá despois, ben poderían entrar nesoutra carta, con maiores precisións, que lle promete escribir se finalmente o proxecto se pon en marcha.

Para Feijoo está claro que tal empresa «no es obra para un hombre solo ni para tres, cuatro o cinco, sino para muchos, y éstos muy versados en las facultades cuya

12 Este punto desenvólvoo con máis amplitude en «Feijoo en los inicios de la historiografía de la cultura», en María Dolores Gimeno Puyol e Ernesto Viamonte Lucientes (coords.), Los viajes de la Razón. Estudios dieciochistas en homenaje a María-Dolores Albiac Blanco, Zaragoza, Institución Fernando el Católico, 2015, 103-123. 
historia se intenta, uno en cada una», aínda que puidese haber algún que abarcase comodamente tres ou catro. Se houbese «historias particulares de todas esas facultades», talvez non sería mester tanto; pero sempre será moito, pois, aínda que para resumir a historia de calquera facultade non se precise un coñecemento profundo dela, necesítase bastante máis que un simple verniz superficial («aquello que se llama meramente tintura»). Esa consideración lévao a facer unha breve digresión sobre a diferenza existente entre coñecer ben, metodicamente, unha disciplina e crer que se coñece porque se leu algo sobre ela, como se ve neses «aventureros de la República Literaria» que «sin vocación, sin ingenio, sin estudio» e con catro libros mal lidos se lanzan a publicar absurdos e monstruosidades. Por iso, o primeiro que habería que facer é buscar persoas capaces de formar as distintas historias disciplinarias e lograr, aspecto tampouco fácil, que estean dispostas a traballar:

Pase esto por digresión; y volviendo al propósito, digo que creo que, aun fuera de lo mucho que V. S. podrá hacer por sí mismo, habrá en la Corte sujetos bastantes para extractar muy bien las historias que haya escritas de muchas ciencias y artes, ya que no de todas. ¿Pero querrán todos los que son hábiles para ello dedicarse a ese trabajo? Mucho lo dificulto. Unos estarán empleados en otras tareas que considerarán más útiles para sus personas. Otros se hallarán ligados de obligaciones, o políticas o morales, que les impedirán trabajar para la imprenta. Otros tendrían otros obstáculos.

No caso de conseguir ese equipo de especialistas, pasa xa a propoñer «los libros necesarios para esa gran colección», non sen advertir, para que ninguén se equivoque, que «son pocos los que hay de historias particulares de ciencias y artes», polo menos os que chegaron ao seu coñecemento.

Procedendo co seu habitual bo sentido, distingue, por un lado, catro materias específicas - filosofía, medicina, ciencias matemáticas, e pintura e arquitectura- e, por outro, repertorios de carácter más xeral que poidan subministrar información sobre todas as demais. O feito de que ningún sexa español indica con claridade que nada do que había aquí satisfacía as súas expectativas.

Comezando pola historia da filosofía, remite para a antiga a «los dos tomos que escribió el inglés Thomas Stanley», nos que se poderá encontrar "cuanto se puede desear» sobre a materia. E para os tempos posteriores, ademais de varios 
discursos seus, o Origine ancienne de la physique nouvelle (1734) do xesuíta francés Noël Regnault (1683-1762):

Para continuar desde allí la historia hasta nuestros tiempos hallará V. S. muchos materiales en varios discursos del Teatro crítico, v. gr. «Guerras filosóficas», «El gran magisterio de la experiencia», «Mérito y fortuna de Aristóteles», etc. Pueden conducir al mismo asunto los tres libritos del padre Regnault cuyo título es Origen antiguo de la física moderna.

A obra de Stanley, primeira das rotuladas como «historia de la filosofía», é a célebre The History of Philosophy: containing the Lives, Opinions, Actions and Discourses of the Philosophers (Londres, 1656-1660), escrita baixo a inspiración enciclopédica de Bacon (Giolito, 2008: cap. 2) para dar a coñecer cronoloxicamente a vida e opinións dos filósofos «de todas las sectas». Moi difundida en Inglaterra, foi tamén amplamente coñecida en Europa mediante a súa tradución latina (Leipzig, 1711, 2 vols.), que é a que coñece e cita Feijoo en varias ocasións. A segunda, como anuncia o título, ofrece unha comparación entre a nova física e a antiga, reivindicando para esta un gran número de inventos e ideas novas. Tanto esta obra coma os Entretiens physiques d'Ariste et d'Eudoxe ou Physique nouvelle en dialogues (1729), á que Feijoo recorre en numerosas ocasións, atopábanse na súa biblioteca (Hevia Ballina 1976: 165). En canto aos seus propios discursos, a súa soa referencia proba claramente que os escribiu desde un enfoque netamente historicista.

Pasando á medicina, recomenda un texto fundamental do saber histórico-médico (López Piñero 1992: 30), a difundida Histoire de la Médecine, "ou l'on void l'origine, et les progrès de cet art de siècle en siècle depuis le commencement du monde» (Ginebra, 1696), de Daniel Le Clerc, amais do seu propio discurso «Medicina»: «La historia de la medicina escribió Daniel Le-Clerc docto médico de Ginebra. Es verdad que no se extiende más que hasta Galeno; pero hizo después un plan de continuación hasta nuestros tiempos que puede servir mucho. Y algo hay conducente en mi discurso sobre la Medicina».

Tamén fundamental é o que recomenda para as matemáticas: a exposición histórica que precede ao completo Cursus seu mundus mathematicus... (Lyon, 1674), de Claude-François Milliet Dechales, autor moi admirado e repetidamente citado por el (tíñao tamén na súa biblioteca), no que, efectivamente, aparecen 
consignados os máis importantes «progresos» que se fixeron desde a Antigüidade ata o presente nos distintos campos físico-matemáticos contemplados na obra.

Sobre a historia da música, en cambio, non cita autor determinado, senón que remite aos traballos acerca do tema contidos na prestixiosa Histoire de l'Académie des Inscriptions et Belles Lettres, que tamén coñece moi ben —estaba subscrito a ela (Hevia Ballina 1982: 140)_ e utiliza con frecuencia, sobre todo nas Cartas eruditas: «De la música se puede formar historia casi completa de los muchos materiales que hay para ella en la Historia y Memorias de la Academia Real de las Inscripciones y bellas letras. En el tomo undécimo, que es índice de los diez precedentes, V. Musique, verá V. S. notados todos los lugares donde hay dichos materiales».

Para a pintura e arquitectura propón, respectivamente, os Entretiens sur les vies et sur les ouvrages des plus excellents peintres anciens et modernes (1666-1668), de André Félibien, historiador oficial da corte de Luis XIV e membro das Academias de Arquitectura e Inscricións, e o Recueil historique de la vie et des ouvrages des plus célèbres architectes (1687), do seu fillo Jean-François, tamén arquitecto e membro de ambas as dúas corporacións. Malia ser posible que as utilizase para algunhas referencias artísticas, só as menciona nesta ocasión.

Por último, a falta de historias formadas, indica «tres fuentes copiosas de noticias para la historia de ciencias y artes, que son el Theatrum Vitae Humanae de Lorenzo Beyerlink, las Memorias de Trévoux, y los tres tomos últimos de la Historia Antigua de Monsieur Rollin». A primera é o Magnum Theatrum Vitae Humanae, «ad normam polyanteae dispositum» (Colonia, 1631), do xesuíta flamenco Lawrence Beyerlinck, unha voluminosa enciclopedia de materias diversas que Feijoo manexa e cita en varias ocasións, a pesar de que, segundo o seu propio comentario, non sexa fiable de todo:

[...] no hay sino buscar por el orden alfabético el nombre de la facultad de quien se desean las noticias y debajo de él se hallarán. V. gr., quiere V. S. noticias conducentes para la historia de la jurisprudencia, en el cuarto tomo, pág. 748, verá el título Ius. Jurisprudencia, y, consiguientes a él, trece hojas llenas de especies pertenecientes a esta ciencia. Es verdad que el autor de esta dilatada obra suele ser poco exacto: defecto común a los que toman por su cuenta muy abultadas colecciones. 
A segunda, que con razón considera de moita máis utilidade para os seus fins, é a importante revista cultural Mémoires pour servir à l'Histoire des Sciences et des Arts (1701-1767), máis coñecida como Mémoires ou Journal de Trévoux por estar publicada por un equipo de xesuítas en Trévoux, unha das más difundidas entre a intelectualidade europea e española, e a máis admirada e frecuentada por Feijoo ${ }^{13}$ :

Las Memorias de Trevoux contribuirán con grandes y más seguros socorros para el asunto; grandes, porque ésta dilatada obra fue y está dedicada a ese fin; y así le pusieron y ponen sus autores el título de Memorias para la Historia de las Ciencias y Bellas Artes, más seguros, por la mejor crítica y más ciencias de los autores, porque, como son muchos los que trabajan asociados en esta obra dividiendo entre sí los asuntos, abarca cada uno solo aquello que es proporcionado a su estudio, inteligencia y comprensión.

Efectivamente, concibida como un rexistro da actualidade cultural europea — «historia literaria» do día (Urzainqui 1987: 584-587)—, as súas páxinas, nutridas de recensións críticas das novidades bibliográficas, noticias de descubrimentos, actividades de academias, universidades, etc., foron unha espléndida ventá para se asomar aos últimos compases do coñecemento e das artes. E, como quen o ten ben experimentado, explica como se han de manexar para encontrar facilmente as informacións:

El modo de usar de dichas Memorias es recurrir a la tabla que hay al fin de cada año, donde en distintas divisiones se coloca el índice de todos los escritos de que se dio noticia en los cuatro tomos pertenecientes a aquel año, poniendo las distintas materias debajo de los títulos correspondientes, v. gr. debajo del título Medicina se citan en sus respectivos lugares los libros pertenecientes a esta facultad de que se hizo crisis o extracto en aquellos cuatro tomos; lo mismo debajo de los títulos: Poesía, Música, etc.

E a terceira é a difundida Histoire ancienne, de Charles Rollin (1730-1738), e tamén citada por el en varias ocasións, en cuxos tres últimos tomos di: «tendrá V.S. un servicio muy pronto, porque en ellos trata el autor de varias ciencias y

13 No inventario da súa biblioteca, Hevia Ballina consigna 245 volumes da revista. Sobre a súa importancia na obra de Feijoo, véxase Ceñal (1966), Sáenz de Santamaría (1983) e Urzainqui (2004). 
artes apuntando el progreso que han tenido desde la antigüedad hasta nuestros tiempos. Es autor muy exacto, claro y de bello juicio, aunque en esta materia no da muchos materiales porque procede muy compendiariamente».

Unha vez feitas estas recomendacións sobre as ciencias profanas, engade unha última sobre a historia da Teoloxía que lle dá pé a facer unha interesantísima confesión autobiográfica: para evitar «el peligro de caer en innumerables y crasísimos errores», cre que sería mellor excluíla do proxecto a non ser que se encargue dela un teólogo moi douto e capacitado. El tamén tivo a intención de formala, pero finalmente desistiu por consello de persoas de confianza que lle fixeron ver a superior necesidade da «literatura mixta cuyo rumbo había tomado» e pola súa propia convicción de que tal como a formulara resultaría inabarcable.

Ao final, e como despedida, expresa a confianza de que o seu correspondente lle avise se empeza a executar o proxecto e a súa promesa de lle subministrar, se así fose, «algunas noticias o reflexiones conducentes a su prosecución»; unha promesa que é tácito recoñecemento de que habería bastante máis que dicir e, tamén, máis obras que mencionar. Porque, efectivamente, malia seren realmente valiosas as que recomenda, podería incluír outras máis que coñece e manexa habitualmente, como os dicionarios de Bayle e Moréri ou a Histoire de la Académie Royale des Sciences, por non falar doutra particularmente significativa por ser a primeira mostra de historia enciclopédica, a Histoire littéraire de la France publicada polos seus «sabios» irmáns de hábito de Saint-Maur, que, sorprendentemente, non parece coñecer. Sexa como for, bastaba o dito para que calquera lector interesado puidese saber a onde acudir para ter cabal información do proceso evolutivo das artes e das ciencias.

Pero aínda que con iso podería dar a Carta por concluída, a modo de corolario engade despois unha «Noticia curiosa relativa a un punto de la Carta antecedente», na que dá conta - a partir do extracto dunha carta comunicada a un dos redactores das Mémoires de Trévoux por «un miembro de la Sociedad Regia de Londres» [Andrew Michael Ramsay] e publicada en $1732^{14}$ — do prodixioso caso de «Mons. Stone», o brillante matemático e músico Edmund Stone, que, sendo fillo dun xardineiro do duque de Argile [Argyll] e analfabeto ata os 18

14 «Lettre de M. le C. D. R au P. C. J», janvier, 1732, 109-113. A autoría do escocés A. M. Ramsay (1681-1743) identifícaa Uzcanga (2009: 232). 
anos, logrou adquirir vastos coñecementos científicos grazas ao seu gran talento e extraordinario interese: proba de que «un gran genio supera todas las incomodidades de la fortuna, del nacimiento, de la educación» e de que, aínda sen voz viva de mestre e con só o auxilio dos libros, se pode «llegar a poseer ventajosamente esta o aquella facultad».

Ese «punto antecedente» era, sen dúbida, o que fixera na súa digresión sobre a esixencia de proceder con método e seriedade no estudo para chegar a alcanzar o verdadeiro coñecemento de calquera materia. Aínda que, efectivamente, a noticia non tiña demasiado que ver co preciso obxecto da Carta — como sucede con tantas outras digresións que lle gusta facer cando algo de interese lle vén á mente- era unha magnífica lección para estimular unha vez máis o afán de aprender — de aprender ben — dos seus lectores. Porque iso era, en esencia, o que viña pretendendo desde o comezo da súa carreira literaria. Creo que esta Carta e esa perspectiva histórica na percepción do saber que quixen mostrar aquí son proba elocuente diso. 


\section{REFERENCIAS BIBLIOGRÁFICAS}

Albiac Blanco, María-Dolores (2011): Historia de la literatura española. 4. Razón y sentimiento. El siglo de las Luces, Barcelona, Crítica.

Álvarez de Miranda, Pedro (1993): «Las Academias de los novatores», en Evangelina Rodríguez Cuadros (ed.), De las Academias a la Enciclopedia: el discurso del saber en la modernidad, Valencia, Edicions Alfons el Magnànim, 265-300.

[BACON, Francis] Francisci Baconi de Verulamio (1664): Opera omnia, Frankfort, Impensis Joh. Baptistae Schönwetteri, Typis Matthaei Kefferi.

Cebrián, José (1996): «La historia literaria», en Francisco Aguilar Piñal (ed.), Historia literaria de España en el siglo XVIII, Madrid, Trotta / CSIC, 513-592.

Cebrián, José (1997): Nicolás Antonio y la Ilustración española, Kassel, Reichenberger.

Ceñal, Ramón (1966): «Fuentes jesuíticas francesas de la erudición filosófica de Feijoo», en VV. AA., El P. Feijoo y su siglo, Oviedo, Cátedra Feijoo, II, 285-314.

FAstos de la Real Academia Española de la Historia (1739), Madrid, Antonio Sanz.

Fernández Conde, Javier (1976): «Feijoo y la ciencia histórica», en Fray Benito Jerónimo Feijoo, fe cristiana e Ilustración, Oviedo, Seminario Metropolitano, 75-113.

Giolito, Christophe (2008): Comprendre l'histoire de la philosophie, París, Armand Colin.

GUTIÉRREZ DE LOS Ríos, Francisco (2000): El hombre práctico, o discursos varios sobre su conocimiento y enseñanzas. Por Don —, conde de Fernán Núñez. [Introdución, ed. e notas de Jesús Pérez Magallón e Russell P. Sebold]. Córdoba, Publicaciones Obra Social y Cultural Cajasur.

Gusdorf, Georges (1977): Les sciences humaines et la pensée occidentale. T. I. De l'histoire des sciences à l'histoire de la pensée, París, Les Éditions Payot, [1ª ed., 1966].

Hevia Ballina, Agustín (1976): «Hacia una reconstrucción de la librería particular del P. Feijoo», en Fray Benito Jerónimo Feijoo, fe cristiana e Ilustración, Oviedo, Seminario Metropolitano, 139-186.

Hevia Ballina, Agustín (1982): «El P. Feijoo desde su biblioteca: sus aficiones histórico-geográficas», Yermo, 20:1-2, 111-148.

López PIŃERo, José María (1979): Ciencia y técnica en la sociedad española de los siglos XVI y XVII, Barcelona, Labor Universitaria.

López, François (1996): «Los novatores en la Europa de los sabios», Studia Storica. Historia Moderna, 14, 95-111.

Maravall, José Antonio (1972): «Mentalidad burguesa e idea de la Historia en el siglo XVIII», Revista de Occidente, 107 (febreiro), 250-286. [Reed. en Estudios de la historia del pensamiento español (siglo XVIII), introd. e compilación de Ma Carmen Iglesias, Madrid, Mondadori, 1991].

MARTíneZ VidAL, Alvar / José PARDo TOMÁs (1995): «In tenebris adhuc versantes. La respuesta de los novatores españoles a la invectiva de Pierre Régis», Dynamis, 15, 301-314.

MaYAns y Siscar, Gregorio (1983): Obras completas. I. Historia. [Ed. Antonio Mestre Sanchís]. Valencia, Ayuntamiento de Oliva / Diputación de Valencia.

MaYANS y SISCAR, Gregorio (1984): Obras completas, III, Retórica. [Ed. Antonio Mestre]. Valencia, Ayuntamiento de Oliva / Diputación de Valencia.

McClelland, Ivy L. (1976): «The signifiance of Feijoo's regard Bacon», en Fray Benito Jerónimo Feijoo, fe cristiana e Ilustración, Oviedo, Seminario Metropolitano, 249-274. 
[Navia Osorio, Álvaro] Marqués de Santa Cruz de Marcenado (1984): Reflexiones militares por el —. [prólogo de Jesús Evaristo Casariego]. Oviedo, Instituto de Estudios Asturianos.

Nisbet, Robert (1980): Historia de la idea de progreso, Barcelona, Gedisa.

Pérez Magallón, Jesús (2002): Construyendo la modernidad: la cultura española en el 'tiempo de los novatores' (1675-1725), Madrid, CSIC, Instituto de la Lengua Española.

Quiroz-MARTínez, Olga (1949): La introducción de la filosofía moderna en España: el eclecticismo español de los siglos XVII y XVIII, México, El Colegio de México.

Rodríguez Mohedano, Pedro e Rafael (1766), Historia literaria de España, desde su primera población hasta nuestros días... Por los PP. —, Madrid, Antonio Pérez de Soto, t. I.

Ruiz de la Peña Solar, Álvaro (2012): La hora de Asturias en el siglo XVIII, Oviedo, Real Instituto de Estudios Asturianos / Instituto Feijoo de Estudios del Siglo XVIII.

Sáenz de Santa María, Carmelo (1983): «Feijoo y las Memorias de Trévoux», en VV. AA., II Simposio sobre el padre Feijoo y su siglo, vol. II, Oviedo, Cátedra Feijoo, 53-60.

Sarmiento, Martín (1775): Obras póstumas del Rmo. P. M. Fr. Martín Sarmiento, benedictino. Tomo Primero. Memorias para la historia de la poesía y poetas españoles, Madrid, Joaquín Ibarra [terminadas en 1745].

URZAINQUI, Inmaculada (1987): «El concepto de historia literaria en el siglo XVIII», en Homenaje a Álvaro Galmés de Fuentes, Madrid, Universidad de Oviedo / Editorial Gredos, 565-589.

URZAINQUI, Inmaculada (2004): «El discurso de Feijoo sobre la prensa», en Isaías Lerner / Robert Nival / Alejandro Alonso (eds.), Actas del XV Congreso de la Asociación Internacional de Hispanistas, t. III, Newark, DE, Juan de la Cuesta Press, 611-622.

URZAINQUI, Inmaculada (2014): «Estudio introductorio», en Benito Jerónimo Feijoo, Obras completas. Tomo II, Cartas eruditas y curiosas I. [Ed. Inmaculada Urzainqui e Eduardo San José]. Oviedo, Instituto Feijoo de Estudios del Siglo XVIII / Ayuntamiento de Oviedo / KRK.

URZAINQUI, Inmaculada (2015): «Feijoo en los inicios de la historiografía de la cultura», en María Dolores Gimeno Puyol / Ernesto Viamonte Lucientes (coords.), Los viajes de la Razón. Estudios dieciochistas en homenaje a María-Dolores Albiac Blanco, Zaragoza, Institución Fernando el Católico, 103-123.

Uzacanga Meinecke, Francisco (2009) (ed.): Benito Jerónimo Feijoo, Cartas eruditas y curiosas [antología], Barcelona, Crítica. 

VIXENCIA ACTUAL DO PENSAMENTO XURÍDICO-SOCIAL DO PADRE FEIJOO

Luis Rodríguez Ennes

Universidade de Vigo 



\section{O MARCO HISTÓRICO: A ILUSTRACIÓN}

No ano 1784 Kant contestaba a pregunta Was ist Aufklerung? (Que é a Ilustración?) cunha reflexión sobre o uso libre da razón que emanciparía ao home da tutela das antigas crenzas (Kant 1784). Esta razón, a mesma que no Renacemento desenvolvera un espírito humanista enfrontado ao espírito teolóxico medieval, sería a base dunha nova cultura forxada, en esencia, na baixa modernidade a partir dunha revolución metodolóxica que transformou o coñecemento humano facéndoo crítico e experimental.

Este novo método empírico feito de orde e precisión, desenvolvido polo pensamento matemático e xeométrico do século XVII, púxose finalmente ao servizo das ciencias do home e da natureza. Así, a finais do século XVII, a física newtoniana, a partir de feitos probados, fixa as leis da natureza superando o racionalismo abstracto cartesiano. Por esta época, Locke redacta en dous tratados un novo código de política moderna e de entendemento humano coas súas virtudes de tolerancia, beneficencia e humanidade (Locke 1690). Por último, nas Universidades de Heidelberg, Halle e Gotinga, autores como Puffendorf, Thomasius, Wolff ou Heineccius, aplicando só a razón ao coñecemento do dereito natural, acabaron por desligar a lei humana da divina.

A razón, convertida en arma da nova cultura, faise crítica e universal, enfrontándose a unha concepción do mundo profundamente marcada por máis de mil anos de cristianismo. A imitación dunha onda laica do espírito libertario da Reforma, esta razón, segundo Leibniz, provén dun norte xermánico capaz de adoutrinar un mundo latino que apenas transmite outra luz que a tenue da tradición. Dela nace unha nova civilización que se coñece en todas as partes co nome de Ilustración ou as Luces (Les Lumiers, I Lumi, Die Aufklerung, The Enlightenment, As Luzes) por oposición a unha presunta escuridade anterior, semellante á noite gótica ou medieval dos renacentistas. No constante peregrinar de Minerva sobre a terra, a luz pousou agora en Europa: «En saliendo de Europa todo se nos figura barbarie» dirá Feijoo e, así, será concibida polos ilustrados españois (Sánchez Agesta 1995 3: 27) máis coma un espazo cultural que unha área xeográfica.

No século XVIII, Francia non tiña un rei da importancia dos mellores déspotas ilustrados, pero contaba cunha clase media poderosa, punto de partida dos raios das «luces». Inmediatamente ao sur estaba España, inmellorablemente situada 
para recibir a influencia do concepto laico da vida, pero era a nación que desde había séculos mantivera con maior tesón a relixión católica no seu chan e a sostivera co seu ouro e co seu sangue no estranxeiro. Tamén experimentara a perda de importancia de comerciantes e industriais desde o século XVI, mentres a súa nobreza - unha das máis orgullosas de Europa- conservara a totalidade das súas terras. Todo parecía indicar que, malia estar tan próxima ás Luces, España non se vería iluminada por elas (Herr 1975: 8).

Esta transformación impúxoa para si Feijoo como misión: «Las obras de este sabio produxeron una fermentación útil, hicieron empezar a dudar; dieron a conocer otros libros muy distintos de los que había en el país, excitaron la curiosidad; y al fin abrieron la puerta a la razón que antes había cerrado la indolencia y la falta de sabiduría» (cfr. Sempere y Guarinos 1785-1789, 3: 24). Xuízo que completa o anterior de Campomanes: «El prurito de contradecirle movió a muchos al estudio de materias que a no ser por esta causa les serían siempre desconocidas. El fruto consiguiente fue el de promoverse el buen gusto y generalmente en la nación desde entonces y enseñarse a tratar en la lengua materna todo género de asuntos científicos» (Anónimo 1769: 19). No seu papel de rexenerador da vida intelectual española repite unha e outra vez as súas dúas máis importantes leccións: a experimentación nas ciencias e mais o espírito crítico nos asuntos intelectuais, de maneira que se a palabra «enxeño» serviu para representar a nosa cultura barroca, será agora o termo «crítico» o que defina a nova cultura das luces á que Feijoo serve (Lázaro 1986: 21).

Con erudición e bo xuízo, servido por un estilo que o P. Flórez cualifica de «inigualable» e que el mesmo define "como lo contrario de artificio, esto es, la naturalidad, la abertura de ánimo, la sinceridad, el candor», inicia na súa madurez unha obra vencedora de falsas crenzas, prexuízos e ignorancia que en poucos anos —os que van desde a aparición do Teatro crítico universal (1726) ata a última das súas Cartas eruditas y curiosas (1760) — modificará o panorama cultural español.

Grazas ao seu esforzado labor, este panorama ofrécese distinto cando a primeira xeración de homes do XVIII (Luzón, Sarmiento, Torres, Mayáns, Flórez ou Isla) se asoma aos campos do saber. De aí que o devandito reitor da Sorbona descubra con sorpresa no século XVIII «el esfuerzo gigantesco de un puñado de hombres ilustrados y resueltos con toda la fuerza de su espíritu, con todo el impulso de su corazón, que quisieron dar a su país prosperidad y bienestar, cultura y dignidad». 
A Ilustración española forma parte do movemento xeral europeo do século XVIII, pero tivo o seu aspecto individual: o seu acatamento absoluto e incondicional á monarquía tradicional e á Igrexa. A ciencia e mais o progreso non só son conciliables coa relixión, senón que son inseparables.

Como di J. Marías (1966: 270), a Inquisición impediu o pecado contra a fe por defecto, pero non por exceso: «los españoles no han dejado de creer en lo que hay que creer, pero han caído en creer muchas cosas indebidas». Quizais isto poida explicar que a Feijoo o ataque a clase segrar baixo a capa de beataría e relixión, mentres que o apoian e defenden os agostiños e mais os xesuítas, ademais dos seus irmáns en relixión e, mesmo, o Sumo Pontífice. Todo isto parece reflectir que ciencia e relixión van sempre da man no pensamento de Feijoo e de Sarmiento. Non obstante, o problema é moito máis complicado do que parece a primeira vista xa que, cando xorde contradición entre as crenzas da relixión e os descubrimentos científicos, a última palabra tena a fe, coa que ambos manteñen unha fidelidade intransixente $\mathrm{O}$ propio Feijoo constata: «Si la Experiencia y el Evangelio entrasen en oposición, yo daría un mentís a mis ojos y a mis manos para creer en el Evangelio» (1726-1740, 6: 122).

Sarmiento, ao igual que o seu egrexio mestre, exporá con rigor e con convicción as ideas que aboiaban no ambiente «manteniéndose constantemente dentro de las más severa ortodoxia». El mesmo faranos partícipes do seu catolicismo teimudo con estas frases contundentes: "Como Catholico, que soy, he captivado siempre y captivaré, mi Entendimiento, in obsequium Fidei. Como Religioso, libremente he sugetado desde mi niñez, mi voluntad y conducta, á mis legítimos superiores».

\section{VIDA E OBRA}

Benito Jerónimo Feijoo Montenegro naceu o 8 de outubro de 1676 en Casdemiro, preto de Ourense. Fillo primoxénito de familia nobre, a súa nenez pasouna entre Ourense, Casdemiro e Allariz. Entre os dez e os catorce anos permaneceu no mosteiro de Ribas de Sil. En 1690 renunciou ao morgado e ingresou como novizo bieito en Samos. Tomou o hábito en 1692. Despois cursou Artes e Teoloxía na Universidad de Salamanca. Logo dun breve paso polo mosteiro leonés 
de Eslonza, onde ensinou Teoloxía, trasladouse en calidade de «Lector de Artes» a San Salvador de Lérez (Pontevedra), onde ficou de 1701 a 1706. Alí tivo de alumno a Frei Martín Sarmiento. No curso 1708-1709 ensinou Teoloxía en Poio

Tras a estadía en Poio, os seus superiores destinárono ao mosteiro de San Vicente en Oviedo e alí permaneceu ata o día da súa morte. No ano 1709, á idade de 33 anos, doutorouse na devandita Universidade e opositou á cuarta cátedra de Teoloxía. Seguiu ascendendo no cursus honorum universitario ata acadar a cátedra de Prima de Teoloxía, sempre por oposición, aos 60 anos de idade. Xubilouse en 1739 e abandonou o maxisterio oral para concentrarse no ensaio escrito. Morreu en 1764 aos 88 anos. Os seus restos mortais fican soterrados na cidade de Oviedo.

Comezou a escribir cando tiña 50 anos. O seu primeiro libro impreso apareceu en 1725; nel trataba un asunto científico, pois era unha Apología del escepticismo médico, especialmente dirixida fronte á ciencia médica establecida. $\mathrm{O}$ libro suscitou de súpeto unha grande polémica, o que lle carrexou a fama literaria tanto en Europa coma en América. Con todo, a súa obra capital é o Teatro crítico universal, en oito tomos, que foron saíndo regularmente entre 1726 e 1739 aproveitando a súa xubilación como catedrático. Entre 1742 e 1760, publicou a súa segunda grande achega, os cinco volumes das Cartas eruditas. Os críticos tentaron rebater os seus escritos consonte ían saíndo do prelo, razón pola cal o rei Fernando VI ditou en 1751 unha «Real Orden» que prohibía a todo o mundo impugnar os escritos feijonianos "porque eran del real agrado». Cando se publicou o quinto volume das Cartas, Feijoo xa cumprira oitenta e cinco anos e en diante só mantivo correspondencia, tarefa que lle roubaba dous días semanais.

Esta é case toda a súa a biografía de frade. $\mathrm{O}$ anterior foi case bioloxía e o de despois, bibliografía, tanto a lida como a producida. Nun escrito anónimo, publicado en 1765 co gallo do seu pasamento, dise: «Siempre se le veía leyendo, siempre se le encontraba sentado con un libro en la mano. El que escribe esto puede testimoniar que jamás vio hombre alguno que ocupara diariamente tantas horas en la lectura como el Rvdmo. Feijoo en los años que tuve la dicha de tratarlo. Aún en las horas de comer tenía algún libro sobre el mantel». Ler, antes de escribir, durante 40 anos. Como logo se viu, tan longo ler tascando o freo na procura da súa hora que, afortunadamente el mesmo decretou chegada, logo de tanto esperala. O Pai Mestre esperou aos 50 anos e aínda así refírenos que houbo unha teima por parte de «muchos sujetos de mi sagrada religión, algunos de pri- 
mera magnitud, que han estado lidiando con mi cobardía sobre trabajar para el público [...]. Nadie desconfía de mis fuerzas más que yo mismo» (Teatro crítico, «Prólogo» ao tomo II). Os testemuños sobre a brillantez e claridade do seu estilo abundan xa entre os seus contemporáneos. Por exemplo, frei José Pérez, mestre xeral do Colexio de Oviedo, di:

Sus libros están escritos con tanta claridad, discreción y sutileza, siendo de materias tan distantes y tan distintas, que no parece que un ingenio solo puede alcanzar a tanto, y que crece y se aumenta en cada libro. Esto ha admirado en ellos hombres muy doctos: ver que habla en tantas facultades tan distantes e inconexas, con tanta penetración de sus puntos y materias, y con estilo tan elegante, tan claro, y tan natural, como si de cada una sola hubiese sido muchos años profesor. (Teatro crítico, «Aprobación» ao tomo IV)

O propio Feijoo indica no «Prólogo» ao tomo I: «quien quiera que examine este libro, fácilmente convendrá en que su autor posee perfectamente la ciencia de ganar con su voz los corazones». Emilia Pardo Bazán sinala: «[...] y sobre todo posee el don inestimable de hacerse amar, de prender al lector y no soltarle» (Pardo Bazán 1877: 28). Gregorio Marañón concorda coa mesma opinión ao afirmar que «tuvo para complemento de su eficiencia el arma de un lenguaje exacto y diáfono, verdadero promotor del estilo científico en castellano» (Marañón 1941: 143), e Marichal cualifica o Pai Mestre de home de sensibilidade comunicativa que aspira a que os seus criterios sexan temporalmente operantes e como el mesmo di: «sacrifica su pluma al bien común» (Marichal 1971: 148).

A lectura de Feijoo comeza a facerse por curiosidade ou por obriga e remata polo pracer desa compañía persoal que xorde dos seus escritos como nun coloquio improvisado e, case diría, de primeira intención intranscendente. Baseados nunha implacable estrutura lóxica, os seus discursos fluían dando corpo a unha idea forte e non trivial. Unha linguaxe severa, cinguida e rica constituía o vehículo formidable do seu pensamento, á que un ritmo e unha cor especiais e, ás veces, un lirismo fondo dotaban de gran forza persuasiva.

Baixo estas premisas o éxito das súas publicacións foi fulminante. $\mathrm{O}$ mesmo Feijoo prevé atrancos cos que se vai atopar: «cargarán sobre mí injurias y dicterios» (Teatro crítico, «Prólogo» ao tomo I). Con todo, o público agardaba diante da portería do convento madrileño de San Martín para mercar os sucesivos volu- 
mes. Feijoo escribe: «Allí vienen a buscarlos de todas partes, siendo su despacho tan acelerado cual se manifiesta por el cuantioso número de ejemplares que se sacan» (Teatro crítico, «Prólogo» ao tomo V). Un cálculo de mediados do século XIX asegura que se levaban vendidos medio millón, o que contrasta nidiamente coa escasísima demanda de libros do país (Rodríguez Ennes 2000: 346).

Á súa asombrosa difusión contribuíu, sen dúbida, o espallamento das ideas iluministas en Iberoamérica. Falouse, con certa esaxeración, dos barcos da Ilustración que levaban, ao propio tempo que os produtos, os libros, as novas e as ideas da Europa culta (Ramón de Basterra 1941: 39-40). Con todo, na miña opinión, en América, ao igual que en España, e máis aínda que en España, o que se entendía por Ilustración só tiña unha afastada vinculación co movemento enciclopedista francés. Non se trataba de «aplastar lo infame», senón de elevar o nivel cultural da poboación permanecendo fieis no esencial ao catolicismo tradicional, ao que soamente se procurou adaptar as esixencias do mundo moderno: menos metafísica e máis física.

A obra do Padre Feijoo, divulgador talentoso, semella ser moito máis meditada e lida que a de Rousseau (Rodríguez Ennes 2002: I, 190). Como apuntou Maravall:

Feijoo no es sólo un tema español, sino tema común a todo el área de cultura en lengua española. En América, Feijoo ocupa la misma posición y desempeña el mismo papel que en la Península. Es leído e influye como ningún otro en el pensamiento del siglo XVIII y el carácter polémico de su obra es paralelo en ambos lados del Océano, dando lugar a campañas semejantes y trayendo consecuencias similares a la penetración del pensamiento moderno. (Maravall, 1964: 349)

Feijoo vive a cabalo dos séculos XVII e XVIII, «época de transición, decadencia y mal gusto, en el que el país estaba en un estado de atraso y postración» (La Fuente 1863: VII). Xa en pleno século XX, J. M. Cossío cre que, en definitiva, hai que chegar á conclusión de que os derradeiros anos do século XVII e primeiros decenios do XVIII representan «el bache más profundo de la progresión de la vida social y del adelantamiento intelectual españoles» (Cossío 1941: 199). E tal é a nosa opinión. Se, en rigor, non se pode falar dun «misérrimo estado» da cultura española da época, si é xusto sinalar este alongado «bache» que se espalla, máis ou 
menos, desde a segunda metade do reinado de Carlos II ata ben avanzado o de Felipe V. Ante as posibles dúbidas disto, abonda con observar que o mesmo Feijoo, coa plena mantenza dos seus dotes intelectuais, viviu unha gran parte deste «bache» histórico en recollido silencio, que non quebrou ata que as condicións políticas foron máis doadas para o labor literario e científico: aos cincuenta anos da súa vida.

É, sen dúbida, un pensador crucial, como correspondía á súa época; un pensador que separa dous tempos porque ten, xa que logo, pegadas do pasado e indicios do vindeiro. Como crítico vai saber o debe e o haber para levalos á conta nova; esta é, dende logo, unha das súas significacións fundamentais. Mais hai outra que ordinariamente se esvae e que é mais transcendente: Feijoo vai tentar esta anovamento sen afastarse da cerna do pensamento español. Isto é o que o distingue dos enciclopedistas que se amosan como herdeiros seus. E para iso hai moitas razóns. En primeiro lugar, Feijoo non foi contemporáneo, senón en época moi serodia da súa vida, dos xenuínos enciclopedistas franceses (o cumio de Voltaire, Montesquieu e Rousseau acadouse sobre mediados do século XVIII, cando Feijoo xa tiña publicado todo o seu Teatro crítico); en segundo lugar, a fortísima formación relixiosa que os seus hábitos e os longos anos de maxisterio teolóxico permitían supor, se non tivésemos o testemuño da súa propia obra (Sánchez Agesta, 1941: XIV).

\section{ACOUTACIÓNS XURÍDICAS}

Onde a crítica dos ilustrados se manifestou con maior intensidade e amplitude foi no sector penalista, en paralelo co cambio de perspectiva das relacións entre poder político e súbditos. Os ilustrados, a partir de supostos utilitaristas e humanitarios, elaboraron unha concepción nova da pena que, rexeitando a crueldade dos sistemas vixentes, apostaba pola certeza e pola proporción xustas como os medios disuasorios máis idóneos para afastar do delito e atribuíanlle á sanción a función de emendar o culpable, ademais de facerlle expiar o seu erro. Deste xeito adquiriu unha gran relevancia o debate sobre a abolición dalgunhas penas, como as infamantes e mais a capital, que semellaban para moitos contraproducentes en relación cunha consideración omnímoda da utilidade xeral. A visión que primaba 
o aspecto da prevención sobre a represión quedaba tamén reforzada —ás vecescoa proposta de medidas de carácter social que diminuíran a tendencia a delinquir mediante a mellora das condicións económicas e culturais da poboación.

Todo o aparato da xustiza penal está encamiñado a facer o máis eficaz posible o labor dos xuíces. O proceso xudicial — coa tortura como ferramenta indagatoria-, a indefinición das leis, a falta de garantías procesuais, o amplo arbitrio deixado en mans dos xuíces para impoñer as penas, o feito de que estes participasen nas penas pecuniarias, a ausencia de consideracións que xustificasen as sentenzas perseguían favorecer as accións da xustiza e aumentar o seu celo na persecución dos infractores das leis. Pero, pola estrutura de privilexios da sociedade estamental, a xustiza real ten na nobreza e na Igrexa un límite para as súas accións. Ambos os dous estamentos conservan un alto grao de autonomía, teñen foros particulares e unha ampla marxe para as actuación ilegais. As desigualdades e mais as distancias que existen entre os grupos sociais son as mesmas que se manteñen entre as leis e a súa aplicación.

A tortura tiña unha importancia desmedida como medio de coñecemento da existencia de culpabilidade, constituía un instrumento coercitivo que perseguía obter a confesión do reo. Todo este conxunto de soportes está construído co fin de acadar a proba perfecta: a confesión do acusado. Pois, en efecto, se esta non se produce espontaneamente, a existencia de indicios contra un sospeitoso permitíalle ao xuíz sometelo a tortura ad eruendam veritatem, dado que só se consideraba desvelada a verdade cando o atormentado confesaba a súa culpabilidade no acto do tormento e ratificaba a súa confesión despois da tortura, pero non se o torturado sostiña, antes, durante e despois do tormento, a súa inocencia.

Contra a tortura escribírase bastante desde San Agustín e Luís Vives, pero é o P. Feijoo quen, por primeira vez, emprega argumentos de utilidade para poñer en dúbida a súa eficacia. Así, advirte que hai persoas tan débiles que, ao primeiro tormento, confesan o que se lles pide aínda que sexa falso e outras tan pertinaces que seguen negando a verdade aínda que se lles apliquen os máis duros tormentos. Xa a décima das Paradojas políticas y morales de Feijoo rezaba así: La tortura es medio falible en la inquisición de los delitos e nela, entre outras cousas, sinalábase:

Es innegable que el no confesar en el tormento, depende del valor para tolerarlo. Y pregunto, ¿el valor para tolerarlo depende de la inocencia del que está puesto en la 
tortura? Es claro que no, sino de la valentía del espíritu y robustez de ánimo que tiene. Luego la tortura no puede servir para averiguar la culpa o inocencia del que la está padeciendo [...]. Parece, pues, que igualmente peligran en la tortura los inocentes que los culpables. ¡Terrible inconveniencia! Lo peor es que no es el peligro igual, sino de parte de los inocentes mayor. Diranme que ésta es una nueva paradoja, Confiésolo, pero si no me engaño, verdaderísima. (Obras escogidas de Feijoo, en BAE, LVI: 289 e ss.)

Con razón e oportunidade observa D. Vicente de la Fuente que o mérito de Feijoo radica en publicar a súa Paradoja sobre a tortura no ano 1734, anticipándose deste xeito en varios lustros á polémica que entre os xuristas españois desencadeou a xa comentada «cuestión do tormento» (Martínez Risco 1973: 68). Con todo, o pensamento do mestre dista moito de ser claro e tallante a este respecto e, sobre todo, amósase moi lonxe do do seu discípulo e amigo Frei Martín Sarmiento. Na Balanza de Astrea o recta administración de Justicia declara que non lle horroriza que na India ás falsas testemuñas lles corten os pés e as mans e, tampouco, que en Berna un maxistrado os fixese ferver en aceite. A este respecto indícanos Concepción Amor:

En una época en que el tormento como procedimiento judicial era cosa habitual corrientísima desde muchos siglos antes, era también bastante natural que no se sintiera con la intensidad que se siente hoy lo ofensivo y vejatorio que resulta a la dignidad humana. Por eso, Feijoo no tiene ni una sola palabra condenatoria del tormento en este sentido humano-social, sino que solamente lo encuentra absurdo porque resulta contraproducente para lograr el fin que persigue. (1950: 289)

Silva Melero é aínda máis crítico nesta cuestión co pensamento feixoniano:

Sin embargo, el P. Feijoo, cuando trata de temas penales, ni se adelantó a la época, ni captó el ambiente que presagiaba tempestad y casi puede afirmarse que, en la ruta de la humanización penal, quedó rezagado en relación a más de uno de sus antecesores españoles e, incluso, de algún contemporáneo como el P. Sarmiento, su sombra, como dice el Dr. Marañón. Esto, naturalmente, no quiere decir que el P. Maestro no sintiera el problema penal ni menos que su espíritu iluminado por la caridad no vibrara ante el espectáculo de un sistema transido de crueldad. Sin embargo, ya habían surgido en 
España antes que Feijoo apareciera protestas contra el tormento y se había propuesto la humanización de las prisiones, tendencia nacida de la piedad cristiana, en el pensamiento de Cristóbal de Chaves, Bernardino de Sandoval y Cerdán de Tallada. (Silva Melero 1956: 35)

Insiste en consideracións semellantes Concepción Arenal cando sostén que Feijoo tiña fame e sede de xustiza pero que, pola contra, non tiña da xustiza en materia criminal unha noción exacta, e que nisto, lonxe de se adiantar á súa época, lle paga un malpocado tributo incorporándose a ela. E engade: "no por ignorancia del asunto, pues no era extraño al estudio penal, sino por sus exageradas ideas de la perversión de la naturaleza humana, y a pesar de ser compasivo y caritativo, como lo acredita su vida, se nos presenta duro cuando se trata de penar a la delincuencia» (Arenal 1989: 27).

O problema da pena de morte é o que suscitou máis controversias e o que, sobre todo desde o Século das Luces, dividiu máis as opinións. Seguramente ningún medio penal foi máis ardentemente combatido nin, por outra parte, defendido coa máis firme convicción, nin máis universalmente aplicado. Como sinalou Rossi: "La historia nos enseña que el uso de la pena de muerte ha sido universal; se la encuentra establecida en todas las épocas y en todos los pueblos».

$\mathrm{O}$ propio Feijoo, malia que non se pode dicir que fose un defensor sen concesións dela, propugnaba o seu mantemento. Vexamos sobre este punto o pensamento do sabio de Casdemiro:

Dirásme acaso que esos daños no se remedian con que ese hombre muera, y así su muerte no hace más que añadir esta nueva tragedia a las otras. No se remedian esos daños; pero se precaven otros infinitos del mismo jaez. Los delitos perdonados son contagiosos; la impunidad de un delincuente inspira a otros osadía para serlo; y al contrario, su castigo, difundiendo una aprensión pavorosa en todos los mal intencionados, ataja mil infortunios. Ya que no puedes, pues, estorbar la desdicha de aquellos inocentes en quienes ya está hecho el daño, precave la de otros innumerables.

Á vista do exposto, non podemos concordar con Martínez-Risco cando afirma que «los textos en que apoya - a pena de morte- afloran serias dudas que pudieran interpretarse como vacilaciones o, al menos, debilidad en su actitud al respecto» 
(1993: 61) e conclúe que «los conceptos que emite al final de esa Paradoja Tercera dan paso a la creencia de que en el fondo de esa duda latía una idea abolicionista». Pola contra, amósase moito máis atinado á hora de captar o sentir feixoniano verbo da pena capital López Peláez, quen opina coa súa retórica decimonónica: "Con tener Feiioo ideas tan originales, tan independientes y tan atrevidas, y haber dirigido los formidables golpes de la demoledora piqueta de su crítica contra opiniones las más arraigadas y cimentadas más profundamente, se detuvo ante la pavorosa esfinge de la pena capital y quemó incienso en sus altares, en los cuales depositó el homenaje elocuente de su adhesión» (López Peláez 1901: 157).

Pola nosa parte, entendemos que o feito de que Feijoo se encadre nas filas dos apoloxistas da pena capital e que sexa adversario do abolicionismo nin lle engade gloria nin isto se pode erixir de xeito apriorístico nun motivo de crítica per se, sobre todo de termos en conta que, como dixemos, moitos dos espíritos senlleiros da época amosaban a súa inclinación en favor da pena máxima. Feijoo só se limita a seguir a tese da prevención xeral defendida naqueles tempos por Montesquieu e Rousseau. Ninguén mellor ca Concepción Arenal para plasmar a esencia do sentir feixoniano: «La escuela a que pertenecía Feijoo no veía más que el derecho de la sociedad; el del reo desaparecía muchas veces en teoría y con mayor frecuencia aún en la práctica; el culpable era una criatura vil, infame, detestable, incorregible, objeto de desdén o de horror, y medio de escarmiento...».

\section{GALEGUIDADE}

Como é sabido, a marxinalidade institucional do galego vén desde moi atrás. A perda da independencia política e a conseguinte inclusión de Galicia no reino castelán-leonés impúxolle o monolingüismo. Mesmo Afonso X, cunha corte onde triunfaba o galego literario, ordenou redactar en castelán todos os seus ordenamentos xurídicos de aplicación exclusiva en Galicia: foros, privilexios, sentenzas (Rodríguez Ennes 2005: 128). Por maior abastanza, a Igrexa e os seus bispos, verdadeiros representantes e oíntes da Coroa, dende o século XIV serán foráneos e ignorantes da lingua galega (Ferro Ruibal 1987: 23-24). Tamén desde esa centuria os escribáns de Galicia comezan a empregar o castelán nos seus documentos, lingua que irá desprazando paseniñamente o galego como lingua escrita 
da Administración. O proceso da perda do galego oficial completarase a partir de 1480, data de creación da Real Audiencia, aínda que para Filgueira Valverde (1993: 346) «nunca existiu a suposta pragmática prohibitiva de dona Isabel e don Fernando» e engade: «a enchente de personaxes foráneos na vida pública e mesmo nas familias podentes ven influir negativamente».

Desta multisecular marxinación da lingua galega faise eco Sarmiento cunhas palabras tan expresivas que non nos resistimos a transcribir:

No pocas veces he pensado en cuál ha sido la causa de que en Galicia se haya introducido el uso y el abuso de escribir en castellano lo que antes se escribía en latín o en gallego [...]. No habiendo precedido ni concilio ni cortes ni consentimiento uniforme de los gallegos para actuar, comerciar en lengua castellana ¿quién lo introdujo? La respuesta está patente que Galicia llora y llorará siempre: no los gallegos, sino los no gallegos que a los principios del siglo XVI inundaron el reino de Galicia, no para cultivar sus tierras, sino para hacerse carne y sangre de las mejores y para cargar con los más pingües empleos así eclesiásticos como civiles. Esos han sido los que por no saber la lengua gallega ni por palabra, ni por escrito, han introducido la monstruosidad de escribir en castellano para los que no saben si no el gallego puro. Esta monstruosidad es más visible en los empleos eclesiásticos. No sé como toleran los obispos que curas, que no son gallegos ni saben la Lengua, tengan empleo ad curam animarum; y sobre todo la Administración del Santo Sacramento de la Penitencia. ¿Qué es el coloquio de un penitente rústico y Gallego, y un confesor no Gallego, sino un entremés de los Sordos? (Sarmiento 1997: 729)

Fronte a esta postura de defensa da nosa lingua por Sarmiento, sen ambaxes e radical, algunhas opinións, como a de Otero Pedrayo (1964), cuestionan a galeguidade de Feijoo: «Feijoo es insensible a las diferencias regionales y contempla los estados como grandes bloques unidos [...]. Feijoo aparece intolerante y, digámoslo de una vez, ingrato y rudo con la tierra nativa; verdad que sin dar el nombre de la suya, pero tampoco sin ninguna atenuante». Como se pode apreciar, o dito por D. Ramón verbo de Feijoo non ten solta de folla; e o escrito está, aínda que en 1973 preferiu subliñar os aspectos máis galegos e incluso galeguistas de Feijoo, que tamén están aí... O preito da galeguidade maior, menor ou nula de Feijoo segue aberto. Con todo, hai un dato rexamente obxectivo: os primeiros vinte e dous anos da vida do noso bieito transcorreron en Galicia, e como di 
Blanco-Amor citando a Rilke: «la patria del hombre es su infancia». En palabras do autor da Esmorga, «esto es decisivo» e engade "Con retórica o sin ella, cualquier gallego que se haya pasado los veinte primeros años de la vida en su tierra, a dónde quiera que luego vaya y durante el tiempo que esté, será para siempre un emigrante» (Blanco-Amor 1984: 20). O escritor ourensán, non obstante, semella contradicirse cando, facendo referencia á marcha de Feijoo a Oviedo, di textualmente: «donde se aquerencia ya para siempre».

$\mathrm{Na}$ nosa opinión, non cómpre adoptar unha postura inequívoca diante desta sobranceira cuestión. No tocante ao afirmado por Blanco-Amor, non é o mesmo vivir vinte anos mergullado no berce familiar e veciñal, falando a nosa lingua decotío, que pasar a meirande parte dese tempo tras os rexos muros pétreos dun mosteiro, lonxe do mundanal ruído, afastado dos paisanos e falando e escribindo absolutamente todo en latín ou castelán. Polo que atinxe á postura, primeiro tallante e logo máis ecléctica, de Otero Pedrayo, cómpre dicir, pola miña banda, que na súa, ao meu xuízo hipervalorada, biografía do Padre Feijoo escrita en 1973, agás pura retórica non atopo ningún apoio textual no que o trasalbés basee a súa trocante postura. Dito isto, penso que o mellor para saír deste atranco é pescudar nas obras de Feijoo algunhas referencias que contribúan a iluminarnos e, concretamente, constátase unha rexa defensa da lingua galega no discurso XVI «Paralelo de las lenguas» do tomo I do Teatro crítico universal:

Entre lo cuatro dialectos de la lengua latina: español, italiano, francés y lusitano en este se debe incluir la lengua gallega como en realidad indistinta de la portuguesa. Que la lengua lusitana o gallega se debe considerar dialecto separado de la latina y no subdialecto o corrupción de la castellana se prueba, a mi parecer, con evidencia del mayor parentesco que tiene aquella con la latina. Para quien tiene conocimiento de estas lenguas no puede haber duda de que, por lo común, las voces latinas han degenerado menos en la galaico portuguesa. Esto no pudiera ser si la lengua de gallegos y portugueses fuese corrupción o subdialecto de la castellana, siendo cierto que con cuantas más mutaciones se aparta una lengua de la fuente, tanto más se aleja de la pureza de su origen.

Así as cousas, dou por rematada a discusión sobre a galeguidade de Feijoo. 


\section{REFERENCIAS BIBLIOGRÁFICAS}

Amor, Concepción S. (1950): Ideas pedagógicas del Padre Feijoo, Madrid.

ARenal, Concepción (1887): Juicio crítico de las obras de Feijoo, Madrid.

BASTERRA, Ramón de (1941): Los navios de la Ilustración, Madrid.

Blanco-Amor, Eduardo (1984): «Prólogo y selección de textos», en Padre Feijoo. Obra Selecta, Santiago de Compostela, 9-82.

Cossío, José María de (1941): Introducción a la lectura de las obras del P. Feijoo, Madrid.

Feijoo y Montenegro, Benito Jerónimo (1726-1740): Teatro crítico universal, Madrid.

Feijoo y Montenegro, Benito Jerónimo (1742-1760): Cartas eruditas y curiosas, Madrid.

Ferro Ruibal, Xesús (1987): A Igrexa e a lingua galega, Santiago de Compostela.

Filgueira Valverde, Xosé (1993): «O galego na documentación oficial», en Xosé Ramón Barreiro Fernández

/ Pablo González Mariñas (coords.), Historia da Administración Pública, Santiago de Compostela, 345-351.

HERR, Richard (1988): España y la revolución del siglo XVIII, Madrid.

Kant, Immanuel (1784): Was ist Aufklärung, Berlín.

LÁzaro Carreter, Fernando (1963): Significación cultural de Feijoo, Oviedo, Cuadernos de la Cátedra Feijoo.

LOCKE, John (1690): An essay concerning human understanding, Londres.

López Peláez, Antolín (1898): «Un predecesor de Becaria», Revista Contemporánea, 52, 413 ss.

Marañón, Gregorio (1941): Las ideas biológicas del Padre Feijoo, Madrid.

Maravall, José Antonio (1991): Estudios de la historia del pensamiento español (siglo XVIII), Madrid.

Marías, Julián (1966): «La España posible en tiempos de Carlos III», en Obras Completas, Madrid, 270 ss.

Marichal, J. (1971): La voluntad de estilo, Madrid.

Martínez-Risco y Macías, Sebastián (1973): Las ideas jurídicas del Padre Feijoo, Ourense.

Otero Pedrayo, Ramón (1964): «Na procura do íntimo mestre Feixóo», Grial, 4, 159-168.

Otero Pedrayo, Ramón (1972): El Padre Feijoo. Su vida, doctrina e influencias, Ourense.

Pardo BazÁn, Emilia (1877): Estudio crítico de las obras de Feijoo, Madrid.

PARdo BAZÁn, Emilia (1888): «Feijoo y su siglo», en De mi tierra, A Coruña, 141-217.

Rodríguez Ennes, Luis (1999): Aproximación a la historia jurídica de Galicia, Santiago de Compostela.

Rodríguez EnNes, Luis (2005): Fray Martín Sarmiento y el mundo del derecho, Santiago de Compostela.

Rossi, Pellegrino (1883): Derecho Penal, Madrid.

SÁnChez Agesta, Luis (1941): «Estudio preliminar sobre la significación del P. Feijoo en la historia del pensamiento político español», en F. B. J. Feijoo. Teatro crítico universal y Cartas eruditas. Selección, Madrid. Sarmiento, Martín (1732): Demonstración crítico-apologética del Theatro Crítico Universal, Madrid.

SARMiento, Martín (1758): Elementos Etymológicos según el Método Euclides para averiguar por la Analógica alteración de la Lengua Latina y en todos sus dialectos, el primitivo origen de muchísimas voces, Madrid.

Sempere y GuARINOS, Juan (1785-1789): Ensayo de una biblioteca española de los mejores escritores del reinado de Carlos III, Madrid.

Silva Melero, Valentín (1956): «La faceta criminal en el pensamiento del P. Feijoo», Anuario de Derecho Penal y Ciencias Penales, 9, 33-41. 


\section{OLLADA CRÍTICA SOBRE A OBRA DE FEIJOO DE DUAS INTELECTUAIS GALEGAS: CONCEPCIÓN ARENAL E EMILIA PARDO BAZÁN}

Xosé Ramón Barreiro Fernández

Universidade de Santiago de Compostela Real Academia Galega 

Despois da ruidosa polémica suscitada no século XVIII pola publicación da súa obra parecía que, por fin, se impoñía o xuízo e a cordura cando Sempere y Guarinos $^{1}$ (1785) escribiu que, a comezos do século XVIII, a ciencia en España estaba sumida en espesas tebras cando a aparición do Teatro crítico as fixo retroceder e chegou, de novo, a claridade.

Xa nos comezos do século XIX, Laborde² fai no seu coñecido «Itinerario» unha loanza xusta e ata xenerosa da obra do bieito galego. Blanco White, tan hipercrítico na valoración dos intelectuais españois, recoñece que a lectura das obras de Feijoo lle fixo mudar radicalmente os seus xuízos e, por iso, o tiña como unha das glorias de España ${ }^{3}$. Pero fixémonos que ambos os dous xuízos foron escritos e publicados no estranxeiro. En España, os críticos escatimaban os eloxios ou, mesmo, o silenciaban, actitude que non era exclusiva dos radicais defensores da tradición senón tamén dos renovadores, se é certo o xuízo atribuído a Lista y Aragón, para quen había que erguer unha estatua a Feijoo e logo queimar diante dela toda a súa obrá .

De feito e ata 1868, cando Feijoo entra forzosamente na gran polémica sobre a Ciencia en España, os escritos sobre o bieito galego foron escasos e mediocres 5 : rutineiras biografías para coleccións colectivas ${ }^{6}$; o curso encomendado a Alcalá Galiano no Ateneo de Madrid no ano 1845 sobre a historia da literatura española, francesa, inglesa e italiana do século XVIII, no que Feijoo aparece con máis sombras que luz; a desmedrada introdución de Vicente de la Fuente na publicación das obras de Feijoo para a Biblioteca de Autores Españoles, e o entusiasta, aínda

1 Sempere y Guarinos, Juan (1785): Ensayo de una biblioteca española de los mejores escritores del reinado de Carlos III, Madrid, Imprenta Real, I, 15.

2 Laborde, Alexandre-Louis-Joseph de (1808): Itinéraire descriptif de l'Espagne, et tableau élémentaire des différentes branches de l'administration et de l'industrie de ce Royaume, Paris, Chez H. Nicolle et Lenormant, $5 \mathrm{v}$.

3 Leocadio Doblado [pseudónimo de José María Blanco White] (1822): Letters from Spain, By don Leocadio Doblado, Londres.

4 Alude Menéndez Pelayo «al chiste de la estatua» que Lista divulgaba entre os seus amigos e discípulos. Vid. Menéndez Pelayo, Marcelino (1882): Historia de los heterodoxos españoles, Madrid, Imp. de F. Maroto e hijos, III, 78.

5 Para coñecer a evolución da valoración da obra de Feijoo é imprescindible acudir á monumental obra de Ramón Otero Pedrayo (1972): El Padre Feijoo. Su vida, doctrina e influencias, Orense, Instituto de Estudios Orensanos Padre Feijoo.

6 Diccionario Histórico ó Biografía Universal compendiada, Barcelona, 1832; Roca y Corner, J. (1847): Vida de Feijoo. Biografia Eclesiástica Completa, Barcelona. 
que pouco crítico, discurso de apertura do curso na Universidad de Oviedo no ano 1857 do profesor José María Anchóriz7.

Polo que respecta a Galicia, foron os provincialistas (a primeira xeración galeguista) os que se decataron da extraordinaria importancia de Feijoo e Sarmiento para a construción dun imaxinario liberal galeguista. Por iso, Faraldo, o líder do grupo, recuperou a Feijoo ${ }^{8}$ como paradigma da modernidade científica e española e expoñente do xenio galego. Pero foi Murguía ${ }^{9}$ quen mellor comprendeu a transcendencia da obra de Sarmiento e Feijoo na reconstrución do proceso identitario; Sarmiento pola súa importantísima contribución ao estudo do galego e Feijoo como o expoñente máis lúcido e xenial da contribución que á cultura española se fai dende a periferia.

Con estes antecedentes, compréndese que o claustro do Instituto de Ourense alertase, o 21 de outubro de $1875^{10}$, as autoridades para que se celebrase solemnemente o segundo centenario do nacemento do P. Feijoo. Mobilizadas as autoridades e forzas vivas da cidade, proxectaron diversos actos e a dedicación dunha estatua ao P. Feijoo. Entre estes actos foi, sen dúbida, o máis destacado a realización dun Certame, economicamente ben dotado (con 4000 reais), para o estudo crítico da obra do sabio bieito, tal e como xa expuxemos nun artigo ao que remitimos ${ }^{11}$. O proxecto da estatua cumpriuse, ao fin, no ano 1887 con novas celebracións ${ }^{12}$.

Tres foron os estudos presentados ao Certame de Ourense en 1876: o do catedrático da Universidad Central Miguel Morayta, do que prescindimos pola inter-

7 Anchóriz, José María (1857): Biografía y juicio de las obras que escribió el Ilustrísimo y Reverendísimo Padre Fray Benito Gerónimo Feijoo, Oviedo, Imp. y Lit. de Brid, Regadera y Comp.

8 Faraldo, Antolín (1843): «Feijóo. Su espíritu filosófico e influjo en la civilización española», El Recreo Compostelano (Santiago), 133-138.

9 Murguía, Manuel (1862): Diccionario de Escritores Gallegos, Vigo, Imp. Compañel, 199-212. Consideraba a Feijoo «la primera inteligencia que produjo nuestro país» (Idem, p. 206) e nas súas obras «se nota la dulzura y sentimiento propio de la raza a que pertenecía» (Idem, p. 205).

${ }^{10}$ El Heraldo Gallego (Ourense), 21-X-1875.

11 Barreiro Fernández, Xosé Ramón (2003): «O estudio crítico das obras do P. Feijóo de Pardo Bazán, Concepción Arenal e Miguel Morayta. O certame de 1876”, La Tribuna. Cadernos de Estudios da Casa Museo Emilia Pardo Bazán, I: 1, 47-96.

12 Pardo Bazán pronunciou o discurso para solemnizar a inauguración da estatua dedicada en Ourense ao P. Feijoo o 10-IX-1887 e publicouno en 1888 co título de «Feijoo y su siglo», en De mi tierra, A Coruña, Tipografía de La Casa de Misericordia, 141-219. 
pretación sectaria que fai da obra de Feijoo ${ }^{13}$; o de Concepción Arenal, «Juicio crítico de las obras de Feijoo»" ${ }^{14}$ e o de E. Pardo Bazán, «Estudio crítico de las obras del P. Feijoo» ${ }^{15}$. As diverxencias críticas proceden dos principios filosóficos que sustentan as autoras. Nos dous casos illaron a obra do P. Feijoo do contexto en que se producira, disecaron os seus discursos e procuraron resitualo no contexto dunha sociedade, a dos anos do Sexenio, no que unha xenerosa liberdade de pensamento permitiu que agromasen ideoloxías alternativas ao discurso tradicional.

Feijoo, canda a súa obra, converteuse nun obxecto de especulación intelectual. Con estas dúas obras non avanza nin un milímetro a investigación sobre o bieito galego, nin se procuran novas fontes nin se afonda nas súas ideas básicas. $\mathrm{O}$ único que lles interesaba a ambas as intelectuais galegas era se as ideas de Feijoo iluminaban unha nova vía para a interpretación do «ser» de España ou se foi quen consolidou a auténtica tradición depurándoa daquelas contaminacións perturbadoras da cultura tradicional. Por iso interesa moito fixar as dúas ideoloxías que determinan os xuízos sobre a obra de Feijoo.

\section{CONCEPCIÓN ARENAL E FEIJOO}

O pensamento social de Concepción Arenal inscríbese no liberalismo máis ortodoxo. A sociabilidade vén predeterminada pola natureza e por iso a división por clases é o gonzo de toda a vida social. As clases fundaméntanse na explotación dunhas sobre outras e cando se clama contra tal explotación non se comprende a

13 Morayta y Sagrario, Miguel: El Padre Feyjoó y sus obras, Valencia (s.a.), probablemente impreso en 1912 na imprenta de F. Sempere. Morayta pretende facer derivar da obra do bieito galego o alento de liberdade precursor do primeiro liberalismo español. Feijoo sería o pai de todo o radicalismo intelectual e mesmo político do século XIX español.

14 Arenal, Concepción (1877): «Juicio crítico de las obras de Feijoo», Revista de España (Madrid), LV, 110-117, 187-226 e 398-410; LVI, 348-365, e LVII, 174-201. Reeditado parcialmente en 1966 na Antología popular, selección e prólogo de Eduardo Blanco-Amor, Bos Aires, Ed. Galicia del Centro Gallego de Buenos Aires.

15 Pardo Bazán, Emilia (1877): «Estudio crítico de las obras de Feijoo por la Señora Doña Emilia Pardo Bazán», en Certamen Literario en conmemoración del Segundo Centenario del Nacimiento de Fray Benito Jeronimo Feijoo, autor del Teatro Crítico Universal, celebrado en Orense el 8 de octubre de 1876: obras premiadas, Madrid, Tipografía y estereotipia Perojo, 1877. 
inevitabilidade xa que «el problema no consiste en que los fuertes no abusen de los débiles, sino en que no haya débiles o haya pocos» ${ }^{16}$.

Como é posible nestas circunstancias conseguir a harmonía social que será o obxectivo principal da súa vocación? Non a través do Estado, que debe permanecer neutral e só actuar en situacións extremas (liberalismo ortodoxo radical), senón por outros medios. O primeiro deles é o fortalecemento das clases medias:

El grande elemento de fuerza, de inmortalidad de nuestra civilización, está en las clases medias, distantes de los extremos, que piensan y trabajan, compuestas de diferencias que se armonizan, de fuerzas que se equilibran, de desigualdades que no son esenciales; el gran peligro de nuestra civilización está en las clases extremas, en las diferencias que no pueden armonizarse sino para el mal, en las fuerzas cuya tendencia es a romper todo equilibrio; en todo género de miserias, explotables y explotados por todo género de opulencias ${ }^{17}$.

O segundo medio que empregar é a utilización dunha ideoloxía moral e relixiosa que propugne esta harmonía social entre clases tan distantes. E iso lógrase tanto a través dunha ideoloxía e do papel activo da intelectualidade como mediante unha acción constante en favor dos desfavorecidos, que foi a súa vocación persoal, exercida ás veces ata o heroísmo. O que rexeita é a revolución por ser un atentado contra a propia natureza.

Neste sinxelo esbozo do seu pensamento ${ }^{18}$ emerxe a responsabilidade social dos intelectuais, que poucas veces asumen a súa obrigación de intermediar na dialéctica social ata conseguir a harmonía social. Con frecuencia, ocultan as grandes

16 Arenal, Concepción (1997): «La igualdad social y política y sus relaciones con la libertad (1898)», en Celia Pereira Porto, A aportación de Concepción Arenal no marco do estado liberal español, A Coruña, Deputación Provincial, p. 97.

${ }^{17}$ Arenal, Concepción (1997): «El pauperismo», en Celia Pereira Porto, op. cit., p. 98.

18 En moitas das súas páxinas, Concepción Arenal mestura a pura racionalidade da súa teorización con elementos voluntaristas que non axudan a interpretar o pensamento. Por exemplo, o seu concepto da «moral» parece ser un concepto unívoco, cando conforme a súa concepción da sociedade e da autonomía das clases sociais debería aceptar que cada clase ten a súa propia moral e adecuarse a ela. Tampouco queda claro cando o Estado debe intervir na cuestión social. O feito de defender o principio da autonomía das clases e, ao mesmo tempo, a obrigación do Estado en propiciar a harmonía social deixa un amplo campo sen discernir. Ademais disto, a utilización da «caridade» como mecanismo social de harmonía pode entenderse nunha concepción tan racionalista que por si mesmo debería ser capaz de resolver os conflitos sen necesidade de acudir ao voluntarismo. 
diferenzas de clases, os abusos dunha minoría opulenta e a escravitude dos pobres. Servidores dunha clase á que pertencen, renuncian a denunciar os abusos sociais.

Precisamente, este é o obxectivo do seu estudo sobre Feijoo. Clérigo privilexiado, famoso polas súas obras, cun evidente peso social no seu tempo, seguiu tamén os ditados da intelectualidade contemporánea criticando só aqueles aspectos máis externos, pero silenciando as causas da opresión, salvando en todo momento tanto a Igrexa, á que pertencía, como a monarquía, que tan pródiga foi con el. Por iso é moi difícil entender que o xuízo formulado por Concepción Arenal non sexa un retrospectivo axuste de contas.

Sería en certa maneira inútil buscar unha correlación entre o discurso de C. Arenal e a súa militancia política. Naceu e creceu nunha familia liberal. Casou no ano 1848 con Fernando García Carrasco, tamén liberal, e os dous colaboraron no xornal liberal La Iberia; mantén unha sólida amizade con Salustiano Olózaga e foi íntima amiga de Juana de Vega, condesa de Espoz y Mina, quen no seu testamento lle deixa un importante legado para ela e os fillos. Toda a súa personalidade se move, pois, nun contexto político liberal. Pero sorprendentemente, Concepción Arenal elabora un discurso completamente á marxe da filosofía liberal do seu partido. Onde os liberais destacan a soberanía nacional como eixe central, C. Arenal remarca o papel fundacional do plan divino na orixe e conformación da sociedade. Onde o pensamento liberal salienta o principio da laicidade para corrixir os desequilibrios sociais do absolutismo, C. Arenal defende que a relixiosidade é o motor central do proceso sociolóxico e histórico. $\mathrm{E}$, finalmente, cando os liberais deseñan un modelo de Estado centralista, capaz de cambiar radicalmente as estruturas da orde social, C. Arenal (fiel á ortodoxia dun capitalismo ortodoxo) reduce o papel do Estado, que debe respectar sen se inmiscir máis que nos casos extremos o xogo e a dialéctica das clases sociais, porque «lo que hay que desear es que el Estado haga lo menos posible de aquello que es preciso hacer y que, sin su intervención, se hace bien; lo que hay que temer es que lo que es necesario no lo haga nadie, o lo haga quien lo hace peor» ${ }^{19}$.

Cando se integra na Institución Libre de Enseñanza, sen abandonar as tarefas caritativas e a súa entrega en favor da redención dos presos, parece que se lle agu-

19 Arenal, Concepción (1997): «La instrucción del pueblo. Memoria premiada por la Real Academia de Ciencias Morales y Políticas en el concurso de 1878», en Celia Pereira Porto, op. cit., p. 102. 
diza o senso crítico sobre as persoas e institucións insensibles á dor dos vencidos e castigados.

É nese momento cando elabora o seu traballo sobre Feijoo, referente para ela do que debe e non debe ser unha mente privilexiada. Por iso a súa análise do comportamento do monxe bieito merécelle aprobacións e reprobacións porque, sendo un faro que ilumina o seu tempo histórico, non só proxecta luz senón tamén sombras e tebras.

A autora comprométese a non se deixar seducir por «fanatismo de partido ni de escuela» e lembra que «nuestro espíritu, animado por el deseo de la justicia, puede elevarse a esas serenas regiones donde se comprende y se hace» ${ }^{20}$. Malia estudar a Feijoo «imparcialmente, sin idea preconcebida; si hemos tomado nota de sus aciertos como de sus errores; si el amor a la verdad que a él guiaba nos ha guiado», non estaba segura de acertar no retrato e na valoración de Feijoo ${ }^{21}$.

\section{Feijoo, filósofo}

Si de filósofo se califica a un hombre cuya razón es capaz de elevarse a metafísicas abstracciones y profundizar en el estudio de la naturaleza humana, observador analítico, lógico, dispuesto a pedir a la duda sus motivos y a la afirmación sus pruebas [...] era un filósofo Feijoo ${ }^{22}$.

Pero se por filósofo se entende levar a investigación e a análise ata os últimos confíns, que conceptos como Deus, natureza e humanidade estean tamén sometidos ao raciocinio, entón Feijoo non foi filósofo porque a maior parte destas cuestións as recibiu resoltas pola autoridade da Igrexa, á que en todo caso se somete. Ten que «retraerse de tratar cuestiones fundamentales en las que el círculo de lo opinable era cada vez más reducido» ${ }^{23}$.

Insatisfeito coas distintas escolas filosóficas, «ciudadano libre de la república literaria, ni esclavo de Aristóteles ni aliado de sus enemigos, escucharé siempre, con preferencia a toda autoridad privada, lo que me dicten la experiencia

\footnotetext{
20 Arenal, Concepción (1877): «Juicio crítico de las obras de Feijoo», Revista de España, LV, 111.

${ }^{21}$ Ibidem.

22 Idem, 187.

${ }^{23}$ Ibidem, onde se recolle o texto de Feijoo.
} 
y la razón» ${ }^{24}$ e empregando unha imaxe metafórica, exculpatoria da súa indecisión, «mientras el mar no se aquieta, es prudente detenerse a la orilla; quiero decir, mientras no se descubre rumbo, libre de grandes dificultades para engolfarse dentro de la naturaleza, dicta la razón mantenerse en la playa, sobre la arena seca de la Metafísica» amparado neste punto pola "Iglesia universal, la cual es cierto que no puede errar en materias de fe, no por imposibilidad antecedente que se siga a la naturaleza de las cosas, sino por la promesa que Cristo la hizo de su continua asistencia y de la del Espíritu Santo en Ella» ${ }^{25}$. Por conseguinte, escribe C. Arenal, «el origen de todo conocimiento debe ser el estudio, la observación, la experiencia, no admitiendo contra ellos autoridad privada, pero sometiéndose incondicionalmente a la de la Iglesia».

Pronúnciase Feijoo con evidente desdén contra os filósofos da antigüidade, nos que nada ve aproveitable (Demócrito, Epicuro, Zenón, Pitágoras, etc.). Escribe:

Todos estos siglos se perdieron para la filosofía, y toda la ocupación de los filósofos que florecieron en ellos se puede decir que fue una mera ociosidad, pues no hicieron otra cosa que tomar sueños por realidades, sombras por luces, ilusiones por aciertos, parelias por soles. Si lo que dieron a especulaciones vagas dieran a observaciones experimentales, ¡oh! que gazofilacio de física hubieran dejado a la posteridad, en vez de los inútiles harapos que hemos heredado de ellos! ${ }^{26}$

Tivo Feijoo a oportunidade de redactar un curso completo de Filosofía, que lles impartiu aos seus alumnos do colexio dos bieitos de Lérez (Pontevedra) durante os cursos comprendidos entre 1704 a 1707 (Lóxica, Metafísica, Filosofía Natural e Psicoloxía). Dado o sistema empregado entón nas clases, nas que o profesor ditaba o texto, temos a garantía de que o Curso recollido polo alumno

${ }^{24}$ Idem, 188.

25 Ibidem, onde se recolle o texto de Feijoo.

${ }^{26}$ Idem, 190. As "parelias» eran unha especie de meteoritos ou soles aparentes (Diccionario de la lengua castellana compuesto por la Real Academia Española, reducido á un tomo para su mas fácil uso [Madrid, 1780, 690]). 
frei Matías de la Vega, conservado e publicado por R. López Vázquez ${ }^{27}$, contén ipsissima verba o texto ditado por Feijoo.

Aínda que López Vázquez destaca a «brevidade, claridade, coherencia, síntese, incluso beleza, sinxeleza e profundidade» do texto, en realidade nada hai nel que non atopemos noutros cursos que coñecemos, sempre a través de alumnos, contemporáneos ou posteriores. O curso de Feijoo sométese á ratio docendi da orde beneditina e nel non se atopa o resplandor dunha xenialidade ou dunha posición arriscada. Pura vulgaridade escolástica.

Conclúe C. Arenal dicindo que Feijoo «tuvo facultades para ser un filósofo, pero que no ha podido hacer más que manifestar disposiciones y tendencias filosóficas» ${ }^{28}$.

\section{Teólogo e moralista}

Con moita chanza dinos Feijoo que decidiu non escribir tratados de Teoloxía porque «¿Que puedo yo adelantar en asuntos que con tanta reflexión meditaron hombres insignes?». Só conseguiría, engade, amontoar nos faios de tres ou catro celas os centos de libros non vendidos. Por utilidade, pois, negouse sempre a escribir libros de Teoloxía.

Pero, como destaca Concepción Arenal, esta decisión ten outras motivacións: non ten que someterse aos catro cadeados ou censuras: a da Orde, a do bispo ordinario, a do Rei e a da Inquisición; catro cadeas que facían desistir o ánimo máis temperado.

Se non escribiu grosos tratados teolóxicos, derramouse, en troques, en consellos e en críticas sobre o uso improcedente da relixiosidade. En ton distendido, irónico e, ás veces, cotifeiro, sorprendíase da eficacia de Nosa Señora de Nieva, que inmunizaba os seus fieis contra as tempestades e, sobre todo, contra os raios. A venda de estampas, medallas e o rito contaxioso de tocar cun pano a imaxe eran un «milagroso preservativo para cualquiera que con religiosa veneración la lleva consigo».

\footnotetext{
27 López Vázquez, Ramón (1995): O Padre Feixoo, escolástico, Santiago de Compostela, Centro de Investigacións Lingüísticas e Literarias Ramón Piñeiro, Xunta de Galicia.

28 Arenal, Concepción (1877): «Juicio crítico de las obras de Feijoo», Revista de España, LV, 202.
} 
Da mesma maneira ironiza sobre as flores de San Luis do Monte (Asturias), flores milagrosas que resultou que nin eran milagres nin sequera flores...

Tamén atacou a práctica dos exorcismos, cuxa falsidade el mesmo puido comprobar cando ante unha suposta posuída «empecé mis conjuros con versos de Virgilio, de Ovidio, de Claudiano y de otros poetas [...]. Singularmente al empujarle la pomposa introducción de la Farsalia de Lucano [...], casi llegué a temer que de veras se espiritaba», logo acercoulle unha chave dun escritorio, coma se fose unha reliquia, e creceron os seus espasmos "como quien está bien ejercitada en este juego. En fin, sobradamente enterado del embuste de esta mujercilla, la despedí».

Esta liberdade de espírito, esta valentía desaparecía cando as súas opinións rozaban non a ortodoxia senón o poder coactivo da Igrexa. No seu discurso «Música de los templos» bramaba contra a utilización dos violíns dentro das igrexas, pero bastou que Benedicto XIV os permitise para que «retractara gustoso lo que escribí sobre este punto». Convencido da cientificidade do sistema copernicano, renegou del por ser oposto á Sagrada Escritura. Por iso non estraña a defensa da permanencia da Inquisición e non só en España senón en todo o mundo, porque o sucedido noutros lugares «nos da a conocer la necesidad que hay en otros reinos de erigir para semejantes causas el rectísimo tribunal de la Inquisición, que acá, por gran dicha nuestra, tenemos» ${ }^{29}$.

Por todo isto Concepción Arenal conclúe que «Feijoo compró la paz a costa de la lógica; que su espíritu contuvo los ímpetus de independencia; que se sometió todo entero; que el religioso triunfó del pensador, prefiriendo la inmolación a la rebeldía ${ }^{30}$.

\section{Feijoo, xurista e canonista ${ }^{31}$}

Dúas son as cuestións que reclaman a preferente atención de Concepción Arenal: a xustiza, e máis en concreto a xustiza no ámbito penal, e o xuízo sobre o poder absoluto dos reis.

29 Arenal, Concepción (1877): «Juicio crítico de las obras de Feijoo», Revista de España, LV, 209.

30 Idem, 213.

31 É imprescindible reler as afirmacións de Feijoo sobre a xustiza tendo en conta a magnífica monografía do profesor Luis Rodríguez Ennes El padre Feijoo y el derecho de su tiempo: una visión premonitoria de problemas candentes en la actualidad, Vigo, Consello Social da Universidade, 2013. 
Recoñece Concepción Arenal que bastaría a publicación do estudo de Feijoo Balanza de Astrea para consideralo un intelectual de criterio recto. Porén, hai aspectos en que a sensibilidade humanista do bieito non sempre se sostén. Tal é o caso da tortura xudicial, da pena de morte, etc. Referíndonos aos dous temas centrais: o da tortura como proba xudicial e a pena de morte, o pensamento de Feijoo é bastante confuso e, mesmo, parece contraditorio.

Feijoo pronúnciase contra a tortura porque case sempre resultaba ineficaz como medio de proba xudicial, pero non dita unha sentenza reprobatoria dende a ética contra a tortura en canto tal, como si fai o P. Sarmiento ${ }^{32}$; debendo deducir que, no suposto de que a tortura fose un instrumento eficaz para o descubrimento do crime, o seu uso sería lexítimo.

Polo que respecta á pena de morte, sen ser un defensor per se, entendía que a súa aplicación precavía e, por conseguinte, impedía moitos outros crimes ${ }^{33}$.

Para C. Arenal estes posicionamentos revelan que Feijoo non tiña unha noción exacta da xustiza en materia criminal, porque, aínda que teoricamente defende a dobre finalidade da pena (resarcimento da xustiza obxectiva e corrección do delincuente), na práctica Feijoo esquece a segunda finalidade, especialmente nos delitos de maior transcendencia pública. Por iso defende que nos crimes de herexía ou de lesa maxestade o restablecemento da xustiza obxectiva era tan urxente que o xuízo debería dilixenciarse con toda rapidez, «aun a riesgo de que sea condenado un inocente». Do que conclúe Arenal que Feijoo, nestes casos, «no veía más que el derecho de la sociedad, el del reo desaparecería muchas veces en teoría y, con mayor frecuencia, en la práctica» ${ }^{34}$.

Defende Feijoo un caso no dereito penal canónico tan inhumano que pon de manifesto o servilismo das mentes máis lúcidas na Igrexa. A causa dunha «Constitución do Papa Pío V» (1566), ordenábase que, se os médicos advertían no enfermo síntomas de gravidade e a posibilidade de morrer, se o enfermo non solicitaba confesión, o médico ipso facto debía deixalo sen atención ningunha, ameazándoo en caso contrario coa pena de excomunón e de denuncia ante o colexio médico para que expulsasen o doutor, impedíndolle o exercicio da medi-

32 Rodríguez Ennes, Luis (2013): El padre Feijoo y el derecho de su tiempo: una visión premonitoria de problemas candentes en la actualidad, Consello Social da Universidade de Vigo e Dykinson, 62-65.

33 Idem, 69.

34 Arenal, Concepción (1877): «Juicio crítico de las obras de Feijoo», Revista de España, LV, 401. 
cina. Esta Constitución tan cruel e inhumana aínda se mantén na reedición das Constitucións Sinodais de Ourense do ano 1843 (Lib. V, tít. VI, const. 4, 273-274).

Feijoo escribe ao respecto: «Lo que en ella pretende el Santo Legislador [refírese a Pío V] no es que el médico abandone al enfermo [...] sino cuando los rehusa [os sacramentos] con negligencia o repugnancia voluntaria y libre». E isto faise "porque el miedo de que le falte la medicina del cuerpo le reduzca a implorar la del alma ${ }^{35}$. Escusa que non pode borrar a nota de inhumanidade de tal censura.

Polo que atinxe á estrutura do poder político, moitos comentaristas déixanse engaiolar por expresións como que os reis son criaturas idénticas coma as demais, pero esquecen que o pai bieito nunca rexeitou a monarquía absoluta, nin a orixe divina do poder monárquico, nin o dereito hereditario como fórmula de transmisión deste absoluto poder. Tampouco alude nunca ao dereito de insubordinación, nin ao tiranicidio, polo menos como o contempla Santo Tomás ${ }^{36}$. Limitacións que Concepción Arenal explica empregando a máxima do propio Feijoo «No es lo que se siente lo que se dice, cuando es delito decir lo que se siente».

\section{Feijoo e a valoración das mulleres}

No seu discurso Defensa de las mujeres é consciente do grave empeño en que se poñía porque «defender a todas las mujeres viene a ser lo mismo que ofender a casi todos los hombres, pues raro hay que no se interese en la precedencia de su sexo con desestimación del otro». E tanto repetiron os homes «que las mujeres son de cortísimo alcance, que a muchas, si no a las mas, ya se lo han hecho creer».

Para probar la igualdad de las almas en los dos sexos, y si no la identidad, la equivalencia de facultades, nuestro autor combate en todos los terrenos y echa mano de la anatomía, de la fisiología, de la historia, de la lógica y con argumentos concluyentes combate a tantos autores que con Aristóteles a la cabeza, han considerado a la mujer no solo como inferior al hombre sino como un animal imperfecto ${ }^{37}$.

35 Idem, 209.

36 Idem, 407.

37 Idem, 194-195. 
Porén, a defensa filosófica da igualdade da muller con respecto ao home non implicaba a asunción da igualdade de dereitos por parte de Feijoo ou, polo menos, non consta na súa obra ${ }^{38}$. Moito máis avanzado neste punto era Sarmiento cando definía que a diferenza entre homes e mulleres non era de natureza senón de educación.

Recoñecendo todo isto, Concepción Arenal critica duramente a Epístola de Feijoo a unha moza que lle pregunta se pensa que é mellor o estado de casada ou a profesión relixiosa. Ante a resposta do pai bieito en favor do convento, rebélase a escritora ferrolá porque no fondo Feijoo lle está a recomendar «la comodidad, el ocio y el sosiego» apartándoa da loita cotiá. Non pode ser considerado «estado perfecto el de una criatura que no ama, ni piensa, ni trabaja», que así pode definirse «a una monja de vida contemplativa». Máis aínda, chamarlles ás mulleres que optan polo convento «esposas de Cristo» non deixa de ser «una ficción medio ridícula, medio impía». En troques, valora as monxas activas, comprometidas coa sociedade e moi en especial as Fillas ou Monxas da Caridade ${ }^{39}$.

\section{Recapitulación final}

A fisionomía moral de Feijoo era «bella, noble, imponente» pero asume todas as contradicións do seu tempo histórico. O espírito innovador e aparentemente revolucionario aparece sempre coutado, controlado polos poderes dunha sociedade moi atenta a mobilizar os mecanismos de persecución cando intuían que determinadas ideas podían danar a estrutura ideolóxica dun sistema creado para soster a alianza entre o Trono e o Altar, que era toda a base dunha sociedade en que os distintos roles estaban perfectamente distribuídos.

Xa se comprende que un traballo destinado a glorificar a Feijoo non podía facer esta crítica. Por iso o xurado de Ourense o aprobou, non así o da Universidad de Oviedo, que ditaminou que quedase «unánimemente excluido» pola «marcada tendencia que el autor revela en el curso del erudito trabajo a hacer partícipe de sus racionalistas ideas al ilustre monje, interpretando de una manera violenta el espíritu de sus inmortales obras en algunos de los pasajes que cita».

38 Rodríguez Ennes, Luis (2013), op. cit., 199-200.

39 Arenal, Concepción (1877): "Juicio crítico de las obras de Feijoo», Revista de España, LV, 222. 


\section{PARDO BAZÁN E FEIJOO}

Interesa moito coñecer as súas fidelidades ideolóxicas básicas e a súa militancia para poder interpretar axeitadamente a versión que nos ofrece da obra do P. Feijoo.

Cando escribe esta obra militaba no carlismo, ao que lle prestara apoio económico e propagandístico, aínda que a súa intelixencia e sensibilidade lle impedían asumir certos obxectivos como o da recuperación da Inquisición.

Aínda que a partir de 1888 e como consecuencia da postura hostil do sector carlista de Nocedal fai unha intelixente retirada das posturas máis radicais, podemos asegurar que nunca renunciou a unha silenciosa militancia en favor da Causa $^{40}$.

De como puido conciliar esta militancia e, ao mesmo tempo, gozar da estima e amizade dos homes de prol da Institución é algo que ignoramos e preferimos non aventurar hipóteses.

Cando só tiña 26 anos escribiu uns apuntamentos titulados «Teoría del Absolutismo», que demos a coñecer hai algún tempo ${ }^{41}$. Estamos diante da primeira redacción para un traballo máis amplo e que afortunadamente non chegou a concluír nin a publicar porque a obra, tal e como a concibía, superaba en moito a súa capacidade, aínda recoñecéndolle a dona Emilia todo o seu moito saber.

Seguindo a pegada do tradicionalismo francés, especialmente a De Bonald, ao que sorprendentemente nunca cita, dá por suposto que a sociedade está sometida a unhas leis marcadas ab initio polo creador polas que deben rexerse os Estados. Deus elixiu a monarquía como a forma de goberno das sociedades, pero afastada do despotismo e limitada por disposición divina polos dereitos da persoa, así mesmo fixados por Deus, e pola convivencia harmónica con outras institucións, como a Igrexa, que garantía a ortodoxia do proxecto de goberno da monarquía absoluta.

40 Barreiro Fernández, Xosé Ramón / Patricia Carballal Miñán (2007): «Emilia Pardo Bazán y el debate entre "La Fe" y "El siglo futuro"», en Xosé Manuel González Herrán, Cristina Patiño Eirín e Ermitas Penas Varela (eds.), Emilia Pardo Bazán, el periodismo. Actas del III Simposio, A Coruña, Real Academia Galega / Fundación Caixa Galicia, 131-151.

${ }^{41}$ Barreiro Fernández, Xosé Ramón (2005): «A ideoloxía política de Emilia Pardo Bazán», La Tribuna. Cadernos de Estudios da Casa-Museo Emilia Pardo Bazán, 3, 39-69. 
Por conseguinte, a chamada soberanía nacional e a súa capacidade para estruturar a convivencia política deben ser consideradas unha corrupción do plan divino e as limitacións impostas á Igrexa a través do laicismo son outros atentados da sociedade civil contra o plan divino.

O absolutismo non é, por conseguinte, a ditadura nin a tiranía. É un sistema que funcionou con eficacia durante centos de anos, porque a propia lei divina se encargou de poñer límites a este poder.

Se mesturamos esta ideoloxía coa súa militancia carlista, despréndese un pensamento radicalmente oposto ás conquistas do liberalismo dende a Revolución Francesa e a constitución dos Estados Unidos de América, é dicir, un pensamento involucionista que non tiña aplicación xa en ningún dos países máis avanzados.

Iso explica a fácil adaptación de dona Emilia ao tradicionalismo e como a súa achega foi positivamente valorada, agás a aproximación ao naturalismo e, sobre todo, a amizade cos innovadores da Institución Libre de Enseñanza, que tan frutífera lle foi de cara á crítica.

No ano 1874 Pardo Bazán descobre a Feijoo ${ }^{42}$ e queda seducida. E o «cíclope» capaz de erguer sobre as súas costas a modernización do país é un «Proteo científico», un home «omnisciente que no deja rincón que no registrase». Del arranca a modernidade da vida científica de España. É, en fin, o primeiro crítico do que se pode gabar España e ata hoxe (escribe isto en 1876) non foi igualado ${ }^{43}$.

Ao igual que no ano 1882 Menéndez Pelayo relativizara non pouco os méritos de Feijoo ${ }^{44}$, Pardo Bazán, no discurso pronunciado en Ourense no ano 1887, maniféstase máis comedidamente, pero mantén a tese central de que na escurida-

42 Pardo Bazán, Emilia (1877): «Estudio crítico de las obras de Feijoo por la Señora Doña Emilia Pardo Bazán», en Certamen Literario en conmemoración del Segundo Centenario del Nacimiento de Fray Benito Jeronimo Feijoo, autor del Teatro Crítico Universal, celebrado en Orense el 8 de octubre de 1876: obras premiadas, Madrid, Tipografía y estereotipia Perojo, 161-162.

43 Barreiro Fernández, Xosé Ramón (2003): «O Estudio Crítico das obras do P: Feijoo de Pardo Bazán, Concepción Arenal e Miguel Morayta. O certame de 1876», La Tribuna. Cadernos de Estudios da Casa Museo Emilia Pardo Bazán, 1, 80.

44 Menéndez Pelayo acusa os críticos de descoñecer a cultura do século XVII por enaltecer excesivamente o P. Feijoo. Vid. Historia de los Heterodoxos, Madrid, Imprenta de F. Maroto e hijos, 67-90. 
de da cultura ibérica «puede asegurarse que la noche de la decadencia se ilumina con resplandor de aurora $»^{45}$.

\section{Feijoo como filósofo}

Como no seu día escribiu Ardao ${ }^{46}$, pretender expoñer o pensamento de Feijoo nun esquema sistemático, captando a súa articulación lóxica, é unha empresa imposible. Non obstante, quedan refachos luminosos que preanuncian a posibilidade dun corpus en que, utilizando o método empírico, podería aproximarse a unha filosofía da ciencia. Pero incluso no aspecto científico carece da coherencia suficiente que responde a un sistema. Coñece as teorías de Newton, pero non as segue porque, segundo a benévola interpretación de Pardo Bazán, refusaba integrarse nunha escola para poder seguir sendo independente. Asume o escepticismo pero non como un sistema para aproximarse á ciencia, senón como unha especie de reserva do seu xuízo que protexe a súa liberdade para se inclinar en cada caso polas opcións que máis o convencesen.

O que valora Pardo Bazán moi positivamente é a ortodoxia de Feijoo: «No contienen los escritos de Feijoo proposición que, recta y caritativamente interpretada, lastime en lo más mínimo la integridad del dogma» e levando as augas ao seu rego engade: «Feijoo es la prueba clara de la amplitud que otorga al pensamiento el catolicismo y del vasto campo que deja en las materias opinables $»^{47}$.

\section{Feijoo literato}

Sorprende o escaso espazo que se lle dedica a Feijoo nas historias da literatura española cando Azorín non dubidou en cualificalo como «generador de la prosa moderna».

\footnotetext{
45 Discurso de 1887, en De mi tierra (1888), A Coruña, Tipografía de La Casa de Misericordia, 153). Na disertación, Pardo Bazán recolle as críticas formuladas por Menéndez Pelayo, pero no canto de as refutar pediu un aplauso ao público asistente en honor de D. Marcelino, que, por suposto, o público non negou. Evitou desta forma que se molestase Menéndez Pelayo, evitando os dardos da súa crítica.

46 Ardao, Arturo (1962): La filosofía polémica de Feijoo, Bos Aires, Losada.

47 Pardo Bazán, Emilia (1888): De mi tierra, A Coruña, Tipografía de la Casa de Misericordia, 175.
} 
Pardo Bazán tampouco manifesta entusiasmo pola súa prosa, destacando os «largos y fastidiosos párrafos [...] galicismos y escolasticismos que desfiguran y afean extrañamente el conjunto» ${ }^{48}$, pero procurou explicar o seu estilo descoidado polo seu afán de acercarse ao gran público e porque preferiu sempre a orixinalidade evitando seguir os modelos literarios do seu tempo.

Feijoo empregou un discurso "gacetal» (propio das gazetas populares) para popularizar máis o seu discurso, procurando «facilidad y provecho». Por iso, podemos asegurar que gran parte do éxito de Feijoo se debeu a adoptar $o$ ensaio como medio de comunicación ${ }^{49}$, entendendo por ensaio unha composición breve sobre temas de actualidade, sen pretensións de exhaustividade, sen someterse aos canons formais de multiplicar as citas e aparentemente carecendo dunha estrutura determinada ${ }^{50}$. Foi, pois, o primeiro gran ensaísta en España.

No discurso de 1887, Pardo Bazán mantén as mesmas ideas. O estilo literario de Feijoo explícao el mesmo cando di que a forma de escribir «se me vino, tal como lo veis, no lo busqué yo», é dicir, é un produto da natureza e non da arte ou do artificio.

Grazas a este estilo, Feijoo foi o autor máis lido no seu tempo, mentres que os escritos do P. Isla, «más correcto» no seu estilo, apenas se len no presente.

48 Pardo Bazán, Emilia (1877): «Estudio crítico de las obras de Feijoo por la Señora Doña Emilia Pardo Bazán", en Certamen Literario en conmemoración del Segundo Centenario del Nacimiento de Fray Benito Jeronimo Feijoo, autor del Teatro Crítico Universal, celebrado en Orense el 8 de octubre de 1876: obras premiadas, Madrid, Tipografía y estereotipia Perojo, 25.

49 Álvarez Barrientos, J. (1995): «El ensayo del siglo XVIII», en V. García de la Concha (dir.), Historia de la Literatura Española, I, Madrid, Espasa-Calpe, 61-68.

50 Gómez Martínez, J. L., Teoría del ensayo, Salamanca, Universidad, 1981. O profesor e vello amigo Mestre Sánchez axuíza a Feijoo nun ton brusco que, as veces, usa: «Feijoo es el creador del ensayo, mérito suyo indiscutible, en el que es dueño absoluto y luce sus cualidades de perspicacia, gracia e ingenio en un género en la medida de su capacidad. Para ello, Feijoo necesita hablar de omini se scibile de filosofía sin especiales conocimientos metafísicos, de derecho sin ser jurista, de historia sin haber pisado un archivo ni haber manejado documento original alguno, de medicina sin haber observado a un enfermo... Es la cruz del ensayista...» (Mestre, A. [1976]: Despotismo e Ilustración en España, Barcelona, Ariel, 29). 


\section{Feijoo moralizador e moralista}

Distingue Pardo Bazán en Feijoo dúas cuestións: a loita do pai bieito contra a superstición e os falsos saberes e o que poderiamos entender por doutrina positiva sobre a moral, unha especie de "metafísica de los hábitos sociales»"1.

Feijoo dedicou boa parte dos seus escritos a denunciar as supersticións e as necidades espalladas como verdades entre a intelectualidade. Polo seu «desinteresado culto a la verdad», librou duras batallas contra todos aqueles, sen excluírmos as ordes relixiosas, que se beneficiaban da superstición popular.

Xa como moralista, procurou humanizar os ditados da lei moral aconsellando modelos de vida máis acordes coa vida do pobo. Por iso refuga do pietismo que na práctica se convertía nunha especie de cerimonialismo (misas, procesións, triduos, novenas, etc.), que desviaban a atención preferente dos cristiáns, que debían concentrarse nos oficios e responsabilidades de traballo, e non no culto ou relixión.

Pardo Bazán compara, por exemplo, a moral matrimonial aparecida en La perfecta casada, de frei Luis de León, coas normas que con respecto ao matrimonio dá Feijoo e conclúe que na obra de frei Luis dificilmente se atopará un modelo válido para o século XVIII.

No seu traballo sobre La urbanidad, Feijoo procura a simplicidade, a sensatez e a racionalidade: «El echar en olvido la felicitación de un día de cumpleaños era suficiente motivo para que se indispusiesen las familias [...] en que un viaje de veinticuatro horas exigía una despedida general y en que en los saraos se estaba como en un entierro ${ }^{52}$ eran algunhas das situacións que Feijoo criticaba para que as relacións sociais fosen sempre máis humanas.

\footnotetext{
51 Pardo Bazán, Emilia (1877):, «Estudio crítico de las obras de Feijoo por la Señora Doña Emilia Pardo Bazán», en Certamen Literario en conmemoración del Segundo Centenario del Nacimiento de Fray Benito Jeronimo Feijoo, autor del Teatro Crítico Universal, celebrado en Orense el 8 de octubre de 1876: obras premiadas, Madrid, Tipografía y estereotipia Perojo, 60 e ss.

52 Idem, 67-68.
} 


\section{Feijoo e as cuestións xurídico-políticas}

Non interpretou acertadamente Pardo Bazán a postura de Feijoo sobre a proba xurídica do tormento. Como xa expuxemos, Feijoo entendía que era ineficaz na maior parte dos casos, pero reservábaa para aqueles delitos gravísimos que debían ser condenados de inmediato polas repercusións sociais.

Engade que a pena de morte «túvola por indispensable pilar para el mantenimiento del orden social» ${ }^{53}$.

«No puede negarse —escribe Pardo Bazán— en manera alguna que en Feijoo hay un crítico y un reformador, pensar otra cosa sería desconocerlo. Pero fuera también no comprenderle, o comprenderle mal, el imaginar que a todo lo que tiene de reformador y de crítico se agrega ni un átomo de revolucionario» e comparando a Feijoo cos enciclopedistas que non dubidan en «improvisar» institucións e leis de acordo coa «efervescencia de la opinión» apláudeo por non dedicar nin un parágrafo a atacar a organización social de España, e por iso «en todos sus escritos se advierte una completa y sincera adhesión a los poderes soberanos de su patria» ${ }^{54}$.

Está claro que Pardo Bazán reutilizando a Feijoo está defendendo un modelo de sociedade de tipo absolutista. Separa para iso dous conceptos: interpretar o mundo e cambialo. Probablemente, tal xuízo non sería aceptado polo propio Feijoo, quen criticou con fereza os malos costumes, as supersticións e a falsa ciencia para construír un país novo. Certo é que foi respectuoso cos principios básicos daquela sociedade, mais non porque se compracese neles, senón por imposibilidade de derruílos.

\section{Conclusión}

Pardo Bazán glorifica a Feijoo malia recoñecer as limitacións en cuestións puntuais. Destacou a súa modernidade científica e valoraba a súa coraxe para extirpar as supersticións e falsos saberes, pero sobre todo que compatibilizase esta

\footnotetext{
53 Idem, 122.
}

54 Idem, 126. 
modernidade co maxisterio da Igrexa. Pardo Bazán fixo unha hábil glorificación de Feijoo envolta nun fermoso estilo literario.

O texto que presentou dona Emilia ao premio revela descoñecemento da cultura española dos séculos XVII e XVIII, elude habilmente as cuestións máis polémicas de tipo teolóxico, xurídico e histórico, e hai un excesivo tratamento parafrástico dos textos de Feijoo (defecto en que coincide con C. Arenal) sen dúbida para poder presentar un texto que ocupa 148 páxinas impresas.

De todo isto era consciente Pardo Bazán, que, nunha carta a Menéndez Pelayo ${ }^{55}$, lle recoñece que o seu libro era «tan defectuoso y malo que hasta reeditarlo corrigiéndolo no me atrevo en modo alguno a mandárselo».

Non nos consta que fixese tales correccións e así quedou o libro para sempre. «Este librucho que la Comisión de Orense, por fortuna mía, archivó y no puso a venta ${ }^{56}$, engade Pardo Bazán.

\section{RECAPITULACIÓN FINAL}

No ano 1877, con motivo do certame de Ourense asistimos a un anticipo da loita que se está fraguando e que se coñecerá como o debate sobre a Ciencia Española. As dúas intelectuais galegas (as dúas tiñan informadores en Ourense que probablemente eran sabedores da intención de se presentaren ambas e así llelo comunicarían ás súas protexidas) eran conscientes de que os seus estudos sobre Feijoo representarían dous modelos antagónicos xa que respondían a dúas interpretacións non coincidentes e, incluso, contrarias sobre a ciencia en España.

Por que o P. Feijoo? Por que motivos se concentra nel a contradición? Indubidablemente porque o P. Feijoo fora o escritor máis famoso de España no seu tempo, o máis xenial e independente, a proa da modernidade. Prestara atención a todos os temas que dunha ou doutra maneira lles interesaban aos intelectuais e ás clases

55 Carta do 26-IX-1879, en Ana María Freire López, «Feijoo en el siglo XIX: Concepción Arenal, Emilia Pardo Bazán y Marcelino Menéndez Pelayo», en José Checa Beltrán / Joaquín Álvarez Barrientos (coords.), El siglo que llaman ilustrado. Homenaje a Francisco Aguilar Piñal, 1996, 372.

56 Anos despois, alguén liberou este fondo de libros na Deputación de Ourense e circularon polo mercado do libro antigo. 
medias: as novas teorías científicas ${ }^{57}$ que circulaban por Europa, as artes, a música, as supersticións, os fenómenos da natureza, o matrimonio, a urbanidade como fórmula de convivencia social, etc.

Ademais porque Feijoo foi capaz de crear novos mecanismos de comunicación social, especialmente o ensaio, que facía moi atraente a súa lectura. Finalmente, porque utilizaba ás veces en forma destemida e valente a crítica social, cunha prosa irónica e algunha vez sarcástica, que rachaba con todos os moldes literarios que o precederan.

A partir da mesma obra aparecen dous discursos interpretativos de Concepción Arenal e Emilia Pardo Bazán que, sen forzar excesivamente a literalidade da obra do bieito galego, chegan a conclusións moi diferentes, o que revela as predeterminacións ideolóxicas de cada unha delas pero tamén a estudada neutralidade de Feijoo nos temas máis delicados.

Para C. Arenal o P. Feijoo era o xenio que podería cambiar o rumbo da ciencia española asumindo e propagando as teorías científicas de Newton, criticando a alianza do Altar e do Trono ou a estrutura do poder político que esmagaba calquera intento de independencia científica, é dicir, convertendo o movemento ilustrado nun verdadeiro Século das Luces, como sucedeu en moitos países de Europa, protagonizando, en definitiva, a revolución intelectual de Francia que desembocou na revolución política. Pero Feijoo optou por someterse aos poderes, producindo un movemento ilustrado que non rematou na revolución senón no Despotismo Ilustrado.

En troques, para E. Pardo Bazán Feijoo representa o máximo exemplo de fidelidade á nosa tradición intelectual. Puido ser o Voltaire español do século XVIII pero nel puido máis a fidelidade á tradición, é dicir, á Igrexa e ao poder absoluto do monarca que a ilusión de liderar un movemento que rompese a harmonía social que se vivía en España. Feijoo demostra, ademais, a falsidade do principio de que a ciencia en España non evolucionou como consecuencia dos atrancos que impuxo a Inquisición.

Velaí as dúas lecturas contrarias que fan estas dúas intelectuais galegas da obra do P. Feijoo.

57 Aínda que Marañón di, con admiración, que Feijoo dispuxo dun microscopio «tal vez el primero que vino a España», debemos situar esta afirmación entre as lendas que arrodearon a Feijoo. No ano 1687 publicouse en Valencia a obra de J. B. Corachan Methodus elaborandi componendique telescopia et microscopia, con gravados sobre diferentes tipos de microscopios. 
PRESENZA DO PADRE FEIJOO EN GALICIA

Francisco Díaz-Fierros Viqueira Universidade de Santiago de Compostela 



\section{INTRODUCIÓN}

Os estudos relativos a Feijoo e Galicia refírense, fundamentalmente, á presenza de Galicia ou dos temas galegos na súa obra. Este sería o caso da conferencia Galicia en el Padre Feijoo ${ }^{1}$, logo impresa, ou o artigo "Galicia y el Padre Fejoo» ${ }^{2}$. Ambos os dous teñen idénticos obxectivos, aínda que o primeiro ten un carácter máis enfático e xeral, introducindo frecuentes comentarios sobre o estilo e o talante do Padre Mestre. No segundo detéctase un enfoque máis sistemático e concreto.

Outra temática, tratada cunha certa amplitude nos estudos de escritores galegos sobre Feijoo, é a "galeguidade», que, segundo Blanco-Amor ${ }^{3}$, reviste unha especial dificultade pois «lo gallego del Padre Maestro es precisamente lo que se escurre por entre las mallas generalizadoras, lo que se salva de la voluntad que propone en el temperamento que dispone». Inaugurou esta temática Manuel Murguía cos seus traballos sobre galegos ilustres ${ }^{4}$ e despois foi continuada, entre outros, por Pardo Bazán, Martínez-Risco, Marañón, Filgueira Valverde, Vilanova, Núñez Búa, etc.

A formulación simétrica destes estudos, noutras palabras, a análise de como foi acollida a obra de Feijoo en Galicia, practicamente non foi considerada, agás en pequenos apuntamentos de Otero Pedrayo na súa monumental obra El Padre Feijoo. Su vida, doctrina e influencias ${ }^{5}$ e doutros autores en traballos concibidos con diferentes obxectivos. A razón pode estar na complicación dos estudos diacrónicos, que abranguen amplos períodos de tempo (neste caso desde o século XVIII ata $\mathrm{O} X \mathrm{XI}$ ), e tamén na tendencia dos historiadores profesionais a se centrar, normalmente, en períodos temporais moito máis concretos por cuestións de rigor científico.

De todas as maneiras, non deixan de ter interese estas esculcas relativas á análise da evolución dun proceso nunha ampla franxa cronolóxica que neste caso sería

1 Montero Díaz, Santiago (1931): Galicia en el Padre Feijoo (Conferencia), Madrid, Imp. La Rafa.

2 Martínez Lois, Andrés (1988): «Galicia y el Padre Feijoo», Revista / Instituto José Cornide de Estudios Coruñeses, A Coruña, 24, 117-147.

3 Blanco-Amor, Eduardo (1966): El Padre Feijoo. Tema con variaciones, Vigo, Ed. Galicia.

4 Murguía, Manuel (1876): «Fr. Benito Jerónimo Feijóo», Boletín de la Real Academia Gallega, tomo 32:358, 5-27.

5 Otero Pedrayo, Ramón (1972): El Padre Feijoo. Su vida, doctrina e influencias, Ourense, Instituto de Estudios Orensanos Padre Feijoo. 
a recepción da obra e o pensamento do Padre Feijoo en Galicia. Con elas, pódese ter unha ollada máis rica e pormenorizada de cales poden ser as claves das respostas dunha sociedade concreta diante de incentivos intelectuais. Por outra parte, pode observarse como cun mesmo obxectivo as interpretacións poden ir variando e modulándose na historia dunha comunidade segundo os criterios e valores vertebradores dunha determinada época. As dificultades destas investigacións son evidentes, pois cada época ten as súas fontes particulares de coñecemento cuns métodos de análise, en xeral, diferentes. De todos os xeitos, considerando as vantaxes que estes estudos diacrónicos poderían achegar, son cada vez máis frecuentes os traballos realizados baixo estas perspectivas, sobre todo no caso das historias temáticas: historia da ciencia, da filosofía, etc.

Neste traballo tentarase valorar a recepción da obra e o pensamento de Feijoo en Galicia desde o século XVIII ata actualidade. Ante a complexidade deste tipo de estudos, cómpre sinalar que non vai ser formulado cun carácter exhaustivo e definitivo, senón, máis ben, como unha primeira achega a esta cuestión.

\section{UNHA ACHEGA DE BIBLIOGRAFÍA CUANTITATIVA}

Vanse considerar como material de estudo, primeiramente, libros e artigos, efectuados por galegos ou desde Galicia sobre Feijoo e a súa obra. Para acadar isto tómanse como base as bibliografías recollidas na Biblioteca Virtual Miguel de Cervantes $^{6}$, que remata en 2003 e cun total de 331 citas, das que 33 son publicacións realizadas por galegos; e a de Aguilar Piñal ${ }^{7}$, que finaliza en 1982 e contén 398 citas, delas 94 son galegas. Así mesmo, foi considerada a "Bibliografía» que José Miguel Caso e Silverio Cerra inclúen no Tomo I das súas Obras completas ${ }^{8}$, aínda que, das 1926 citas que contén, unha parte significativa corresponde a

6 Urzainqui, Inmaculada (dir.): Biblioteca virtual Miguel de Cervantes. Benito Jerónimo Feijoo, «Su obra: Bibliografía» (http://www.cervantesvirtual.com/portales/benito_jeronimo_feijoo/su_obra_bibliografia/) [última consulta: 29-10-2015].

7 Aguilar Piñal, Francisco (1981-2001): Bibliografia de autores españoles del siglo XVIII, Madrid, Consejo Superior de Investigaciones Científicas, 10 vols.

8 Caso González, José Miguel / Silverio Cerra Suárez (1981): Benito Jerónimo Feijoo. Obras completas. Tomo I. Bibliografía, Oviedo, Cátedra Feijoo, Centro de Estudios del siglo XVIII. 
obras que non están dedicadas dun xeito específico a Feijoo, pero que si conteñen referencias á súa obra ou ao seu tempo. Posteriormente, as citas galegas foron completadas ata o ano 2014 con outros repertorios bibliográficos investigados (sobre todo a Biblioteca da USC), ata un total de 247 libros e artigos, que se recollen no APÉNDICE BIBLIOGRÁFICO deste traballo. Tamén, e como complemento para o século XVIII, no que foron moi escasas as achegas bibliográficas, examináronse algunhas citas sobre o Padre Mestre rexistrables en obras escritas con outros obxectivos.

Á hora de clasificarmos por períodos de tempo as 245 obras consideradas (exclúense as dúas anteriores a 1750), así como as 331 do repertorio xeral do Cervantes e as 398 de Aguilar Piñal, obtense o seguinte resultado:

Citas bibliográficas, galegas e de ámbito xeral sobre o P. Feijoo

\begin{tabular}{rccc}
\hline & Galegas & Cervantes & Aguilar \\
Data máxima do repertorio: & 2014 & 2006 & 1982 \\
\hline $1750-1799$ & 2 & 4 & 1 \\
$1800-1849$ & 1 & 0 & 1 \\
$1850-1899$ & 59 & 6 & 37 \\
$1900-1949$ & 70 & 19 & 82 \\
$1950-1999$ & 94 & 268 & 277 \\
$2000-2014$ & 19 & 34 & - \\
\hline & 245 & 331 & 398 \\
\hline
\end{tabular}

Este resultado concorda aproximadamente coa afirmación de Freire López ${ }^{9}$ (2003) acerca da recepción de Feijoo no século XIX en España:

Así como fue un best-seller (Feijoo) en el XVIII, en los treinta primeros años del XIX no se hizo una sola edición de sus obras, y apenas sí exiten breves artículos o meras referencias a ellas. La muerte de Fernando VII en septiembre de 1833 no le deparó mejor fortuna. La primera edición del «Teatro Crítico» en el siglo xIx salió a la luz en 1852, y no se trataba de ninguna edición íntegra, sino de una selección de discursos en varios volúmenes, que

9 Freire López, Ana María: Feijoo en el siglo XIX (Concepción Arenal, Emilia Pardo Bazán y Marcelino Menéndez y Pelayo), Alacant, Fundación Biblioteca Virtual Miguel de Cervantes (http://www.cervantesvirtual.com) [última consulta: agosto, 2015]. 
fue sacando a partir de esa fecha, y en años sucesivos $(1853,1859)$ la imprenta de los Hermanos Ayguals de Izco. En 1863 se incluían unas «obras escogidas» en la Biblioteca de Autores Españoles (tomo LVI). Hasta el último cuarto del XIX, coincidiendo con la celebración del centenario de su nacimiento, no hubo trabajos de cierta entidad sobre su vida y su obra.

De todas as formas, e á vista dos datos obtidos para Galicia, pódense efectuar unhas reflexións máis matizadas.

En primeiro lugar, para valorar correctamente estes resultados hai que ponderar en cada intervalo considerado o conxunto de todos os traballos de carácter xeral (libros máis artigos) publicados en Galicia ou por galegos. Como ese dato é totalmente descoñecido, convén utilizar como referencia o dato moito máis xeral, e mellor coñecido, da produción bibliográfica española ou, principalmente, universal. Esta referencia amosa, sempre, un proceso expoñencial de crecemento da produción bibliográfica (duplicable, aproximadamente, cada 10-15 anos) (Price $1956^{10}$ e López Piñero $\left.1972^{11}\right)$, que nos últimos anos semella tender a unha certa estabilización.

A análise dos datos sobre Galicia reflicte que ata a segunda metade do século XIX non se comeza a falar de novo de Feijoo, do mesmo xeito que sinalaba Freire López (2003) para a bibliografía española, e que esta tendencia se evidencia, sobre todo, a partir das conmemoracións concernentes ao segundo centenario do seu nacemento. Estas dúas apreciacións xustificarían que o período que ten unha maior importancia cuantitativa sería 1950-1999, en boa parte por coincidir coa celebración do douscentos aniversario da súa morte, ao que se lle dedicou un congreso de Oviedo (Feijoo y su siglo, 1964), o curso académico 1964-1965 do Ateneo de Santander (Ocho ensayos en torno a Feijoo, 1965), así como na Universidad Nacional de La Plata (Arxentina) Fray Benito Jerónimo Feijoo y Montenegro. Estudios reunidos en conmemoración del IIo Centenario de su muerte (1764-1964), 1965. Nestas tres convocatorias académicas, a presenza de escritores galegos foi moi significativa. Finalmente, se continuase este ritmo de publicacións ata 2049,

10 Price, D. J. de S. (1956): «The Exponential Curve of Science», Discovery, 17, 240-243.

11 López Piñero, José María (1972): El análisis estadístico y sociométrico de la literatura científica, Valencia, Facultad de Medicina, Centro de Documentación e Informática Médica. 
as 19 publicacións dedicadas a Feijoo ata o ano 2014 converteríanse en 49. En suma, estes datos indican o mantemento en Galicia da preocupación sobre o frade de Casdemiro, aínda que en diminución. De todas as maneiras, ao considerar o ritmo expoñencial de crecemento das publicacións no ámbito xeral hai que recoñecer que esta perda de interese pode ser máis importante.

Cando se comparan os resultados galegos cos de carácter xeral, constátanse algunhas diferenzas significativas, entre elas a maior relevancia das citas galegas na segunda metade do XIX e, mesmo, na primeira do século XX. Por outra parte, salienta a desmedida importancia das citas correspondentes ao período 1950-1999 dentro do eido xeral español, que supoñen o $90 \%$ do total no repertorio do Cervantes e o 78 \% no de Aguilar Piñal, mentres nas publicacións galegas só supoñen un 40 \%. (*)

\section{O SÉCULO XVIII}

No repertorio manexado como base deste estudo existen só tres publicacións sobre Feijoo escritas por galegos. Este baixo número habería que relativizalo ao relacionármolo con dous parámetros, as poucas publicacións saídas do prelo neste século e os resultados de ámbito xeral que amosan idéntica escaseza de citas.

Dúas das citas galegas son notas necrolóxicas redactadas polo Padre Noboa, de Samos, e polo Cura de Fruíme, Diego Cernadas de Castro ${ }^{12}$. Amais, dispoñemos dunha terceira, a coñecida Demonstración crítico-apologética del Theatro Crítico Universal $^{13}$, de Martín Sarmiento, na que efectúa unha polémica defensa da obra do seu compañeiro de hábito. É máis, esta alegación en prol de Feijoo e contraria aos ataques recibidos continuouna noutras obras, como, por exemplo, Martinus contra Martinus (1731) e o Papel Satírico (1731) contra Carlos de Montoya y Unzueta, inéditas no seu tempo. Tampouco se pode esquecer a publicación dos

(*) Para o cálculo das porcentaxes tivéronse en conta só as citas anteriores a 1999. Como a bibliografía de Aguilar Piñal remata no 1982, neste caso considerouse a produción estimada para 1999 se a tendencia fose constante.

12 Cernadas de Castro, Diego Antonio (2010): «Ofrenda general para las exequias del muy ilustre Rvdo. P. M. Feijoo. 1774», en Rosa Aneiros Díaz, Xosé López García e Víctor F. Freixanes (eds.), Xornalistas con opinión 2. Escolma de textos, Santiago de Compostela / Vigo, Consello da Cultura Galega / Galaxia, 22-25.

13 Sarmiento, Martín (1739): Demonstración crítico-apologética del Theatro Crítico Universal, Madrid, Imp. Viuda de Francisco del Hierro. 
14 índices das obras de Feijoo, así como as abondosas veces en que Sarmiento aludiu á súa obra.

A Oración Fúnebre ${ }^{14}$, redactada polo Meste Xeral da orde e antigo abade de Samos, Eladio Noboa, é unha ampla peza de 58 páxinas, escrita no clásico estilo encomiástico destes traballos, no que fai un relatorio da vida de Feijoo e das dispares vicisitudes dos seus traballos, con especial atención á boa recepción por parte de determinadas dignidades eclesiásticas. Por outra parte, o escrito do Cura de Fruíme, tamén dentro das constantes tradicionais destas pezas funerarias, ten a orixinalidade de se dirixir a «su muy Noble, muy Respetable y muy Amada la Nación Gallega». E nel destaca que:

El se ha sabido insinuar en el corazón de los mayores hombres y Principes de Europa, y aun fuera de, ella, de tal suerte que ninguno de buen gusto puede pasar sin tenerlo a la vista, quando menos en su viva copia, que son sus escritos, en que está respirando aquel dulce aliento, aquel brillante espíritu, aquel suve agrado, aquel candor ingenuo, aquel talento delicado, aquel perspicaz discernimiento, aquel poderoso atractivo con que enseña, deleyta, mueve,encanta y se hace dueño de los ánimos de todos.

Por último, outra nova referencia a Galicia témola en Feijoo, «Señora, aún después de muerto, os estará dando aquel lustre y brillantez, que os daba de vivo; y la posteridad os dará siempre el parabién de ser madre suya». Aínda que foi publicada en 1774, co conxunto da obra do Cura de Fruíme, debeu de ser do mesmo ano da morte do P. Feijoo, 1764.

Tampouco cómpre esquecer o romance que lle dedicou ao Padre Mestre a dama ourensá D. a Ana María Moscoso de Prado, que foi agradecido por Feijoo nunha carta persoal ${ }^{15}$.

Nun século tan escaso en publicacións como foi o XVIII (sobre todo cando se compara cos seguintes), non pode reducirse só a elas o rastrexo das pegadas

${ }_{14}$ Noboa, Eladio [1765]: Oración fúnebre en las exequias que en 22 de enero de 1765 celebró el Real Monasterio de S. Julian de Samos a su hijo... Fr. Benito Feijoo, Salamanca, Real Casa de Samos, Imp. Antonio Villargordo y Alcaraz.

15 Moscoso del Prado, Ana María (1932): «Romance laudatorio dirigido por Da Ana María Moscoso del Prado al P. Feijóo, y carta de éste a la autora / M. Maciás», Boletín de la Comisión Provincial de Monumentos Históricos y Artísticos de Orense, IX:203, 324-328. 
da obra feijoniana en Galicia. Tanto ou máis importantes poden ser as alusións aos seus traballos na obra dos escritores galegos deste século, nomeadamente as correspondentes aos homes máis sensibles ao pensamento ilustrado (Cornide, Somoza de Monsoriu, Sánchez, Labrada, Cónsul, etc.). Sen chegar a facer unha investigación exhaustiva, a lectura das principais obras destes representantes das luces galegas non amosa citas sobre Feijoo, algo semellante ao que aconteceu con Jovellanos, Floridablanca ou Campomanes. Só o caso do asturiano afincado en Galicia Francisco Cónsul Jove y Tineo, que no libro Ensayo sobre la Hidráulica Rústica ${ }^{16}$ e no seu "Discurso preliminar sobre el estudio y el estado deplorable de la física entre los escolásticos, siendo ésta la base de la felicidad de los Estados», acode a unha cita do beneditino para darlles peso aos seus argumentos en contra das aplicacións a cuestións médicas que realizaban algúns profesores da Universidade de Santiago, «teólogos peripatéticos y filósofos del escotismo»: «Ya lo dijo el P. Feijoo, que aunque toda la Filosofía de las Escuelas, y libros de Aristóteles se pusiesen en un Alambique, no darían una gota de esencia para la Medicina».

Moito máis importantes foron as citas que sobre Feijoo recolle o médico Fernando Oxea, na súa Disertación Médica ${ }^{17}$. Desde a «Breve advertencia apologética», na que xa invoca ao incomparable Feijoo, ata as oito veces que o Padre Mestre é citado, o pensamento e os casos prácticos que considera o beneditino son utilizados como criterio supremo de autoridade. No conxunto da súa obra, en resumo, están presentes os criterios empiristas que defenden Feijoo e outros novatores como Martínez, Piquer ou Valles.

Tamén o médico Pedro Gómez de Bedoya, mestre de Oxea na Universidade de Santiago, foi un dos defensores de Feijoo na devandita institución. Agora ben, na súa obra fundamental Historia universal de las fuentes minerales de Espa$\tilde{n} a^{18}$ (1764-65) cítase escasamente se o comparamos coa profusión coa que se fai referencia nesta obra aos outros novatores que destacaron no eido da medicina

16 Cónsul Jove i Tineo, Francisco (1788): Ensayo sobre la Hidráulica Rústica, Santiago de Compostela, Impr. de Ignacio Aguayo.

17 Oxea, Fernando (1777): Disertación médica de la simplicidad i sencillez con que se debe egercer la medicina, Santiago de Compostela, Impr. de Ignacio Aguayo.

18 Gomez de Bedoya y Paredes, Pedro (1764-65): Historia universal de las fuentes minerales de España, Santiago de Compostela, Imp. de Ignacio Aguayo, 2 vols. 
(Martínez, Piquer, Rodríguez, etc.). E, así mesmo, en palabras de Varela Orol ${ }^{19}$, a defensa de Feijoo na Universidade de Santiago estaría representada tamén pola obra do P. Santos Bello gusto de moda.

Finalmente, outro dato interesante para avaliar en que medida repercutiu a obra e o pensamento de Feijoo na sociedade galega do XVIII é a presenza nas bibliotecas públicas ou privadas das obras do Padre Mestre. Da Universidade de Santiago sábese que en 1774 eran mercadas polo bibliotecario Valle-Inclán ao libreiro Sancha e Alberá e que existían tamén en moitas bibliotecas conventuais (Rey Castelao $2003^{20}$ ). No tocante ás bibliotecas privadas investigadas, existen exemplares das obras de Feijoo na do arcebispo Muzquiz, así como en pazos como os de Oza, Viloria ou de Casaldireito, no Ribeiro ${ }^{21}$. Pódese intuír, polo tanto, a relativa frecuencia das obras de Feijoo no século XVIII tanto nas bibliotecas institucionais galegas como naquelas pertencentes ao alto clero e aos nobres e fidalgos cun certo nivel cultural.

\section{O SÉCULO XIX}

Como sinalan Gregorio Marañón (1934) 22 , Freire López (1996) ${ }^{23}$ e Barreiro Fernández $(2003)^{24}$, na primeira metade do século practicamente non hai citas sobre Feijoo e as poucas existentes corresponden a estranxeiros como Laborde (1808) ou Blanco White (1822). Semella como se o alento renovador do beneditino, tan valorado no século anterior, caese nun esquecemento forzado, que nin sequera os contados períodos liberais dese tempo conseguiran restablecer. Este escurece-

19 Varela Orol, Concha (2001): «"Quien no moliniza janseniza”. Lecturas prohibidas nas bibliotecas compostelanas», en Xosé Luís Barreiro (coord.), Ilustración e modernidade: os avatares da razón, Santiago de Compostela, Universidade, 107-158.

${ }^{20}$ Rey Castelao, Ofelia (2003): Libros y lectura en Galicia: siglos XVI-XIX, Santiago de Compostela, Xunta de Galicia.

21 Saavedra, Pegerto (2011): «A cultura pacega. Algunhas mostras», en Javier Barcia González (ed.), Fidelidade á terra: estudos dedicados ó profesor Xosé Luis Barreiro Barreiro, Santiago de Compostela, Universidade, 287-312.

22 Marañón, Gregorio (1954): Las ideas biológicas del Padre Feijóo, Madrid, Espasa Calpe, $3^{\mathrm{a}} \mathrm{ed}$.

23 Ver nota 9.

${ }^{24}$ Barreiro Fernández, Xosé Ramón (2003): «O estudio crítico das obras do P. Feijóo, de Pardo Bazán, Concepción Arenal e Miguel Morayta. O certame de Ourense de 1878», La Tribuna, I:1, 47-96. 
mento da obra de Feijoo nas primeiras décadas do XIX podería deberse, en parte, á hostilidade dos románticos cara á Ilustración, que era cualificada despectivamente, dun lado como "clerical e timorata» e, doutro, como «arriscada e heterodoxa» (Galech 2010) 25 .

En España, a recuperación da figura do Padre Mestre comezaría en 1852 coa reedición do Teatro Crítico e, sobre todo, cos estudos que se lle dedicaron co gallo da celebración do segundo centenario do seu pasamento. De todas as maneiras, foi unha recuperación moi lenta cuantitativamente, que só alcanza un crecemento importante na segunda mitade do século XX, cen anos despois. Posiblemente, o restablecemento da obra de Feijoo correu paralelo ao interese que para os historiadores foi adquirindo o período ilustrado por se considerar un dos momentos en que a vida española comeza a manifestar unha nova vitalidade e un desexo de non perder o tren da cultura europea, maiormente no relativo á polémica sobre a Ciencia en España.

En Galicia, o espertar dun sentimento positivo cara á figura do Padre Mestre foi máis importante e adiantado que no resto de España (as citas galegas no século XIX supoñen un $24 \%$ fronte ao total, mentres que en España, segundo os repertorios, foron do 2 ou $9 \%$ ). A pesar de non se poder realizar unha comparación estrita dos datos, a causa de as citas corresponderen con repertorios diferentes, as diverxencias entre eles son significativas, ata o punto de non existiren dúbidas sobre a singularidade que presenta a recuperación da obra de Feijoo no ámbito galego en comparación co xeral, español. En opinión de Barreiro Fernández (1996), a razón desta peculiaridade galega pode residir na importancia que a primeira xeración de escritores galeguistas (os provincialistas) lle deron á figura de Feijoo. Nela atopaban un referente identitario que destacaba con luz propia no universo cultural español e que enlazaba perfectamente coa procura dunha historia de Galicia ben asentada en personalidades indiscutibles e de renome universal.

O punto de partida para rehabilitar a memoria do Padre Mestre en Galicia foi o traballo de Antolín Faraldo ${ }^{26}$, recollido en 1842 nas páxinas de El Recreo

25 Galech Amillano, Jesús María (2010): Astrología y medicina para todos los públicos: las polémicas entre Benito Feijoo, Diego de Torres y Martín Martínez y la popularización de la ciencia en la España de principios del siglo XVIII, Barcelona, Universitat Autònoma de Barcelona, tese de doutoramento.

${ }^{26}$ Faraldo, Antolín (1842): «Filósofos gallegos. Feijoo», El Recreo Compostelano, 3, 30-37; «Feijoo», El Recreo Compostelano, 6, 85-88. 
Compostelano dentro dunha sección dedicada aos filósofos galegos. Estamos diante dun texto bastante amplo, inconcluso pola desaparición da revista, que se enriquece cun gravado relativamente bo e que comeza cunha clara afirmación galeguista: «Porque el mayor sabio español del siglo 18 ha sido gallego». Fai unha boa descrición da vida e da calidade da obra do beneditino, incluíndo curiosas referencias, como a que fai en clave frenolóxica, pseudociencia daquela de moda («Dotado de una penetración profunda: de una memoria prodigiosa — que el frenólogo debe notar con atención, pues está manifestada en los ojos grandes que ofrece su retrato») ou á súa capacidade de traballo («una aplicación a las tareas literarias, que solo tenía de interrupción cuatro horas al día»).

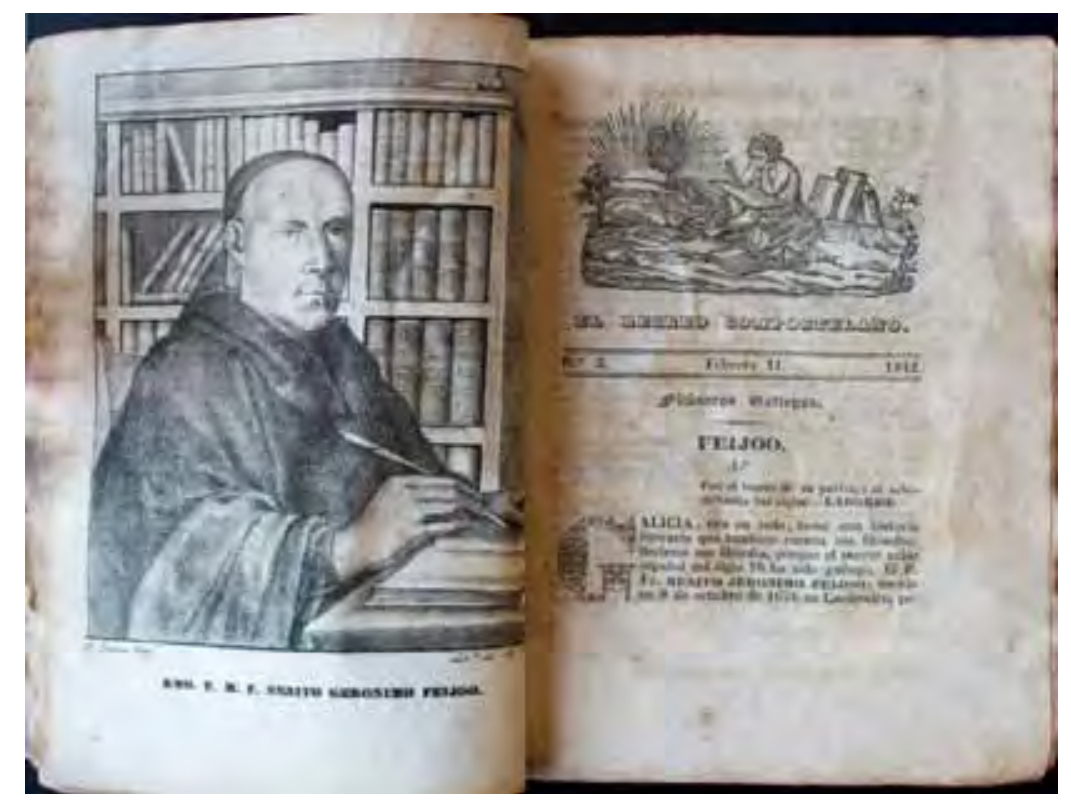

Artigo de Antolín Faraldo sobre Feijoo en El Recreo Compostelano (1842)

Despois desta temperán mención, está o traballo do avogado coruñés Pelayo Catoira ${ }^{27}$, aparecido en Galicia. Revista Universal de este Reino en 1860. Nel, láiase de que en Galicia non se fixese a lembranza de Feijoo, como acontecera naquela altura en Salamanca con Frei Luis de León, erixíndolle un monumento («Aquel

${ }^{27}$ Catoira, Pelayo (1860): «Fr. Benito Gerónimo Feijóo», Galicia. Revista Universal de este Reino, I:5, 76-77. 
pensamiento era la evocación de otra tumba, olvidada también, durante cien años, pero tan santa para España, relicario de veneración para Galicia... Aquella tumba es tuya ¡oh Galiciaj porque allí están los despojos que te dejó la muerte de Fr. Benito Feijoo»). Tamén aproveita para sinalar a proposta recente de «un joven artista» na Revista Económica, de Santiago, consistente no levantamento dunha estatua a Feijoo por iniciativa da Universidade de Santiago e da prensa local. Deste xeito, «canonizaremos como buenos gallegos la memoria de tan esclarecido compatriota». Pero vai ser sobre todo Manuel Murguía, apoiado no incuestionable prestixio intelectual do que gozaba en Galicia, quen sitúe a Feijoo como un dos alicerces do seu renacer cultural. No Diccionario de escritores ${ }^{28}$ destaca o papel sobranceiro que exerceron Feijoo xunto con Sarmiento como adiantados dunha tradición cultural, que enraizaba e lle daba soporte á pulsión identitaria defensora do movemento rexionalista, do que Murguía era un dos máis recoñecidos ideólogos.

O punto álxido da recuperación do beneditino chegou coa celebración da efeméride en Ourense do segundo centenario do seu nacemento en 1877. Neste simposio, Barreiro Fernánde ${ }^{29}$ informou dos detalles e do significado deste acontecemento.

En 1875, o claustro do Instituto de Ourense alertaba da proximidade do bicentenario e solicitaba ás autoridades que se celebrase con toda solemnidade. Nesta efeméride saliéntase a realización dun Certame público, coa participación de figuras da importanica de Emilia Pardo Bazán e Concepción Arenal. A polémica e as repercusións que suscitou a decisión do xurado, así como a difusión posterior dos textos das autoras galegas, contribuíron a popularizar en España a obra e o pensamento de Feijoo.

Os ecos desta efeméride non se apagaron coa resolución do Certame, xa que coetánea del foi a iniciativa de lle erixir unha estatua a Feijoo en Ourense por subscrición popular que xa fora alentada en 1876 por Curros nun dos seus poemas (Alonso Montero $1966^{30}$ ):

${ }_{28}$ Murguía, Manuel (1862): Diccionario de escritores gallegos, Vigo, Juan Compañel.

${ }^{29}$ Ver neste mesmo volume o texto de Xosé Ramón Barreiro Fernández, «Ollada crítica sobre a obra de Feijoo de dúas intelectuais galegas: Concepción Arenal e Emilia Pardo Bazán», pp.

30 Alonso Montero, Jesús (1966): «Feijoo y Curros Enríquez», en El P. Feijoo y su siglo. Ponencias y comunicaciones presentadas al Simposio celebrado en la Universidad de Oviedo del 28 de Septiembre al 5 de Octubre de 1964, Oviedo, Universidad, vol. 1, 33-36. 
Del recio polvo que mancharte pudo

vas a exhumar el ídolo olvidado...

al colocarlo en el altar Sagrado.

Naquela altura, El Heraldo Gallego, xornal ourensán que dirixía Valentín Lamas Carvajal, realizou unha intensa campaña co obxecto de promover o coñecemento do bieito galego. Un dos xermolos destacables foi a publicación en 1876 de $\mathrm{La}$ aldea de Casdemiro. Álbum literario dedicado á la inmortal memoria del ilustre crítico Padre Feijóo $o^{31}$, con colaboracións de J. M. Hermida, Teodosio Vesteiro, Juan Manuel Paz Novoa, J. M. Somoza de la Peña, J. Muruais, Manuel Curros Enríquez, J. A. Saco y Arce, R. Vázquez, L. Rodríguez Seoane, Valentín Lamas Carvajal e Emilia Calé y Torres.

Ademais disto, a comisón para o monumento encargoulle a Curros en 1879 un apropósito teatral sobre a figura de Feijoo para que fose representada pola compañía do aragonés Luis Blanc, daquela de xira por Galicia. Foi escrita polo poeta de Celanova en poucas horas e representada con moito éxito. De feito, poucos meses despois foi posto de novo en escena por unha compañía local. Nesta obra, Curros presenta na terceira escena a un Feijoo coas Cartas eruditas na man, pronunciando unha diatriba contra os defensores do escurantismo:

$$
\begin{aligned}
& \text { Partidarios del error } \\
& \text { en cuya noche sombría } \\
& \text { huerfano el pueblo gemía } \\
& \text { sin norte y sin redentor. }
\end{aligned}
$$

Típica do século XIX, esta figura, democrática e populista, distinguíase por unha visión moi aberta do celibato eclesiástico. Incluso, agradecíanselle os beneficios que os seus consellos reportaban aos agricultores ("Gracias a sus libros, gracias / a sus agudos consejos / sobre el cultivo del campo, / tenemos los graneros / llenos...») (Alonso Montero 1966).

31 La Aldea de Casdemiro. Album literario dedicado á la inmortal memoria del ilustre crítico Padre Feijóo, publicado por El Heraldo Gallego con al colaboración de distinguidos escritores (1876), Ourense, Imp. de La Propaganda Gallega. 


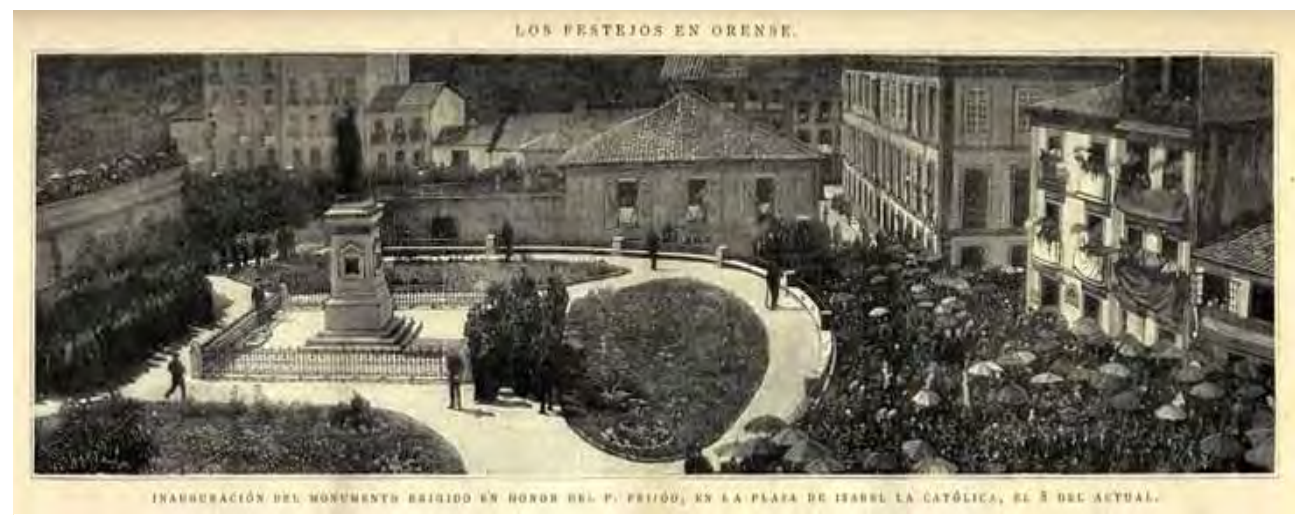

Inauguración en Ourense da estatua do Padre Feijoo (1887)

Finalmente, o 8 de setembro de 1887, despois de doce anos de espera, inaugurouse no centro de Ourense a estatua de Feijoo, deseñada por Zabala e modelada polo catalán Juan Soler (Otero Túñez 1966 ${ }^{32}$ ). Houbo festas cinco días e estimouse a asistencia en 20000 persoas (o dobre da poboación da cidade daquela altura). Os fastos en forma de certame literario e científico, concurso de orfeóns, feira e concurso de gando, fogos de artificio, etc. contribuíron ao non esquecemento do acontecemento en moito tempo. Manuel Pereiro Rey, home de negocios ourensán e presidente da Comisión pro Monumento, puido, por fin, descansar tranquilo e comprobar que o diñeiro que achegara (quizais menos do que se falou) e, sobre todo, os desvelos e contratempos que tivo que aguantar tiñan finalmente o seu recoñemento. Ao día seguinte, houbo un acto solemne na catedral, no que Marcelo Macías leu un notable discurso de glosa do Padre Mestre.

En síntese, e ao abeiro da permanente e intensa dedicación á difusión dos acontecementos por parte de El Heraldo de Orense, estas celebracións tiveron un marcado acento ourensán. Non obstante, o resto de Galicia tampouco foi indiferente a eles. Neste senso, pódense destacar o manifesto da Universidade de Santiago, asinado polo reitor, Antonio Casares, «invitando a los alumnos a

32 Otero Túñez, Ramón (1966): «Iconografía del Padre Feijoo: esculturas», en El Padre Feijoo y su siglo. Ponencias y comunicaciones presentadas al Simposio celebrado en la Universidad de Oviedo del 28 de septiembre al 5 de octubre de 1964, Oviedo, Universidad, vol. 3, 551-559. 
concurrir al Certamen Literario en honor del P. Feijoo», así como a circular do gobernador de Lugo, dirixida á Deputación e concellos da provincia, co fin de que «cooperen, como sus recursos lo permitan, a dar esplendor al Certamen Literario...».

Un trazo característico deste período foi o da presenza da obra de Feijoo nas publicacións que comezaban a editar as comunidades galegas americanas. Viña motivado por unha necesidade, similar á dos movementos rexionalistas, de atopar na historia galega persoeiros singulares e de recoñecido prestixio, máis agrandada agora pola saudade da patria distante. Foron varias as que recolleron descricións do beneditino e publicáronse extractos da súa obra, como «El P. Feijoo» (1887), «La casa solariega del P. Feijoo» (1887), saídos nas páxinas de Galicia Moderna (A Habana), ou «El P. Feijoo» (1895), en La Tierra Gallega, tamén da Habana. Sen dúbida, os diferentes estudos feitos sobre a presenza de Feijoo en América (Palacio Artad $1966^{33}$, Filgueira Valverde $1971^{34}$, etc.) non deberían esquecer este xeito peculiar de recoñecemento da súa figura alén dos mares.

De todo o dito habería que concluír que a importante diferenza cuantitativa, neste período, entre as publicacións sobre Feijoo feitas por galegos e as restantes españolas foi debida, primeiramente, á transcendencia que acadou a súa figura, sobre todo en Ourense, pola convocatoria do Certame literario e a erección dunha estatua, e, secundariamente polas publicacións galegas de alén mar. Evidentemente, estes feitos non tiveron o seu paralelismo no resto de España.

\section{O SÉCULO XX}

Este período acumula o maior número de traballos sobre Feijoo, nomeadamente fóra de Galicia. Por iso, desde un punto de vista sistemático é aconsellable dividilo en dúas partes: a das publicacións anteriores á Guerra Civil e as editadas desde o seu remate ata finais de século.

33 Palacio Artad, Vicente (1966): «La influencia del P. Feijoo en América», en El P. Feijoo y su siglo, Oviedo, Universidad, vol. 1, 21-31.

34 Filgueira Valverde, Xosé (1971): El Padre Feijoo y los españoles americanos, Pontevedra, Imp. Hogar Provincial. 
En España, a pesar das citas de intelectuais de prestixio como Azorín (1913) ${ }^{35}$ ou Pérez de Ayala $(1918)^{36}$, a característica máis sobranceira foi, en xeral, o silencio en que seguiu sumido o intelectual ourensán ata a chegada da renovación intelectual dos anos vinte. A partir dese momento, sucédense unha serie de feitos singulares que volven poñer a Feijoo na axenda cultural española. Como é o caso, por exemplo, do interese que demostra a Revista de Occidente con diversos textos (Salinas $1924^{37}$ e Marañón y Posadillo $1933^{38}$ ); a preocupación pola obra da man de escritores doutras nacionalidades, como o catalán Carreras Artau (1930) ${ }^{39}$; a recepción da obra do francés Delpy ${ }^{40}$ no volume L'Espagne el l'espirit européen. L'oeuvre de Feijoo (1726-1760), e, sobre todo, as repetidas achegas por parte de Gregorio Marañón, que culminarían coa publicación de Las ideas biológicas del Padre Feijoo pola prestixiosa Editorial Espasa (Madrid, 1934). Tampouco habería que desbotar, como dato significativo, o interese dalgúns intelectuais americanos, como foi o caso de Antonio Rubio, autor en $1937^{41}$ de La crítica del galicismo en España desde Feijoo a Mesonero (1726-1832).

Pola súa parte, a centuria comeza en Galicia con dúas publicacións importantes: Los escritos de Sarmiento y el Siglo de Feijoo (López Peláez 190142) e Poesías inéditas del P. Feijoo (Areal 190143), na que se recuperan 40 poemas inéditos procedentes do convento de Lérez. Despois delas, o silencio esténdese por toda España. Chegados os anos vinte, Marcelo Macías ${ }^{44}$ retoma a poesía de Feijoo no Boletín de la Comisión Provincial de Monumentos Históricos y Artísticos de Orense (1926). Sen saírmos de 1926, Ourense, como non podía ser menos, conmemora

35 Azorín (1921): Los valores literarios, Madrid, Rafael Caro Regiol. (Obras completas; 11).

36 Pérez de Ayala, Ramón (1918): Política y toros. Ensayos, Madrid, Calleja.

37 Salinas, Pedro (1924): «Feijoo en varios tiempos», Revista de Occidente, III:8, 259-265.

38 Marañón y Posadillo, Gregorio (1933): «Revisión de la historia del hombre-pez», Revista de Occidente, XLII:125, 162-183.

39 Carreras Artau, Tomás e Joaquín (1935): Feijoo y las polémicas lulianas en el siglo XVIII, Madrid, Bermejo. XIV Congreso Asoc. Española Progreso de las Ciencias (Santiago, 1934).

40 Delpy, G. (1936): L'Espagne et l'esprit européen. L'oeuvre de Feijoo (1725-1760), París, Librairie Hachette.

41 Rubio, Antonio (1937): La crítica del galicismo en España desde Feijoo hasta Mesonero (1726-1832), México, Universidad Nacional Autónoma.

42 López Peláez, Antolín (1901): Los escritos de Sarmiento y el siglo de Feijoo, A Coruña, Andrés Martínez Salazar. (Biblioteca Gallega).

43 Areal, Justo Eliseo (1901): Poesías inéditas del Padre Feijoo, Tui, Tip. Regional.

44 Macías y García, Marcelo (1926): «Feijoo, poeta», Boletín de la Comisión Provincial de Monumentos Históricos y Artísticos de Orense, VII:170, 438-448. 
cun Certame Literario a «gloriosa efeméride» do bicentenario da publicación do Teatro Crítico.

Cinco anos despois, a achega máis relevante sobre Feijoo foi Galicia en el Padre Feijoo, conferencia de Santiago Montero Díaz publicada en 1931. Neste traballo, ben documentado, repásase a presenza de Galicia nas súas publicacións con novas ideas e formulacións, que de feito atinxen toda a obra do beneditino. Chama a atención a imaxe dun Feijoo «galleguista, patriota e demócrata» nesta conclusión:

Preocupado de los temas universales, pero también de los regionales dolores; maestro de la España pensante, pero también apostol de la Galicia sufriente; admirador de cuanto en el mundo ha sido grande y benéfico, pero también conocedor de cuanto Galicia ha realizado en la historia de Europa; maestro universal del siglo XVIII, y por universal y por maestro, gallego sobre todas las cosas.

En 1932, Montero Díaz, en Las ideas estéticas de P. Feijoo ${ }^{45}$, fai unha atinada crítica das persoas que falan da "gran cultura pero perverso gusto de Feijoo», así como da súa "escasa sensibilidad para las artes y la poesía», amosando con novos e agudos argumentos os valores estéticos detectables nas súas obras.

Destes mesmos tempos, contamos con traballos de intelectuais da importancia de Cotarelo Valledor, que nas páxinas de Nós publicou «A mocedade do P. Feixoo» (1930), e Otero Pedrayo, quen iniciou os múltiples estudos dedicados ao Padre Mestre co artigo sobre "A saudade do P. Mestre», dado a coñecer en El Pueblo Gallego en 1935.

Alén mar, concretamente no Brasil, o artista compostelán Modesto Brocos publicou un curioso libro sobre un mundo futuro, localizado en Marte, onde se materializaban os ideais socialistas. Co título Viaje a Marte (Valencia, 1930) ${ }^{46}$, relata a viaxe do autor ao planeta vermello, no que o frade Feijoo, nesta nova reencarnación, lle serve de guía e mentor. Ao final do libro, o beneditino é descrito como "o primeiro socialista» ${ }^{47}$.

\footnotetext{
45 Montero Díaz, Santiago (1932): «Las ideas estéticas del Padre Feijóo», Boletín de la Universidad de Santiago de Compostela, IV:15, 3-95.

46 Brocos, Modesto (1930): Viaje a Marte, Valencia, Ed. Artes y Letras.

47 Jaureguízar, Agustín (2009): «El Viaje a Marte de Modesto Brocos», Arbor, CLXXXV:740, 1313-1322.
} 
Finalmente, para este período do século Xx, que precedeu á Guerra Civil española, foi tamén moi singular a presenza de Feijoo nas publicacións da emigración galega en América. Cunha frecuencia e importancia superior ás do período precedente, foron aparecendo recensións ou treitos das obras de Feijoo en todas as revistas ou, sobre todo, referencias e artigos encomiásticos tanto da súa obra coma do seu significado como símbolo egrexio da nosa historia como pobo. Algúns traballos témolos en Aires da miña terra (1908), Suevia (1913), Centro Gallego (1918), Almanaque Gallego (1923), Céltiga (1926), Alma Gallega (1937), etc.

Despois dos actos e publicacións concernentes ao seu centenario, a popularidade de Feijoo en Galicia foi medrando progresivamente. En concreto, o feito de lle poñeren o seu nome a numerosas rúas e prazas foi obxecto de atención polo escritor portugués Fialho de Almeida no relato da viaxe realizada por Galicia en 1905 (Cadernos de viagem, 199648): «Em Rivadeo, como em todas as terras da Galiza, a calle Feijoo, ... são coisas obrigadas».

O maior número de obras relativas ao intelectual ourensán procede, sen lugar a dúbidas, do período comprendido entre o final da Guerra Civil e o remate do século. Deixando á marxe o feito de ser o intervalo máis abundante de produción bibliográfica en xeral, desenvolvéronse un conxunto de circunstancias favorables en España. Por unha parte, na Universidade de Oviedo créase en 1954 a Cátedra Feijoo, instituída polo Concello desa cidade, que en 1972 se transforma no Centro de Estudios del siglo XVIII, en 1987 no Instituto Feijoo del siglo XVIII e, finalmente, no ano 2005 adquire o rango de Instituto Universitario. Este organismo promoveu a revista Cuadernos de la Cátedra Feijoo e a realización dunha serie de congresos e reunións científicas, que, directa ou indirectamente, tiñan como obxectivo a vida e a obra do beneditino.

Con motivo do II centenario do seu pasamento, en 1964, os estudos recibiron unha importante achega cuantitativa e cualitativa. Unha desas mostras foi o congreso Feijoo y su siglo, que tivo lugar en Oviedo. A este evento hai que lle sumar o curso 1964-1965 do Ateneo de Santander, dedicado a conmemorar a obra do beneditino, e unha serie de estudos efectuados na Universidad Nacional de La Plata (Bos Aires).

48 Almeida, Fialho de (1996): Cadernos de viagem. Galiza, 1905, Santiago de Compostela, Laiovento. (Vento do Sul). 
Tamén puido influír na proliferación dos estudos feixonianos o feito de que o século XVIII e, máis en concreto, a Ilustración pasou a ser un tema importante e de crecente interese para a intelectualidade española (historiadores, economistas, científicos, etc.). De ser unha época histórica relativamente escura, foise pasando a ser considerada como un período apaixonante e necesario para entender os avatares da modernidade en España grazas aos traballos de Domínguez Ortiz $(1955)^{49}$, Herr $(1964)^{50}$, Anes (1969) $)^{51}$, Elorza $(1970)^{52}$ ou Sarrailh $(1974)^{53}$. Máis adiante, o clima da Transición, que tentaba atopar novos alicerces para inserir o pensamento español coas correntes europeas, así como a conmemoración do II aniversario da morte de Carlos III axudaron a popularizar estes contributos e a crear un ambiente favorable para a súa recepción.

En Galicia, non foi menor a preocupación con relación á centuria XVIII, sobre todo da man dos historiadores herculinos Martínez Barbeito e Meijide Pardo, que desde os anos sesenta se viñeron preocupando por problemas de historia local e económica. A partir dos anos setenta, os economistas descubriron a importancia do pensamento ilustrado como un dos primeiros intentos de racionalización da nosa economía (Dopico $1978^{54}$ e Beiras $1972^{55}$ ) e, finalmente, na altura dos oitenta foron os filósofos os que se preocuparon pola importancia deste período na historia do pensamento galego (Barreiro 199356), dentro do cal Feijoo foi considerado como un dos máis importantes referentes da Ilustración.

49 Domínguez Ortiz, Antonio (1955): La sociedad española en el siglo XVIII, Madrid, Instituto Balmes de Sociología. (Monografías histórico-sociales).

50 Herr, Richard (1964): España y la Revolución del siglo XVIII, Madrid, Aguilar. (Cultura e Historia).

51 Anes, Gonzalo (1969): Economía e Ilustración en la España del siglo XVIII, Barcelona, Ariel. (Ariel quincenal; 19).

52 Elorza, Antonio (1970): La ideología liberal en la Ilustración española, Madrid, Tecnos.

53 Sarralih, Jean (1974): La España ilustrada de la segunda mitad del siglo XVIII, México, Fondo de Cultura Económica. (Historia).

54 Dopico Gutiérrez del Arroyo, Fausto (1978): A Ilustración e a sociedade galega. A visión dos economistas ilustrados, Vigo, Galaxia. (Alén Nós).

55 Beiras, Xosé M. (1973): «Notas previas para una Economía Política de la "Ilustración Gallega”, en Pedro Antonio Sánchez Vaamonde, La economía gallega en los escritos de Pedro Antonio Sánchez, Vigo, Galaxia, pp. 7-31. (Os Precursores).

56 Barreiro, Xosé Luís (coord.) (1997): Sonos e soños da razón. A Ilustración nas coleccións da Biblioteca Universitaria de Santiago de Compostela. Exposición e simposio Ilustración e educación en Galicia, Santiago de Compostela, Universidade. 
De calquera forma, bastante antes da chegada desta valoración do movemento ilustrado e do correspondente interese suscitado nos investigadores, houbo unha serie de actos e publicacións que non se deben esquecer.

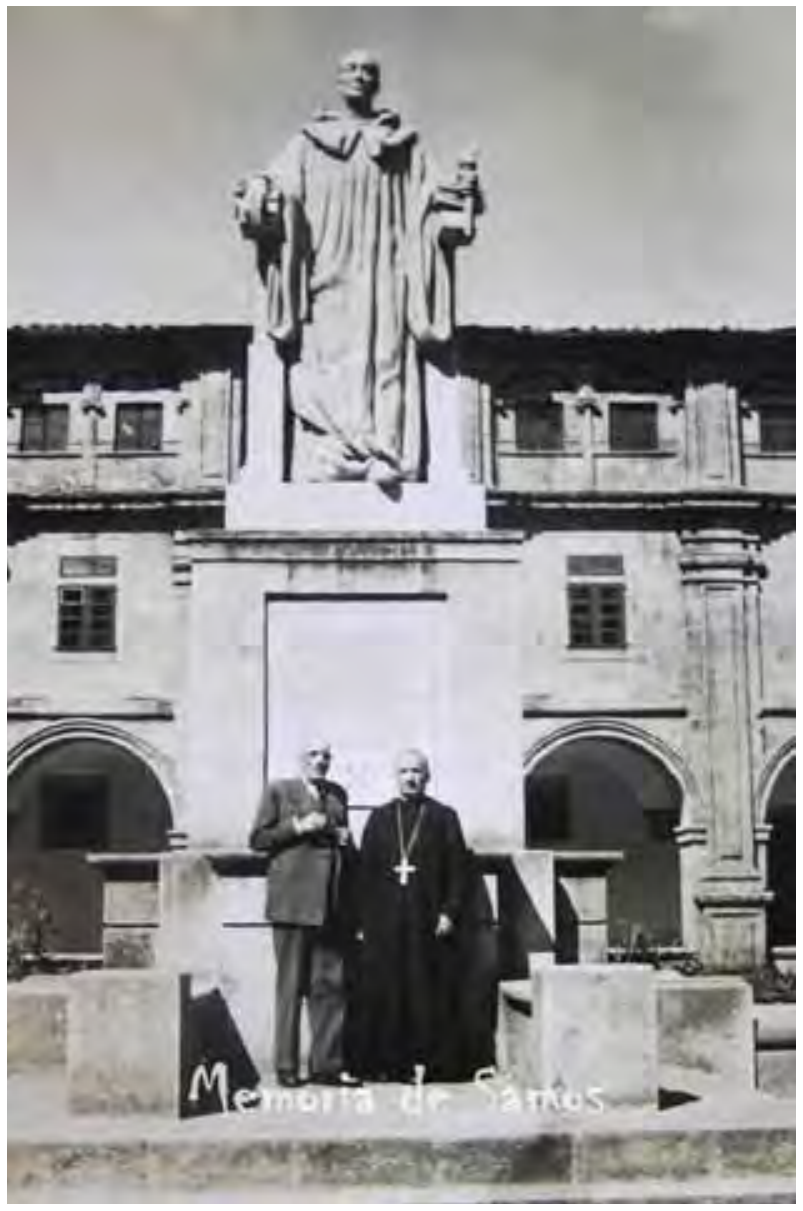

Ramón Cabanillas e o abade Mauro Gómez diante da estatuta a Feijoo en Samos.

En primeiro lugar, a inauguración da estatua, realizada por Asorey, no gran claustro do mosteiro de Samos. Foi unha iniciativa que dera os seus primeiros pasos antes da Guerra Civil, pero que non callou ata despois da contenda grazas a una comisión, baixo a presidencia de Gregorio Marañón e con Santiago Montero Díaz en calidade de secretario. Inagurouse con toda a solemnidade 
o 24 de agosto de 1947, sendo abade de Samos Mario Gómez Pereira. Ao seguinte ano, chegaba ao mosteiro Ramón Cabanillas para iniciar a que sería unha longa e afectiva relación con este lugar. Semella que ao pouco comezou o poema «Samos»" ${ }^{57}$, o seu derradeiro traballo. Nel, dedícalle unhos sentidos versos á estatua:

\author{
Mentras no pedestal, inmobre, erguido, \\ surrí bondadoso e escoita compracido \\ noso Padre Feixóo, o mestre aceso \\ pola Verdade, alleo ó prexuicio, \\ que aquí xogou novicio \\ e visteu a cogulla de profeso; \\ o gran gallego de visión certeira \\ e pruma sabia, crítica e recoita, \\ que aquí atopou repouso a canseira \\ do longo enseño e da esforzada loita.
}

A partir deste acontecemento comeza en Samos unha singular preocupación intelectual por Feijoo. Destaca a serie de artigos do frade Narciso Pérez co encabezamento «El Padre Feijoo y las Ciencias Naturales»" ${ }^{58}$, premiados pola Academia de Ciencias Físicas y Naturales e dados a coñecer na súa revista, e as publicacións propias da abadía, que foron editadas en datas próximas ao seu segundo centenario. Entre elas están El Padre Feijoo y su monasterio de Samos (1966), de Victoriano González, e El Padre Feijoo. Su magisterio. Antología de sus obras (1967), de Sara Leirós Fernández.

En liña con este fervor feixoniano, a Universidade de Santiago organiza un curso de verán, en 1947, sobre «El siglo XVIII español», no que os relatorios de L. Sánchez Agesta e A. Valbuena Prat foron dedicados explicitamente ao beneditino e nos outros, de carácter máis xeral, foi unha referencia constante.

57 Cabanillas, Ramón (2009): Samos, Vigo, Xerais. (Biblioteca das letras galegas; 65).

58 Pérez, Narciso (1947): «El Padre Feijoo y las Ciencias Naturales (Un capítulo de historia de la Ciencia española)", Revista de la Real Academia Ciencias Exactas Físicas y Naturales, 119-124, 287-336, 469-513, 599-643. 
A outra estatua erixida a Feijoo en Galicia, obra do escultor Faílde, inaugurouse en 1961 en Allariz, terra dos seus antepasados. Amósanos un frade novo e pensativo, como ollando cara ao chan.

Manuel Casás, noutrora presidente da Real Academia Galega, dedícalle tamén dous artigos no Boletín de la Real Academia Gallega («El P. Feijoo juzgado en su tiempo», 1950, e «El P. Feijoo y la justicia», 1952) e Ramón Otero Pedrayo continúa o seu labor investigador e divulgativo sobre o Padre Mestre con artigos en El Pueblo Gallego («El delirio del Padre Maestro», 1943), La Noche («El P. Feijoo a través de Concepción Arenal», 1946), Aturuxo («Fray Benito Jerónimo Feijoo», 1952) ou La Región («iAdios Padre Maestro!», 1958).

Finalmente, habería que destacar tamén para este período o capítulo de Baltar Domínguez referido a Feijoo no seu clásico libro Opúsculos médicos gallegos del siglo XVIII (1961) ${ }^{59}$ e a colaboración de Sánchez Cantón cos acabados de crear na Universidad de Oviedo Cuadernos de la Cátedra Feijoo (Ideas de los PP. Feijoo y Sarmiento sobre la organización de los estudios, 1961) ${ }^{60}$. Paralelamente, as publicacións da emigración continúan co labor divulgador sobre Feijoo (Saudade, 1944; Alma Gallega, 1947; Lar, 1960, etc.) e, sobre todo, a referencia que se fai del en Alba de Groria (1948). Neste emocionante manifesto galeguista, a última intervención pública de Castelao no Día de Galicia en Bos Aires, imaxina unha Santa Compaña composta de «galegos inmortaes», como Feijoo e Sarmiento, «que remediaron o atraso cultural de España coa súa poderosa erudición e o seu xenio enciclopédico».

A participación galega nas actividades académicas que se celebraron en 1964 para conmemorar os douscentos anos do pasamento do Padre Feijoo foi destacada. No simposio realizado en Oviedo sobre El Padre Feijoo y su siglo (1966) participaron Alonso Montero cun traballo sobre Curros, José Luis Varela (1966) sobre a «literatura mixta» en Feijoo ${ }^{61}$ e Otero Túñez sobre a iconografía feixoniana. Máis importantes, relativa e cuantitativamente, foron as achegas

59 Domínguez Ortiz, Antonio (1955): La sociedad española en el siglo XVIII, Madrid, Instituto Balmes de Sociología. (Monografías histórico-sociales).

60 Sánchez Cantón, Francisco Javier (1961): Ideas de los PP. Feijoo y Sarmiento sobre la organización de los estudios, Oviedo, Universidad, Facultad de Filosofía y Letras. (Cuadernos de la Cátedra Feijóo; 10).

${ }^{61}$ Varela, José Luis (1966): «La "literatura mixta" como antecedente del ensayo feijoniano», en El Padre Feijóo y su siglo, Oviedo, Universidad, 79-88. 
galegas ao Curso organizado polo Ateneo de Santander, publicado como Ocho ensayos en torno a Feijoo (1965), xa que dos oito conferenciantes tres eran galegos: Juan Rof Carballo («Medicina crítica y medicina comprensiva en la obra del P. Feijoo»), Dionisio Gamallo Fierros («La poesía de Feijoo») e Ramón Otero Pedrayo («Coordenadas históricas de la vida del P. Feijoo»). Nos estudos dedicados pola Universidad Nacional de La Plata a Feijoo tamén foi notable a presenza galega con traballos como o de Luís Seoane, sobre a estética de Feijoo en relación cos movementos renovadores da arte contemporánea, ou os dous referidos á medicina da época, de F. García Armesto e de Sánchez Guisande. Cómpre destacar tamén o pouco coñecido debuxo de Díaz Pardo sobre Feijoo, que se reproduce no comezo da publicación destes estudos.

En Galicia, esta conmemoración tivo menor repercusión ca as convocadas no século XIX, que daquela foron, posiblemente, as máis importantes das realizadas en España. Só merece sinalarse o Certame literario sobre a figura de Feijoo, convocado polo recentemente creado Instituto de Estudios Orensanos, que foi gañado por Otero Pedrayo coa súa obra El Padre Feijoo. Su vida, doctrina e influencias. O segundo premio correspondeulle a A. Pérez-Rioja co traballo Proyección y actualidad de Feijoo. Oito anos despois, en 1972, publicouse a monumental obra de Otero, que pode ser considerada pola súa magnitude e visión do Padre Mestre como unha das grandes referencias sobre Feijoo no século XX.

Estimuladas pola resonancia que acadou Feijoo cos actos do segundo centenario do seu óbito, apareceron un conxunto bastante amplo de publicacións en diversos medios feitas por importantes persoeiros da cultura galega como Eduardo Blanco-Amor, con El Padre Feijoo, tema con variaciones (1966); Xosé Luís Barreiro Barreiro, coa Defensa das mulleres (1967); Xosé Luís Pensado, con Feijoo e Sarmiento. Dúas vidas sen paralelismo (1967); Juan Rof Carballo, con Montesquieu, el P. Feijoo y el Madarin (1965), ou Benito Varela Jácome, con Las preocupaciones literarias del P. Feijoo (1968).

No que resta de século non decaeu demasiado o interese por Feijoo, pois na década dos setenta déronse a coñecer os traballos de Chao Espina (1971-1972, 1974 e 1976), sobre bioloxía ${ }^{62}$; de José Luis Varela (1970), relativo ao xénero do

62 Chao Espina, Enrique (1971-1972): «Feijoo e Sarmiento encol da baleia», Boletín de la Real Academia Gallega, XXXI:353-354, 169-182. 
ensaio $^{63}$, ou o de Xosé Filgueira Valverde (1971), acerca das relacións cos españois americanos ${ }^{64}$. Nos últimos anos salienta a aparición en Galicia dalgúns «expertos» na obra de Feijoo, como foron os casos de Ramón López Vázquez co escolasticismo $^{65}$ (1995) e de Andrés Martínez Lois coa obra filosófica ${ }^{66}$ (Martínez Lois 1992, Martínez Lois 1990a e 1990b).

\section{O SÉCULO XXI}

Inmaculada Urzainqui, na «Introdución» ao Simposio Feijoo hoy. (Semana Marañón 2000), sinalaba que desde o último congreso internacional realizado en Oviedo sobre Feijoo, en 1976 (II Simposio Feijoo y su siglo): «los estudios y la investigación sobre su obra han venido sufriendo un cierto retroceso. Al menos en comparación con otras figuras de la Ilustración que vinieron después como Jovellanos, Forner; Campomanes, etc. que se han beneficiado mucho más del interés y la renovación de estudios sobre el siglo XVIII que se ha vivido en los últimos años».

Esta realidade, constatable na análise bibliométrica, pode ter explicación ben nun certo esgotamento dos temas que suscita o Padre Mestre ben nunha deriva do interese investigador cara a outros obxectivos. De todos os modos, o «tema Feijoo", aínda que atenuado, segue vivo, como o demostra o significativo número de investigacións deste século (34, no repertorio bibliográfico do Instituto Cervantes, que sería máis dun centenar se se extrapolasen con ese mesmo ritmo de publicación ata finais do século XXI).

${ }^{63}$ Varela, José Luis (1970): «El ensayo de Feijoo y la Ciencia», en La transfiguración literaria, Madrid, Prensa Española, 91-146.

64 Ver nota 34.

${ }^{65}$ López Vázquez, Ramón (1995): O Padre Feixoo, escolástico, Santiago de Compostela, Centro de Investigacións Lingüísticas e Literarias Ramón Piñeiro.

${ }^{66}$ Martínez Lois, Andrés (1990a): El padre Feijoo. Naturaleza, hombre y conocimiento, A Coruña, Deputación Provincial; Martínez Lois, Andrés (1990b): «O P. Feijoo: Liñas medulares da gnoseoloxía feixoniana», en Xosé Luís Barreiro Barreiro (coord.), O pensamiento galego na historia, Santiago de Compostela, Universidade, 159-167; Martínez Lois, Andrés (1992): «El Padre Feijoo y la gnoseología: del realismo ingenuo al fenomenalismo perspectivista», Pensamiento, 48:190, 231-243. 
En Galicia, detéctase unha diminución nas contribucións ao estudo de Feijoo, mais, en ningún momento, unha desaparición do interese pola figura do Padre Mestre. Certamente, as achegas dos investigadores galegos aos dous últimos simposios internacionais de Oviedo son nulas, o que se podería interpretar como unha certa incapacidade para acadar o nivel de excelencia que estes eventos esixen. Porén, neste século efectuáronse achegas en Galicia dunha calidade excelente.

Neste senso, poderíase indicar, por exemplo, o esclarecedor estudo de Xosé Ramón Barreiro Fernández sobre as contribucións de Pardo Bazán, Concepción Arenal e Morayta ao Certame sobre Feijoo do ano 1876 ( $\mathrm{O}$ estudio crítico das obras do P. Feijóo, de Pardo Bazán, Concepción Arenal e Miguel Morayta. O certame de Ourense de 1876», 2003); o libro do hispanista Enrique Rodríguez Cepeda, realizado na Universidade de California (L.A.), concernente á bibliografía e á iconografía na obra de Feijoo (De Benito Feijoo a Martín Sarmiento. Bibliografía crítica de la obra de Feijoo, 2008), e a serie de traballos de Luís Rodríguez Ennes relativos ás relacións de Feijoo co Dereito, que culminaron co seu libro El Padre Feijoo y el derecho de su tiempo: una visión premonitoria de problemas de candente actualidad (2013).

Houbo, ademais, importantes traballos de síntese da obra de Feijoo. Entre eles están o de Lozano Paz para a Editorial Bahía (Frei Benito Xerónimo Feixoo, 2002), o Diccionario Enciclopédico do Pensamiento Galego do Consello da Cultura Galega (Feixoo, Benito Xerónimo, 2008) e o de X. Manteiga Pedrales para as dúas edicións da Gran Enciclopedia Galega $(1976,2003)$.

A emigración galega actual, orientada cara a España e Europa e con menores recursos, dispón dunha menor capacidade editora que a americana. A pesar de todo, tampouco esqueceu a figura do Padre Mestre, tal e como amosa o Centro Galego de Xixón coa publicación de F. Mera Álvarez (Padre Feijoo: personajes ilustres, 2009).

Por último, con motivo do 250 aniversario do falecemento do Padre Mestre, o Consello da Cultura Galega realizou un Seminario en Ourense co título B. J. Feijoo. Renovador do pensamiento da Ilustración e o Museo Arqueolóxico desta cidade levou a cabo na súa lembranza unha exposición co título O Padre Feijoo. Cidadán libre da República Literaria. Pola súa parte, no III Congreso Internacional sobre Feijoo (Con la razón y la experiencia. Feijoo 250 años después), realizado en Oviedo polo Instituto Feijoo de Estudios del Siglo XVIII, presentáronse dúas comunicacións de investigadores galegos. 


\section{CONCLUSIÓNS}

A presenza do Padre Feijoo está balizada en Galicia por expresións simbólicas tan sinaladas como as tres estatuas que se ergueron en Ourense, Samos e Allariz; os bustos e retratos conservados en moitas institucións, e as numerosas rúas e prazas que levan a súa lembranza por todo o país. Así mesmo, a abondosa produción bibliográfica no seo da cultura galega denota, dunha parte, a vixencia da figura e a obra do Padre Mestre e, doutra parte, a súa afervoada defensa por parte de nomes senlleiros, como Faraldo, Curros, Murguía, Lamas Carvajal, Pardo Bazán, Castelao, Cabanillas, Otero Pedrayo, Blanco-Amor, Seoane, etc.

Resulta significativa a permanencia do pensamento e da obra na conciencia colectiva dos galegos, aínda que nas zonas de Samos e Ourense resoa con especial insistencia e forza. En especial, a cidade das Burgas foi, sen dúbida, a principal protagonista de manter viva e acesa a memoria do beneditino.

O nacemento en Casdemiro, moi preto da ribeira do Miño ourensán, a formación académica no mosteiro de Samos e as primeiras experiencias educativas en Lérez e Poio foron datos suficientes para ser considerado un dos nosos. Amais disto, a traxectoria como un dos grandes da cultura hispana axudoulle para ter un peso específico e singular na historia cultural de Galicia, esa historia sobre a que se asentou, en boa medida, o seu renacemento como cultura e como «nazón».

Ben é certo, como amosa este repaso da presenza de Feijoo en Galicia, que a súa valoración pasou por moitas vicisitudes. Que tivo o seu máximo esplendor no último terzo do dezanove e que os tempos actuais non semellan ser moi sensibles ás achegas de figuras enciclopédicas e divulgadoras, como foi a do beneditino. En troques, contan máis os persoeiros rutilantes e de fulgores perecedoiros.

Como datos máis relevantes e diferenciais que se poden deducir deste traballo verbo do recoñecemento da obra e da vida do Padre Feijoo en Galicia poderían sinalarse a grande importancia da produción bibliográfica galega do último terzo do XIX e das primeiras décadas do XX dentro do contexto español así como a relevancia da contribución da emigración americana. Moitos destes textos eran traballos menores ditados en moitos casos polos sentimentos máis que a consecuencia de estudos demorados e rigorosos. Aínda que non habería que esquecer a existencia de contribucións importantes e significativas dentro da bibliografía feixoniana. 
O Padre Mestre foi un gran divulgador do coñecemento e loitou toda a vida para desterrar os erros dunha poboación maioritariamente iletrada. Pero tamén defendeu como método discriminatorio entre a verdade e a mentira o peso da experiencia e da razón. Era, pois, unha persoa de argumentos sólidos e ben definidos. E, hoxe en día, cando se está a construír un coñecemento «débil» sobre o anecdótico e virtual, os criterios de peso e as persoas que os defenden seguen a ser máis necesarios ca nunca para poder movernos con seguridade entre o abafante exceso de información e frivolidade que nos asexa. En caso contrario, máis que construír esa idílica sociedade do coñecemento que moitos imaxinan, estariamos a crear unha sociedade da ignorancia. Dunha nova ignorancia. 


\section{APÉNDICE BIBLIOGRÁFICO CON LIBROS E ARTIGOS ESCRITOS SOBRE O P. FEIJOO EN GALICIA OU POR ESCRITORES GALEGOS}

1. Alonso Cortés, Narciso (1932): «Datos genealógicos del P. Feijoo», Boletín de la Comisión Provincial de Monumentos Históricos y Artísticos de Orense, IX:207, 417-424.

2. Alonso Montero, Jesús (1964): «Feijoo y Curros Enríquez», en El P. Feijoo y su siglo. Ponencias y comunicaciones presentadas al Simposio celebrado en la Universidad de Oviedo del 28 de Septiembre al 5 de Octubre de 1964, Oviedo, Universidad de Oviedo, vol. 1, 33-36.

3. AÑón, Francisco (1875): «A Feijoo (poema)», El Heraldo Gallego, II:49, 379-380.

4. Areal, Justo Eliseo (1901): Poesías inéditas del P. Feijoo, Tui, Tip. Regional.

5. Areal, Justo Eliseo (1966): «Estudio-epílogo», en Antología Popular (selecc. e prólogo de Eduardo Blanco-Amor), Bos Aires, Ed. Galicia.

6. Arenal, Concepción (1877): "Juicio crítico de las obras de Feijoo», Revista de España, LV, 110-117, 187-226 e 398-410; LVI, 348-365, e LVII, 174-201.

7. Ares de Parga, I. (1913): «El Padre Feijoo», Suevia, Bos Aires, 8, 7-8.

8. Arias, Maximino (1977): «Catorce cartas de Feijoo al P. Sarmiento (reseña bibl.)», El Progreso, 16-I-1977.

9. ArIas, Plácido (1945): «El P. Feijoo y la Iglesia de Samos», Boletín de la Comisión Provincial de Monumentos Históricos y Artísticos de Lugo, II:14-15, 51-53.

10. ARIAS, Plácido (1946): «¿Dónde estudió la filosofía el P. Feijoo?», Boletín de la Comisión Provincial de Monumentos Históricos y Artísticos de Lugo, II:19, 222-223.

11. Armesto, Victoria (1964): Dos gallegos: Feijóo y Sarmiento, A Coruña, Imp. Moret.

12. Armesto, Victoria (1965): «Entre padres anda el juego», La Estafeta Literaria, 322-323, 106-108.

13. Armesto Ramón, Constantino (1997): «Un galego contemporáneo de Newton destacado divulgador da ciencia», Boletín de Ciencias, X:31, 70-78.

14. Baltar Domínguez, R. (1961): «Estudio preliminar sobre la época y los autores», en Opúsculos médicos gallegos del siglo XVIII, Santiago de Compostela, Editorial Bibliófilos Gallegos.

15. Barreiro Barreiro, Xosé Luís (1996): «Defensa das mulleres e ilustración», en Congreso Internacional de Mujeres e Institución Universitaria en Occidente, Santiago de Compostela, Universidade de Santiago de Compostela, 283-289.

16. Barreiro Barreiro, Xosé Luís (coord.) (1997): Sonos e soños da razón. A Ilustración nas coleccións da Biblioteca Universitaria de Santiago de Compostela. Exposición e simposio Ilustración e educación en Galicia, Santiago de Compostela, Universidade de Santiago de Compostela.

17. Barreiro Fernández, Xosé Ramón (2003): «O estudio crítico das obras do P. Feijóo, de Pardo Bazán, Concepción Arenal e Miguel Morayta. O certame de Ourense de 1876», La Tribuna, I:1, 47-96.

18. Barreiro Fernández, Xosé Ramón (2016): «Ollada crítica sobre a obra de Feijoo de dúas intelectuais galegas: Concepción Arenal e Emilia Pardo Bazán», en Francisco Díaz-Fierros Viqueira (coord.), B. J. Feijoo. Renovador do pensamento da Ilustración, Santiago de Compostela, Consello da Cultura Galega, 53-74.

19. Blanco-Amor, Eduardo (1966): El Padre Feijoo, tema con variaciones, Bos Aires, Ed. Galicia, Centro Galego de Bos Aires.

20. Brocos, Modesto (1930): Viaje a Marte, Valencia, Ed. Artes y Letras. 
21. Calé Torres de Quintero, Emilia (1875): «A Feijoo en el 199 aniversario de su natalicio, celebrado en la Gaceta Literaria (poesía)», El Heraldo Gallego, 47, 362.

22. Canella y Secades, Fermín (1876): «El Padre Feijoo (artículo laudatorio)», El Heraldo Gallego, IV:31, 239-240.

23. Canella y Secades, Fermín (1879): «Un autógrafo del P. Feijoo», La Ilustración Gallega y Asturiana, I: $15,171$.

24. Carballo Calero, Ricardo (1930): «Como vía a Aristóteles o Pai Feijoo?», Arquivos do Seminario de Estudos Galegos, 5, 237-259.

25. Carballo Calero, Ricardo (1964): «Feixó e a Razón Borbónica», Grial, 6, 409-417.

26. Carreras Artau, Tomás e Joaquín (1934): Feijoo y las polémicas lulianas en el siglo XVIII, Santiago de Compostela, reedición.

27. CASARES, Antonio (1876): «Excitación mandada fijar en el tablón de anuncios de aquel centro (Universidad de Santiago) invitando a los alumnos a concurrir al Certamen Literario en honor del P. Feijoo que ha de celebrarse el 8 de octubre de 1876 (Santiago, 4-IV-1876)», El Heraldo Gallego, III:29, 231-232.

28. Casás Fernández, Manuel (1950): «El P. Feijóo juzgado en su tiempo», Boletín de la Real Academia Gallega, XXV:289-293, 3-45.

29. Casás Fernández, Manuel (1951): «El P. Feijóo y la justicia», Boletín de la Real Academia Gallega, XXV:294-296, 191-221.

30. Castro, Cristóbal de (1943): «La Celda de Samos», Finisterre. Revista de Galicia Mensual Ilustrada, I:2, 6.

31. Castro López, Manuel (1923): «Patriotismo del Padre Feijóo», 1923. Almanaque Gallego, Bos Aires, $16,79-86$.

32. Castro Valladares, José (1875): «El nacimiento del P. Feijoo», El Heraldo Gallego, II:41, 313-314.

33. Catorra, Pelayo (1860): «Fr. Benito Gerónimo Feijóo», Galicia. Revista Universal de este Reino, I:5, 76-77.

34. Cernadas de Castro, Diego Antonio (1774): Ofrenda general para las exequias del muy ilustre Rvdo. P. M. Feyjóo, Santiago de Compostela.

35. Chao Espina, Enrique (1965): «Despedida del año feijoniano. El Padre Feijoo en el despertar de la ictiología», Revista General de Marina, CLXVIII, 147-149.

36. Chao Espina, Enrique (1971-1972): «Feijoo e Sarmiento encol da baleia», Boletín de la Real Academia Gallega, XXXI:353-354, 169-182.

37. Chao Espina, Enrique (1974): «La generación “ex ovo" dentro de la zoología feijoniana», Boletín de la Real Academia Gallega, XXXI:356, 3-20.

38. Chao Espina, Enrique (1975): Tres monstruos de los mares gallegos con otros temas marineros y un saludo de Camilo José Cela, Ortigueira, Imp. Fojo.

39. Chao Espina, Enrique (1976): «Los vivíparos y la psicología animal en el P. Feijoo», Boletín de la Real Academia Gallega, XXXII:358, 37-64.

40. Cid, Luciano (1876): «Recuerdo al Padre Maestro Fray Benito Jerónimo Feijoo y Montenegro», El Heraldo Gallego, IV:29, 225-227.

41. Cid RumbaO, Alfredo (1948): «La verdadera patria del P. Feijoo y otras notas inéditas sobre su apellido y su familia", Boletín del Museo Arqueológico de Orense, 4, 3-38.

42. Cidade, Hernâni (1933): «Uma revolução na vida mental da Península no século XVIII (Pe. Benito Feijoo e Pe. Luis Antonio Verney)", Boletín de la Universidad de Santiago de Compostela, Tip. de El Eco Franciscano, V:17, 447-465. 
43. Cidade, Hernâni (1934): «Uma revolução na vida mental da Península no século XVIII (Pe. Benito Feijoo e Pe. Luis Antonio Verney)», Boletín de la Universidad de Santiago de Compostela, Tip. de El Eco Franciscano, VI:20, 2-23.

44. Cotarelo Valledor, Armando (1930): «A Mocedade do P. Feixóo», Nós. Boletín Mensual da Cultura Galega, XII:81, 172-174.

45. Curros Enríquez, Manuel (1876): «A Orense en el aniversario de Feijoo (poema)», en La aldea de Casdemiro. Álbum literario dedicado á la inmortal memoria del ilustre crítico Padre Feijóo, publicado por El Heraldo Gallego con la colaboración de distinguidos escritores, Ourense, Imp. La Propaganda Gallega.

46. Curros Enríquez, Manuel (1880): El Padre Feijoo, loa dramática en un acto y en verso, Ourense, Imp. de Antonio Otero.

47. Curros Enríquez, Manuel: Epitome histórico de la vida de D. Fray Benito Gerónimo Feijoo. M. Gral. de la religión de San Benito, s.l., s.e., s.a.

48. Delgado Capé́ns, Ricardo (1946): «Por los rincones de la historia. Tres ilustres gallegos: un sabio, un pensador y un colonizador (Feijoo, Sarmiento y Salvado)», Spes, 142, 3-5.

49. Díaz-Fierros Viqueira, Francisco (2014): «La ciencia en Feijoo. Consideraciones desde la Hidrología», en Con la razón y la experiencia. Feijoo 250 años después, Oviedo, (en prensa).

50. Díaz-Fierros Viqueira, Francisco (2016): «Presenza do Padre Feijoo en Galicia», en Francisco DíazFierros Viqueira (coord.), B. J. Feijoo. Renovador do pensamento da Ilustración, Santiago de Compostela, Consello da Cultura Galega, 75-115.

51. Domínguez Fontenla, J. (1923-1926): «El P. Feijoo. Segundo Centenario de la publicación del tomo I del Teatro Crítico. Propuesta de su celebración", Boletín de la Comisión Provincial de Monumentos Históricos y Artísticos de Orense, VII, 424-429.

52. Domínguez Fontenla, J. (1932): «El apellido Feijóo. Como debe escribirse», Boletín de la Comisión Provincial de Monumentos Históricos y Artisticos de Orense, IX:207, 424-425.

53. Domínguez Fontenla, J. (1936-1938): «El Padre Feijoo. Sus ideas crítico-filosóficas, Por Sara Leirós», Boletín de la Comisión Provincial de Monumentos Históricos y Artísticos de Orense, 39-40.

54. Eiján Lorenzo, Samuel (1943-1944): «Ideas literarias del P. Feijóo», Boletín de la Real Academia Gallega, XXIIII:271-272, 269-277; 273, 281-297, XXIV:277-280, 35-50.

55. Elías de Tejada SpínOla, Francisco (1944): «Un erudito europeo: Feijoo», en La tradición gallega, Madrid, Gráficas González, 87-92.

56. Faraldo, Antolín (1842): «Filósofos gallegos. Feijoo», El Recreo Compostelano, 3, 30-37.

57. Feijoo Montenegro, Benito Jerónimo (1944): Españoles americanos y otros ensayos, Bos Aires, Ed. Emecé,

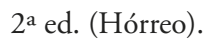

58. Fernández, Modesto (1964): «Homenaje al P. Feijoo en la abadía de Samos con motivo del segundo centenario de la muerte del P. Benito Feijoo", Yermo, II:3, 281-283.

59. Fernández Alonso, Benito (1916): «Padre Feijó», en Orensanos ilustres, Ourense, Imp. de El Diario de Orense, 95-106.

60. Fernández Alonso, Benito (1926): «Notas biográficas del P. Feijoo», La Región, Ourense, 17-X-1926.

61. Fernández García Armesto, Fermín (1965): «Feijoo, el reformador del arte de curar», en Fray Benito Jerónimo Feijoo y Montenegro. Estudios reunidos en conmemoración del IIo Centenario de su muerte (1764-1964), La Plata, Facultad de Humanidades y Ciencias de la Educación, 222-225. 
62. Fernández y González, Modesto (1876): «El Padre Feijoo», El Heraldo Gallego, IV:29, 225-227. Reproducido en La Tierra Gallega (1895), 58, 2-3; 61, 3 e 62, 3.

63. Fernández y González, Modesto (1877): «El Padre Feijoo», La Época, 19-III-1877.

64. Fernández y GonzÁlez, Modesto (1877): «Una expedición a Casdemiro. La casa del P. M.», La Época, 9-IX-1877.

65. Fernández Pousa, Ramón (1964): «Feijoo y Sarmiento», Airiños aires, 3, 11-29.

66. Figueiredo Feal, Manuel (1946?): Contenido pedagógico de la obra del P. Feijoo, A Coruña, Imp. Moret.

67. Filgueira Valverde, Xosé (1965): «La vida del Padre Feijoo», El Museo de Pontevedra, 19, 139-142.

68. Filgueira Valverde, Xosé (1966): «Genio y figura del P. Feijoo», en El Padre Feijoo y su Monasterio de Samos, Samos, Abadía, Publ. da Real Abadía de Samos, II.

69. Filgueira Valverde, Xosé (1971): El Padre Feijoo y los españoles americanos, Pontevedra, Imp. Hogar Provincial, XXI.

70. Filgueira Valverde, Xosé (1992): «América ante dos ilustrados: Feijoo y Sarmiento», en Factores de diferenciación e instancias integradoras en la experiencia del mundo iberomericano. Actas, Madrid, 8 al 14 de noviembre de 1922, 227-248.

71. Gallego Esperanza, Mercedes (2011): «El padre Feijoo: un ilustrado ourensano», Ourense Siglo XXI, $\mathrm{V}: 22,64-67$.

72. Gamallo Fierros, Dionisio (1965): «La poesía de Feijoo», en Juan José Cobo Barquera et al., Ocho ensayos en torno a Feijoo, Santander, Ateneo, 127-177.

73. García Díaz, N. (2014): «Feijoo 250 anos despois», en O Padre Feijoo. Cidadán libre da República Literaria: Catálogo da Exposición, [Santiago de Compostela], Xunta de Galicia, 25-36.

74. García Ferreiro, Alberto (1887): «Las Fiestas del P. Feijóo», Galicia. Revista Regional, I:11, 221-230.

75. García Ferreiro, Alberto (1887): «A Feijoo», Galicia Moderna (A Habana), III:128, 3.

76. Giordano, Jaime (1970): «Feijoo y el género ensayístico», Grial, 30, 409-417.

77. Gobernador de Lugo (1876): «Circular a la Diputación Provincial y Ayuntamientos de la provincia, a fin de que cooperen, como sus recursos lo permitan, a dar esplendor al Certamen Literario que ha de celebrarse en Orense el 8 de octubre de 1876», El Heraldo Gallego, III:15, 118-119.

78. Gómez Pereira, Mauro (1935): Pro Monumento al insigne polígrafo benedictino Padre Feijoo en la Abadía de Samos: España, A Coruña, Imp. Moret.

79. Gómez Pereira, Mauro (1935-1936): «Homenaje a Feijoo, Revista Hispánica Moderna, II, 230.

80. GonzÁlez, Victoriano (1966): El Padre Feijoo y su Monasterio de Samos, Lugo, Tip. La Voz de la Verdad. (Publicaciones de la Real Abadía de Samos; 2).

81. González Crespo, S. (1963): Benito Jerónimo Feyjoo Montenegro y Puga, monje benedictino. En el segundo centenario de su muerte. Discurso inaugural curso 1963-64 en el Seminario Diocesano de Orense.

82. Hermida, José M. (1876): «La casa de Casdemiro», en La Aldea de Casdemiro. Álbum literario dedicado á la inmortal memoria del ilustre crítico Padre Feijóo, publicado por El Heraldo Gallego con la colaboración de distinguidos escritores, Ourense, Imprenta de La Propaganda Gallega.

83. Huertas, D. (1964): «Ante el II Centenario de la muerte del P. Feijoo», La Noche, 5-III-1964.

84. Lamas Carvajal, Valentín (1874): «O nacemento d'o Padre Feixoo», El Heraldo Gallego, I:40, 293.

85. Lamas Carvajal, Valentín (1876): «Galicia en el segundo centenario del Padre Feijoo», en Certamen Literario en conmemoración del Segundo Centenario del Nacimiento de Fray Benito Jerónimo Feijoo, autor del 
Teatro Crítico Universal, celebrado en Orense el 8 de octubre de 1876: obras premiadas, Madrid, Tipografía y estereotipia Perojo.

86. Lamas Carvajal, Valentín (1876): «A Feixoo, el solo gallego (poema)», en La Aldea de Casdemiro. Álbum literario dedicado á la inmortal memoria del ilustre crítico Padre Feijóo, publicado por El Heraldo Gallego con la colaboración de distinguidos escritores, Ourense, Imprenta de La Propaganda Gallega.

87. Lamas CARVAJAL, Valentín (1877): «A Galicia. N'o segundo Centenario d'o nacemento d'o sabeo Feixoo (poema)", en Certamen Literario en conmemoración del Segundo Centenario del Nacimiento de Fray Benito Jerónimo Feijoo, autor del Teatro Crítico Universal, celebrado en Orense el 8 de octubre de 1876: obras premiadas, Madrid, Tipografía y estereotipia Perojo, 175-180.

88. Leirós Fernández, Sara (1935): El P. Feijoo y sus ideas crítico-filosóficas, Santiago de Compostela, Imp. Paredes.

89. Leirós Fernández, Sara (1967): El Padre Feijóo. Su magisterio. Antología de sus obras, Lugo, Imp. La Voz de la Verdad. (Publicaciones de la Real Abadía de Samos; 3 ).

90. López Acuña, Antonio (1938): «El Padre Feijoo y la Biblioteca Provincial», en Historia de la Biblioteca Provincial de Lugo. Fundación, vicisitudes y estado actual, Lugo, Deputación Provincial de Lugo, 33-38.

91. López Peláez, Antolín (1897): «Sarmiento en defensa de Feijóo», Revista Contemporánea (Madrid), XXIII:105, 225-246.

92. López Peláez, Antolín (1899): «Prólogo», en Las poesías del P. Feijoo, Lugo, Tipografía de G. Castro.

93. López Peláez, Antolín (1901): Los escritos de Sarmiento y el siglo de Feijoo, A Coruña, Andrés Martínez Salazar. (Biblioteca Gallega).

94. López VÁzQuez, Ramón (1994): «Fr. Benito J. Feijoo, profesor de filosofía escolástica», Pensamiento, L:198, 457-469.

95. López VázQuez, Ramón (1995): O Padre Feixoo, escolástico, Santiago de Compostela, Centro de Investigacións Lingüísticas e Literarias Ramón Piñeiro.

96. Lozano Paz, Moisés (2002): Frei Benito Xerónimo Feixoo, A Coruña, Baía Edicións. (Baía pensamento; 6).

97. Lozano Paz, Moisés (2008): «Feixoo, Benito Xerónimo», en Andrés Torres Queiruga e Manuel Rivas García (coords.), Dicionario Enciclopedia do Pensamento Galego, Vigo / Santiago de Compostela, Xerais / Consello da Cultura Galega.

98. MACíAS y GaRCíA, Marcelo (1887): Elogio del sabio benedictino Fray Gerónimo Feijoo, A Coruña, Andrés Martínez Salazar. (Biblioteca Gallega; XII).

99. Macías y García, Marcelo (1926): «Feijóo, poeta», Boletín de la Comisión Provincial de Monumentos Históricos y Artísticos de Orense, VII:170, 438-448.

100. Macías y García, Marcelo (1926): «Ortodoxia de Feijoo», Boletín de la Comisión Provincial de Monumentos Históricos y Artísticos de Orense, VII:170, 430-432.

101. Macías y García, Marcelo (1926): "Elogio Ingenioso del P. Feijoo», Boletín de la Comisión Provincial de Monumentos Históricos y Artísticos de Orense, VII:170, 449 ss.

102. MaCías y GarCía, Marcelo (1927-1929): «Discurso pronunciado en el descubrimiento de una lápida en honor del Padre Feijoo", Boletín de la Comisión Provincial de Monumentos Históricos y Artísticos de Orense, VIII, 87-90.

103. MaCías y GarCía, Marcelo (1930-1932): «Romance laudatorio dirigido por Da Ana María Moscoso de Prado al P. Feijoo y carta de este a la autora», Boletín de la Comisión Provincial de Monumentos Históricos y Artísticos de Orense, IX, 324-328. 
104. Manteiga Pedrares, Xosé (1974): «Feijoo y Montenegro, Benito Jerónimo», en Gran Enciclopedia Gallega, Xixón, Silverio Cañada Editor, 11, 209-224.

105. Manteiga Pedrares, Xosé (2003): «Feijoo Montenegro, Frei Benito Jerónimo», en Gran Enciclopedia Galega Silverio Cañada, Lugo / Pontevedra, El Progreso / Diario de Pontevedra, 16, 213-222.

106. Martín Moreno, Antonio (1976): El Padre Feijoo y las ideologias musicales del XVIII en España, Ourense, Instituto de Estudios Orensanos Padre Feijoo.

107. Martín Moreno, Antonio (1976): El Padre Feijoo y la música. Conferencia inaugural del ciclo musical en conmemoración del Tercer Centenario del Padre Feijoo organizado por el Instituto de Estudios Orensanos, Ourense, 1-XII-1976.

108. MartíneZ, G. (1964): «Ciclo de conferencias feijonianas en la Real Abadía de Samos», Studia Monastica, 6, 395-398.

109. Mariño PAZ, Ramón (1991): «Presencia do galego na sociedade galega durante os séculos XVI, XVII e XVIII», Grial, 110, 263-274.

110. Martínez Lois, Andrés (1988): «Galicia y el Padre Feijoo», Revista / Instituto José Cornide de Estudios Coruñeses, XXIV:24, 117-147.

111. Martínez Lois, Andrés (1989): El Padre Feijoo (Naturaleza, hombre y conocimiento), A Coruña, Deputación Provincial da Coruña.

112. MARTínez Lois, Andrés (1990): «O P. Feijoo: Liñas medulares da gnoseoloxía feixoniana», en Xosé Luís Barreiro Barreiro (coord.), O pensamento galego na historia. Aproximación crítica, Santiago de Compostela, Universidade de Santiago de Compostela, 159-167.

113. Martínez Lois, Andrés (1992): «El Padre Feijoo y la gnoseología: del realismo ingenuo al fenomenalismo perspectivista", Pensamiento, XLVIII:190, 231-243.

114. Martínez-Risco y Macías, Sebastián (1973): Las ideas jurídicas del Padre Feijoo, Ourense, Instituto de Estudios Orensanos Padre Feijoo.

115. Mera Álvarez, Felipe (2009): «Padre Feijoo: personajes ilustres», Airiños (Centro Galego de Xixón), 28. 116. Millares Carlo, Agustín (1943): «O gran galego», Saudade. Verba Galega nas Américas, 4, 3-4.

117. Montero Díaz, Santiago (1931): Galicia en el Padre Feijoo (Conferencia), Madrid.

118. Montero Díaz, Santiago (1932): «Las ideas estéticas del Padre Feijóo», Boletín de la Universidad de Santiago de Compostela, IV:15, 3-95.

119. Montero Díaz, Santiago (1935): «A propósito de un libro de Marañón», Boletín de la Universidad de Santiago de Compostela, VII:23, 213-230.

120. Moscoso de Prado, Ana María (1932): «Romance laudatorio dirigido por Da Ana María Moscoso de Prado al P. Feijóo, y carta de éste a la autora / M. Macías», Boletín de la Comisión Provincial de Monumentos Históricos y Artísticos de Orense, IX:203, 324-328.

121. Murguía, Manuel (1862): «Benito Jerónimo Feijoo», en Diccionario de escritores gallegos, Vigo, Juan Compañel. Reeditado en 1876 en La Aldea de Casdemiro. Álbum literario dedicado á la inmortal memoria del ilustre critico Padre Feijóo, publicado por El Heraldo Gallego con la colaboración de distinguidos escritores, Ourense, Imprenta de La Propaganda Gallega.

122. Muruais, J. (1876): «A Feijoo (poema)», en La Aldea de Casdemiro. Álbum literario dedicado á la inmortal memoria del ilustre crítico Padre Feijóo, publicado por El Heraldo Gallego con la colaboración de distinguidos escritores, Ourense, Imprenta de La Propaganda Gallega.

123. Muruais Rodríguez, Jesús (1876): «La muerte de Feijoo», El Heraldo Gallego, IV:48, 375-377. 
124. Nadime, A. (1876): «Una excitación a Galicia», El Heraldo Gallego, III:18, 139-140.

125. Neira de Mosquera, A. (1850): «Estudios literarios. El P. M. Fr. Benito Gerónimo Feijoo», Museo de las Familias, VIII:14, 105-110.

126. Neira de Mosquera, Antonio (1883): «El P. M. Fr. Benito Gerónimo Feijoo», en Album histórico, cientifico y literario de Galicia, Ferrol, El Correo Gallego.

127. NоBOA, E. [1765]: Oración fúnebre en las exequias que en 22 de enero de 1765 celebró el Real Monasterio de S. Julian de Samos a su hijo... Fr. Benito Feijoo, Salamanca, Real Casa de Samos, Imp. Antonio Villargordo y Alcaraz.

128. NúNEz BúA, Xosé (1964): «Feijoo, Sarmiento y el idioma gallego», en Fray Benito Jerónimo Feijoo y Montenegro. Estudios reunidos en conmemoración del II' Centenario de su muerte (1764-1964), La Plata, Facultad de Humanidades y Ciencias de la Educación, 103-126.

129. Núñez Domínguez, Albino (1960): «O mellor amigo do P. Feijoo», Lar (Bos Aires), 304, 41-42.

130. Núñez Domínguez, Albino (1964): «Feijoo a la vista. Desagravio de la profesión literaria», Faro de Vigo, 1-III-1964.

131. Núñez Domínguez, Albino (1964): «Feijoo contra Rousseau», Faro de Vigo, 21-VI-1964.

132. Odriozola, Antonio (1964): Los estudios sobre el padre Feijoo. Recorrido por las ediciones, biografias y trabajos sobre el Padre Feijoo publicados a lo largo de dos siglos, 1764-1964, basado en una bibliografía feijoniana que se inserta al final, Pontevedra.

133. Odriozola, Antonio (1965): "El Magisterio del P. Feijoo en Lérez y Poyo», Diario de Pontevedra, 17-V-1964. Reproducido en El Museo de Pontevedra, XIX, 135-138.

134. Odriozola, Antonio (1965): «Exposición bibliográfica del P. Feijoo (1764-1964)», El Museo de Pontevedra, XIX, 133-158.

135. Ossorio y GaLlardo, Ángel (1926): «Discurso en las fiestas del Centenario de la publicación del tomo I del Teatro Crítico de Feijoo", La Región (Ourense), 19-X-1926.

136. Otero TúNEz, Ramón (1966): «Iconografía del P. Feijoo: esculturas», en El Padre Feijoo y su siglo. Ponencias y comunicaciones presentadas al Simposio celebrado en la Universidad de Oviedo del 28 de septiembre al 5 de octubre de 1964, Oviedo, Universidad de Oviedo, 3, 551-559.

137. Otero Pedrayo, Ramón (1935): «A saudade do P. Mestre», El Pueblo Gallego.

138. Otero Pedrayo, Ramón (1943): «El delirio del Padre Maestro», El Pueblo Gallego.

139. Otero Pedrayo, Ramón [co psedudónimo Santiago de Amaral] (1946): «Vinagre de Solera», Finisterre. Revista de Galicia, Pontevedra, IV:24, 28

140. Otero Pedrayo, Ramón [co pseudónimo Santiago de Amaral] (1946): «La antorcha en la mano», La Noche, 2-II-1946.

141. Otero Pedrayo, Ramón [co pseudónimo Santiago de Amaral] (1946): «El P. Feijoo a través de Concepción Arenal», La Noche.

142. Otero Pedrayo, Ramón (1948): «Lord Bacon y el P. Feijoo. Notas y perspectivas sobre una inalterable amistad», en Homenaje a Walter Starkie, Barcelona, Janés, 293-304.

143. Otero Pedrayo, Ramón (1950): «Información y sentir del P. Feijóo sobre el primer escrito célebre de Rousseau", Cuadernos de Estudios Gallegos, V:15, 147-152.

144. Otero Pedrayo, Ramón (1952): «Fray Benito Jerónimo Feijoo», Aturuxo.

145. Otero Pedrayo, Ramón (1958): «iAdios, Padre Maestro!», La Región. 
146. Otero Pedrayo, Ramón (1960): «Notas sobre las simpatías portuguesas del P. M. Feijoo», en Miscelánea de Estudos a Joaquim de Carvalho, Figueira de Foz, 5, 492-496.

147. Otero Pedrayo, Ramón (1964): «Na procura do íntimo Mestre Feixoo», Grial, 4, 159-168.

148. Otero Pedrayo, Ramón (1964): «Pontevedra y el P. Feijoo», Diario de Pontevdra, 6-II-1964.

149. Otero Pedrayo, Ramón (1964): «La primera estatua del P. Feijoo», La Noche, 10-III-1964.

150. Otero Pedrayo, Ramón (1965): «Coordenadas históricas de la vida del P. Feijoo», en Juan José Cobo Barquera et al., Ocho ensayos en torno a Feijoo, Santander, Ateneo, 199-213.

151. Otero Pedrayo, Ramón (1965): «Estudios sobre Feijoo», Arbor, LX:229, 5-48.

152. Otero Pedrayo, Ramón (1969): Sintesis histórica do século XVIII en Galicia, Vigo, Galaxia.

153. Otero Pedrayo, Ramón (1972): El Padre Feijóo. Su vida, doctrina e influencias, Ourense, Instituto de Estudios Orensanos Padre Feijoo.

154. Otero Pedrayo, Ramón (1972): «Sobre el P. Sarmiento. La defensa del Teatro Crítico», Cuadernos de Estudios Gallegos, XXVII, Santiago de Compostela, 68-73.

155. Otero Pedrayo, Ramón (1977): «Horizonte cultural, científico del Padre Feijoo», en Agustín Fliche e Víctor Martín (dirs.), Historia de la Iglesia. De los orígenes a nuestros días, Valencia, EDICEP, XXI, 471-499.

156. Pardiñas Villalobos Soto y Romero de Caamaño, José (1887): «Feijoo y Sarmiento», en Breve compendio de los varones ilustres de Galicia. Nativos, y próximos originarios, esclarecidos en virtudes, literatura y dignidades eclesiásticas, con algunas cortas relaciones de sucesos particulares, A Coruña, Andrés Martínez. (Biblioteca Gallega).

157. Pardo BazÁn, Emilia (1877): «Examen crítico de las obras del P. Mtro. Fr. Benito Jerónimo Feijoo del Orden de Benedictinos», en Certamen Literario..., Madrid, 17-164.

158. PARdo BAZÁN, Emilia (1877): «Oda a Feijoo», en Certamen Literario en conmemoración del Segundo Centenario del Nacimiento de Fray Benito Jeronimo Feijoo, autor del Teatro Crítico Universal, celebrado en Orense el 8 de octubre de 1876: obras premiadas, Madrid, Tipografía y estereotipia Perojo, 165-173.

159. Pardo BAzÁn, Emilia (1888): Feijoo y su siglo. Discurso presidencial leido en el Certamen literario que para solemnizar la erección de la estatua de Feijoo ha celebrado la ciudad de Orense el día 10 de septiembre de 1887, A Coruña, Imp. de la Casa de la Misericordia, 141-217.

160. Pardo BazÁn, Emilia (1888): «La casa solariega del P. Feijoo», en De mi tierra, A Coruña, Tipografía de la Casa de Misericordia, 219-228.

161. Pardo BazÁn, Emilia (dir.) (1891-1893): Nuevo Teatro Crítico, Madrid, La España Editorial. Public. periódica

162. Pardo BazÁn, Emilia (1926): «La Mascarilla del P. Feijoo», Boletín de la Comisión Provincial de Monumentos Históricos y Artísticos de Orense, VII:170, 433-435.

163. Paz NovoA, Juan Manuel (1876): «Sombra y Sur (poema)», en La aldea de Casdemiro. Álbum literario dedicado á la inmortal memoria del ilustre Padre Feijóo, publicado por El Heraldo Gallego con la colaboración de distinguidos escritores, Ourense, Imp. de La Propaganda Gallega.

164. Pensado Tomé, Xosé Luís (1978): «Feijoo e Sarmiento, dúas vidas sin paralelo», Grial, XVI:60, 129-154.

165. Pérez, Lino (1964): «Realismo y liberalismo del padre Feijóo», Airiños. Revista de la Asociación Casa de Galicia de Buenos Aires, XV:17, 34- 35.

166. Pérez, Narciso (1935): «La celda del P. Feijoo en Samos», Monasticón, 2, 143-154. 
167. Pérez, Narciso (1947): «El Padre Feijoo y las Ciencias Naturales (Un capítulo de historia de la Ciencia española)", Revista de la Real Academia de Ciencias Exactas, Físicas y Naturales, 118-124, 287-337, 467-513 e 599-643.

168. Pérez de Castro, J. L. (1963): «La filosofía polémica de Feijoo», La Región, 13-XI-1963.

169. PiñEIro, Eduardo (1999): «Lembranzas dun ilustrado: Feijoo e Samos», Galicia dende Salamanca, 2, 229-233.

170. PiтA, Emilio (1964): «Feixoo e o Cura de Fruime», Galicia. Revista del Centro Gallego de Buenos Aires, 538, 8-9.

171. Placer Bouzo, Camilo (1874-1875): «El Padre Feijoo», El Heraldo Gallego, I:40, 292 ss.; 41, 257-259; 44, 36-38; 46, 321-324; 49, 353-356, II:8, 60 ss.; 12, 82-85.

172. Placer Bouzo, Camilo (1875): «Recuerdo del P. Feijoo»», El Heraldo Gallego, II, 43.

173. Placer Bouzo, Camilo (1879): «El Almirante Feijóo», La Ilustración Gallega y Asturiana, I:17, 196-197.

174. Presedo Garazo, Antonio (2014): «Os Feijoo y Puga, unha familia da fidalguía provincial ourensá na Galicia dos séculos XVII e XVIII», en O Padre Feijoo. Cidadán libre da República Literaria: Catálogo da Exposición, [Santiago de Compostela], Xunta de Galicia, 17-23.

175. Quiroga, Domingo (1954): Padre Maestro. Ensayos legendarios sobre la Iglesia y Monasterio de San Martín Pinario de Santiago de Compostela, A Coruña, Editorial Moret.

Novela que gañou o Premio Valle Inclán, en 1952, do Centro Galego de Bos Aires.

176. Rey FeÁs Alvite, J. (1946): «Ante la inauguración del monumento del P. Feijoo», La Noche (16-III-1946), 3.

177. Risco, Vicente (1956): «El P. Maestro Fray Benito Feijoo y Montenegro», en Historia General de las Literaturas Hispánicas, Barcelona, Ed. Barna, IV, $1^{\text {a }}$ parte, 203-234.

178. Rodríguez Cepeda, Enrique (2008): De Benito Feijoo a Martín Sarmiento. Bibliografía e inonografia crítica de la obra de Feijoo, Lugo, Deputación Provincial de Lugo.

179. Rodríguez EnNes, Luis (2008): "Arredor da vida e obra do Padre Feijoo», Anuario de la Facultad de Derecho de Ourense, 419-430.

180. Rodríguez EnNes, Luis (2008-2009): «Benito Jerónimo Feijoo», Glaucopis, 14, 9-19.

181. RodríGuez EnNES, Luis (2012): «Benito Jerónimo Feijoo (1676-1764): o monxe ilustrado», en Jesús de Juana López, Julio Prada Rodríguez e Domingo Rodríguez Teijeiro (coords.), Galegos de Ourense, Ourense, Deputación Provincial de Ourense, 53-68.

182. Rodríguez Ennes, Luis (2013): El padre Feijoo y el Derecho de su tiempo: una visión premonitoria de problemas candentes en la actualidad, Madrid, Dykinson. (Monografías de Derecho Romano).

183. Rodríguez EnNes, Luis (2014): «El pensamiento jurídico del padre Feijoo», en Con la razón y la experiencia. Feijoo 250 años después, Oviedo, Universidad de Oviedo, Instituto Feijoo del siglo XVIII (en prensa).

184. Rodríguez Ennes, Luis (2016): «Vixencia actual do pensamiento xurídico-social do Padre Feijoo», en Francisco Díaz-Fierros Viqueira (coord.), B. J. Feijoo. Renovador do pensamento da Ilustración, Santiago de Compostela, Consello da Cultura Galega, 37-52.

185. Rodríguez González, Avelino (2014): «A reivindicación do fillo esclarecido: o Padre Feijoo no século XIX», en O Padre Feijoo. Cidadán libre da República Literaria: Catálogo da Exposición, [Santiago de Compostela], Xunta de Galicia 37-43. 
186. Rodríguez González, Xulio (2014): «Presentación», en O Padre Feijoo. Cidadán libre da República Literaria: Catálogo da Exposición, [Santiago de Compostela], Xunta de Galicia, 13-15.

187. Rof Carballo, Juan (1965): «Medicina crítica y medicina comprensiva en la obra del P. Feijoo», en Juan José Cobo Barquera et al., Ocho ensayos en torno a Feijoo, Santander, Ateneo, 41-70.

188. Rof Carballo, Juan (1965): «Montesquieu, el P. Feijoo y el Mandarín», Cuadernos para el Diálogo, Madrid, 17, 39.

189. Rubinos, José (1936): «La fama de Feijóo en América», Cultura Gallega (A Habana), I:15, 11-12.

190. SACO Y ARCE, Juan A. (1876): «Prólogo», en Certamen Literario en conmemoración del Segundo Centenario del Nacimiento de Fray Benito Jerónimo Feijoo, autor del Teatro Crítico Universal, celebrado en Orense el 8 de octubre de 1876: obras premiadas, Madrid, Tipografía y estereotipia Perojo.

191. SAn Miguel, G. (1934): «La más egregia de las figuras monásticas gallegas. Un estudio de Marañón sobre Las Ideas Biológicas del P. Feijoo", El Ideal Gallego, 18-V-1934, 6.

192. SÁnChez CANTÓN, Francisco Javier (1956): «Estudio preliminar», en Opuisculos gallegos sobre Bellas Artes de los siglos XVII y XVIII: Vega y Verdugo, Domingo de Andrade, P. Feijoo, P. Sarmiento, Felipe de Castro, Prado y Mariño, Santiago de Compostela, Bibliófilos Gallegos.

193. SÁnchez Cantón, Francisco Javier (1961): Ideas de los PP. Feijoo y Sarmiento sobre la organización de los estudios, Oviedo, Universidad, Facultad de Filosofía y Letras. (Cuadernos de la Cátedra Feijóo; 10).

194. SÁnChez GuISANDE, Gumersindo (1965): «El P. Feijoo y los anatomistas españoles de su siglo», en Fray Benito Jerónimo Feijoo y Montenegro Estudios reunidos en conmemoración del II' Centenario de su muerte (1764-1964), La Plata, Facultad de Humanidades y Ciencias de la Educación, 259-277.

195. Serrano Castilla, Francisco (1965): Menéndez Pelayo y el Padre Feijoo. Conferencia pronunciada en 18 de septiembre de 1964 en la Real Abadía de Samos, Santiago de Compostela, Tipografía del Seminario Conciliar.

196. Sarmiento, Martín (1726): Sarmiento contra Lesaca, apología del discurso médico del Theatro Crítico.

197. SARMiento, Martín (1739): Demonstración crítico-apologética del Theatro Critico Universal que dio a luz el R. P. M. Fr. Benito Geronymo Feijoo, Madrid, Imp. Viuda de Francisco del Hierro, 2a imp.

198. Seodne, L. (1965): «El padre feijoo y las artes visuales», en Fray Benito Jerónimo Feijoo y Montenegro. Estudios reunidos en conmemoración del II' Centenario de su muerte (1764-1964), La Plata, Facultad de Humanidades y Ciencias de la Educación, 211-222.

199. Simón DíaZ, José (1948): «Una carta inédita del P. Feijoo», Cuaderno de Estudios Gallegos, IX, 150-151. 200. Soto, José H. (1926): «El Padre Maestro fray Benito Jerónimo Feijoo y Montenegro», Céltiga (Bos Aires), 44, 29-30; 45, 29-30; 46, 31-32.

201. s/s (1875): «iGloria a Feijoo!», El Heraldo Gallego, II:41, 309.

202. s/s (1875): «Convocatoria del Certamen Literario en conmemoración del nacimiento del sabio Padre Feijoo", El Heraldo Gallego, II:50, 102-103.

203. s/s (1876): «Un recuerdo al Padre Feijoo», El Heraldo Gallego, III:20, 153-154.

204. s/s (1876): «[Artículo aclarando a la Redacción de El Diario de Santiago cual es la postura del Heraldo Gallego al Certamen del segundo centenario del nacimiento del P. Feijoo]», El Heraldo Gallego, III:27, 214-215.

205. s/s (1876): «Programa de los festejos con que la Ciudad de Orense celebrará durante los días 7, 8 y 9 de octubre próximo el segundo Centenario del nacimiento del P. M. Fr. Benito Jerónimo Feijoo y Montenegro, formulado por la Comisión General del Centenario», El Heraldo Gallego, IV:23, 179-180. 
206. s/s (1876): «8 de Octubre de 1876», El Heraldo Gallego, tomo IV:29, 221.

207. s/s (1876): «Trascripción de la partida de bautismo del P. Feijoo», El Heraldo Gallego, IV:29, 222.

208. s/s (1887): «Un gallego (sc. Feijoo)», El Libredón, 3-I-1887.

209. s/s (1887): «El P. Feijoo y los jesuitas», El Libredón, 4-I-1887.

210. s/s (1887): Programa de los festejos con que la ciudad de Orense celebra la inauguración del monumento del P. M. Benito Jerónimo Feijoo en los días 7, 8, 9, 10 y 11 de septiembre de 1887, Ourense, Tipografía de Antonio Otero.

211. s/s (1918): «El Padre Feijoo», Centro Gallego, 15-IV-1918.

212. s/s (1923-1926): «Certamen Literario celebrado en Orense, conmemorando esta gloriosa efemérides (bicentenario de la Publicación del Teatro Crítico)", Boletín de la Comisión Provincial de Monumentos Históricos y Artísticos de Orense, VII, 450.

213. s/s (1930-1932): «En honor del P. Feijoo. Una piedra de su casa solariega en Casdemiro servirá de base en el nuevo edificio social del Centro Gallego de Buenos Aires», Boletín de la Comisión Provincial de Monumentos Históricos y Artísticos de Orense, IX, 321-323.

214. s/s (1936): «Pro Monumento al insigne polígrafo P. Feijóo en el Monasterio de Samos», Boletín de la Real Academia Gallega, XXII:261, 248.

215. s/s (1937): «Feijóo», Alma Gallega, nº extraordinario 20º aniversario de Casa de Galicia, 73-74.

216. s/s (1939): «En honor del P. Feijoo. Un monumento en la badía de Samos (Lugo)», Boletín de la Comisión Provincial de Monumentos Históricos y Artísticos de Orense, XI (III-IV-1939), 39.

217. s/s (1944): «Nota sobre o P. Feixóo», Saudade. Verba Galega nas Américas, 5, 18.

218. s/s (1947): «Conferencia del Dr. Otero Pedrayo en la universidad de Montevideo. Las tres polémicas esenciales del Padre Feijoo (síntesis)», Alma Gallega, 47.

219. s/s (1947): Laudes Hincmari. En la inauguración del Monumento erigido al P. Benito Jerónimo Feijoo, los monjes benedictinos de S. Julián de Samos cantaron estas Aclamaciones festivas, especialmente adaptadas a tal celebración. Día XXIV-VIII-MCMXLVII, Monserrat.

220. s/s (1908): «Pensamientos», P. Feijoo, Aires d’a miña terra, 2.

221. Suárez Picallo, Ramón (1943): «El Padre Feijóo», La Hora (Santiago de Chile), 8-III-194.

222. Suárez Picallo, Ramón (1950): «El Padre Feijóo», La Hora (Santiago de Chile), 31-III-1950.

223. TABOADA, N. (1887): «Centenario de Feijoo», La Iberia, 11-IX-1887.

224. URZAINQUI, Inmaculada (2016): “Veritas temporis filia”: a achega de Feijoo á historia cultural», en Francisco Díaz-Fierros Viqueira (coord.), B. J. Feijoo. Renovador do pensamento da Ilustración, Santiago de Compostela, Consello da Cultura Galega, 13-35.

225. Valbuena Prat, A. (1947): Feijoo y su época, Santiago de Compostela.

226. Valdés Costas, Manuel F. (1959): «El padre Feijoo y el benedictino tudense Fray Mauro Piñeiro y Falcón», Compostellanum, IV:4, 221-227 e 605-611.

227. Valle Ruiz, R. (1888): «La verdad inspiradora de Feijoo. Canto premiado en el Certamen celebrado en Orense al inaugurar la estatua de Mtro. Feijoo", La Ciudad de Dios. Revista Religiosa, Científica y Literaria, 15, 47-52.

228. Varela, José Luis (1966): «La 'literatura mixta’ como antecedente del ensayo feijoniano», en El Padre Feijoo y su siglo. Ponencias y Comunicaciones presentadas al Simposio celebrado en la Universidad de Oviedo del 28 de septiembre al 5 de octubre de 1964, Oviedo, Facultad de Filosofía y Letras, Cuadernos de la Cátedra Feijoo, 18:I, 79-88. 
229. VArela, José Luis (1965-1967): «Feijoo y la ciencia», en Homenaje al Excmo. Sr. D. Emilio Alarcos García, 2, Valladolid, Universidad, Facultad de Filosofía y Letras, 495-530.

230. Varela, José Luis (1967): "Galicia y Feijoo», en La palabra y la llama, Madrid, Prensa Española, 7 , 205-220. (Vislumbres).

231. Varela, José Luis (1970): «El ensayo de Feijoo y la ciencia», en La transfiguración literaria, Madrid, Prensa Española, 91-146.

232. Varela JÁcome, Benito (1947): «El P. Feijoo, defensor de la cultura gallega», El Correo Gallego, 20-VIII-1947.

233. Varela Jácome, Benito (1947): «El estilo de Feijoo», El Progreso (Lugo), 24-VIII-1947.

234. Varela Jácome, Benito (1964): Feijoo y la crítica (ciclo de conferencias en Samos, 13-20 setembro de 1964).

235. Varela JÁcome, Benito (1968): «Las preocupaciones literarias del P. Feijoo», Cuadernos de Estudios Gallegos, XXIII:70, 155-174.

236. VÁzQuez, Arturo (1881): «Poesías inéditas del P. Feijoo», La Ilustración Gallega y Asturiana, III:7, 80, 92, 128, 140 e 152 .

237. VÁzquez Janeiro, Isaac (1926): «Fr. Francisco Soto Marne, impugnador de Feijoo», Boletín Auriense, IV:4, 167-168.

238. VÁzQuez Pardo, E. (1926): «La Mascarilla del P. Feijoo», Boletín de la Comisión Provincial de Monumentos Históricos y Artísticos de Orense, VII:170, 433-435.

239. Vázquez Seijas, M. (1958-1959): «Transcripción de la Carta de Fr. Benito Feijoo a la muy moble y muy leal Ciudad de Lugo encareciendo noticias para su tomo $5^{\circ}$ del Teatro Crítico", Boletín de la Comisión Provincial de Monumentos Históricos y Artísticos de Lugo, VI:49-52, 295-296.

240. Vergés, A. (1964): «La Semana de Samos (sobre la Semana de Estudios Monásticos dedicada a Feijoo)», Yermo, II: $1,74$.

241. Vesteiro Torres, Teodosio (1876): «Amor y saber», El Heraldo Gallego, IV:31, 240-241.

242. Vesteiro Torres, Teodosio (1879): Galería de Gallegos Ilustres, Lugo, VI, apéndice. Reproducido en Galicia. Revista Semanal Ilustrada (A Habana), I:21 (1902), 1-2.

243. Vicenti, A. (1880): «El P. Feijoo. Recuerdos del segundo centenario de su natalicio», La Ilustración Gallega y Asturiana, II:28, 352 ss.

244. Vilanova, Alberto (1965): «La galleguidad de Feijoo. Fray Benito Jerónimo Feijoo y Montenegro», en Fray Benito Jerónimo Feijoo y Montenegro. Estudios reunidos en conmemoración del II Centenario de su muerte (1764-1964), La Plata, Facultad de Humanidades y Ciencias de la Educación, 69-102.

245. VV. AA. (1876): La Aldea de Casdemiro. Álbum literario dedicado á la inmortal memoria del ilustre crítico Padre Feijóo, publicado por El Heraldo Gallego con la colaboración de distinguidos escritores, Ourense, Imprenta de La Propaganda Gallega.

246. VV. AA. (1877): Certamen literario en conmemoración del segundo centenario del Nacimiento de Fray Benito Gerónimo Feijoo, autor del "Teatro Crítico Universal», celebrado en Orense el 8 de octubre de 1876, Madrid, Perojo.

247. VV. AA. La Real Abadía de Samos organizó entre el 13 y 20 de septiembre de 1964 el siguiente ciclo de conferencias. Cf. Yermo, II:3 (1964), 281-283. (VArela Jácome, B. Feijoo y la crítica; GonZÁlez Martínez, V. El P. Feijoo y su monasterio de Samos; Filgueira Valverde, X. Genio y figura del P. Feijoo; Santos, D. El 
P. Feijoo en la España de hoy; Fernández Pousa, R. Feijoo y Sarmiento; Serrano Castilla, F. Menéndez Pelayo y el P. Feijoo; Torrente Ballester, G. España, la verdad y el P. Feijoo).

248. VV. AA. La XVI Semana de Estudios Monásticos, celebrada en Samos del 20 al 24 de septiembre de 1976, versó sobre El Padre Feijoo y la Ilustración en el monacato hispano del siglo XVIII. Son destacables las siguientes intervenciones: ArIas, M. Catorce cartas inéditas del P. Feijoo al P. Sarmiento; Carro Otero, J. Análisis antropológico-somático del P. Feijoo; CerRa SuÁreZ, S. Feijoo y la antropología de la Ilustración considerados desde la crisis de antropólogica actual; Hevia Ballina, A. El P. Feijoo desde su Biblioteca. Sus aficiones histórico-geográficas; LiNAJE CONDE, A. Entre el sentimiento barroco y la razón neoclásica. Un trio de monjes: Caramuel, Sarmiento, Feijoo; Martínez, M. Una carta inédita del P. Feijoo; Odriozola Pietas, A. Varia fortuna editorial de la obra del P. Feijoo; PéRez De URbel, J. Feijoo, el hombre y el religioso; Regal, B. Monacato y sociedad en la Galicia del s. XVIII). 


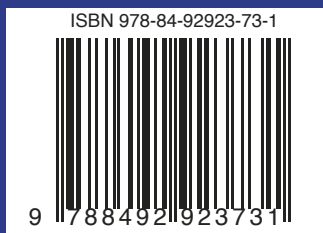

Galicia e, nomeadamente, a cidade de Ourense distinguíronse dun xeito moi singular por espallar por todo o país o pensamento do bieito ilustrado, ata o punto de que na segunda metade do xIx as publicacións galegas superaron en importancia as do resto de España. A figura de Feijoo foi aclamada e a súa galeguidade converteuse en motivo de orgullo e satisfacción para unha Galicia que comezaba a desangrarse nunha riada humana sen fin cara ao alén mar. Esta corrente de afecto mantívose, cando menos, ata a segunda metade do século xx, na que outras efemérides vitais do beneditino serviron como xustificación para realizar novos estudos sobre o seu pensamento e a súa importancia no contexto cultural español. De todas as maneiras, no último cuarto do século xx e na primeira década do xxı comezou a caer nun lento e progresivo esquecemento, e foron moi escasos os traballos ou mencións que lle foron dedicados pola intelectualidade galega.

Feijoo, a pesar de todo, segue a ser unha figura esencial e indiscutible da nosa historia cultural que está por riba das modas e dos oportunismos intelectuais do momento. Por iso, o Consello da Cultura Galega non quixo deixar pasar os douscentos cincuenta anos do seu pasamento, en 1764 , sen lle lembrar á cidadanía galega que o erudito ourensán segue a ser un dos máximos referentes da nosa cultura, como recoñeceu Castelao na "Alba de Groria» incluíndoo no cortexo dos galegos egrexios e inmorredoiros.

Deste xeito, quérese contribuír ao avivamento entre nós da memoria dun galego, referente fundamental da llustración española e loitador incansable contra o pensamento débil, preguizoso e lixeiro. Algo que nunca deixará de estar de actualidade.

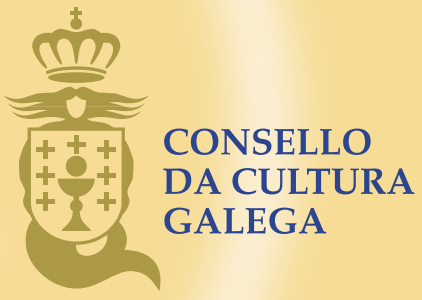

